\title{
DESTRUCTIVE CREATION AT WORK: HOW FINANCIAL DISTRESS SPURS ENTREPRENEURSHIP
}

\author{
Tetyana Babina
}

A dissertation submitted to the faculty of the University of North Carolina at Chapel Hill in partial fulfillment of the requirements for the degree of Doctor of Philosophy in the School of Business.

\section{Chapel Hill}

2016

Approved by:

Geoffrey Tate

Paige Parker Ouimet

Anil Shivdasani

Mahka Moeen

Paolo Fulghieri

Christian Lundblad 
(C) 2016

Tetyana Babina ALL RIGHTS RESERVED 


\section{ABSTRACT \\ TETYANA BABINA: Destructive Creation at Work: \\ How Financial Distress Spurs Entrepreneurship. \\ (Under the direction of Geoffrey Tate)}

Why do employees become entrepreneurs? This dissertation shows that firm financial distress drives the exit of workers to pursue entrepreneurship. In a difference-in-difference setting, I find that, following unexpected industry shocks, employees at relatively more financially levered public firms are more likely to exit to found new firms. These new firms are likely created because financially distressed firms are less able to retain productive workers who exit to found start-ups. Entrepreneurs exiting financially distressed employers earn higher wages prior to leaving paid employment and after founding start-ups, as compared to entrepreneurs exiting non-distressed firms. Consistent with financial distress driving productive workers into entrepreneurship, startups created following financial distress have high future employment growth. Distressed firms are less able to retain entrepreneurial workers in part because ex ante contracts restricting employee mobility are not enforceable. In support of this argument, I find that the effect is concentrated in states with weaker enforcement of non-compete agreements. The results suggest that the social costs of distress might be lower than the private costs to financially distressed firms. 
To David for bringing happiness into my life and to my mama Larisa and sister Nata for their love and support. 


\section{ACKNOWLEDGMENTS}

I thank my advisers Geoffrey Tate, Paige Ouimet, and Anil Shivdasani for the valuable suggestions and support. I also thank Rajshree Agarwal, David Dicks, Paolo Fulghieri, Chris Lundblad, Andrew Karolyi, Camelia Kuhnen, Mahka Moeen, Rebecca Zarutskie, as well as finance faculty and $\mathrm{PhD}$ students at the University of North Carolina-Chapel Hill. I am thankful to Danielle Sandler for her assistance with the data clearance requests.

Any opinions and conclusions expressed herein are those of the author and do not necessarily represent the views of the U.S. Census Bureau. All results have been reviewed to ensure that no confidential information is disclosed. This research uses data from the Census Bureau's LEHD Program, which was partially supported by the following National Science Foundation Grants SES-9978093, SES-0339191 and ITR-0427889; National Institute on Aging Grant A G018854; and grants from the Alfred P. Sloan Foundation. 
TABLE OF CONTENTS

LIST OF TABLES $\ldots \ldots \ldots \ldots \ldots \ldots \ldots \ldots \ldots \ldots \ldots \ldots$ vii

LIST OF FIGURES $\ldots \ldots \ldots \ldots \ldots \ldots \ldots \ldots \ldots \ldots \ldots \ldots \ldots$

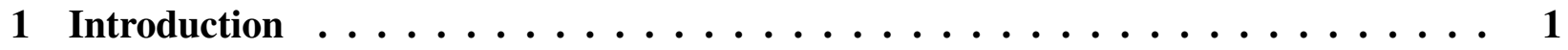

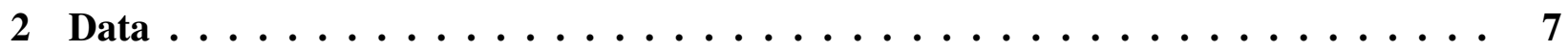

2.1 Data Sources and Sample Selection . . . . . . . . . . . . . . . . 7

2.2 Empirical Methodology . . . . . . . . . . . . . . . . . . . . 11

2.3 Summary Statistics $\ldots \ldots \ldots \ldots \ldots$

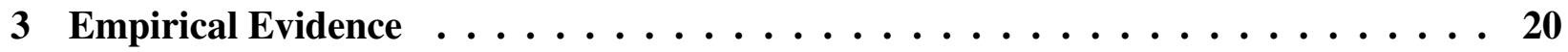

3.1 The Effect of Financial Distress on the Quantity of Worker Entrepreneurship . . . 20

3.2 The Effect of Financial Distress on the Quality of Entrepreneurship . . . . . . . . 32

3.3 Robustness Checks and Interpretation $\ldots \ldots \ldots . \ldots . \ldots . \ldots 42$

3.4 External Validity $\ldots \ldots \ldots \ldots \ldots \ldots \ldots \ldots$

4 Potential Channels $\ldots \ldots \ldots \ldots \ldots \ldots \ldots \ldots \ldots \ldots \ldots \ldots$

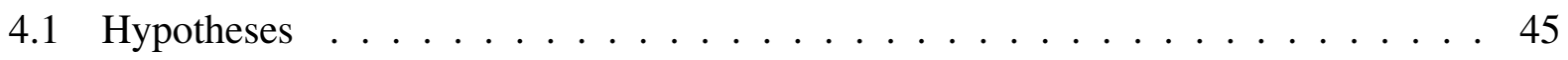

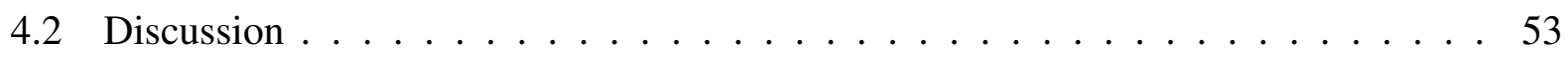

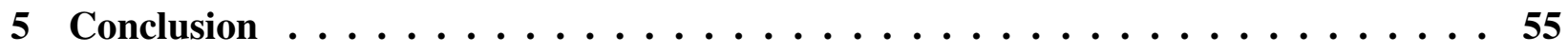

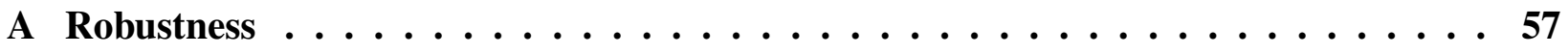

B Variable Definition ......................... 67

BIBLIOGRAPHY $\ldots \ldots \ldots \ldots \ldots \ldots \ldots \ldots \ldots \ldots \ldots \ldots$ 


\section{LIST OF TABLES}

2.1 Summary Statistics: Ex Ante Establishment and Parent Firm Characteristics . . . . 18

2.2 Summary Statistics: Ex Post Worker Entrepreneurship . . . . . . . . . . . . . . 19

3.1 The Effect of Firm Financial Distress on the Rate of Worker Entrepreneurship . . . 28

3.2 The Effect of Firm Financial Distress on the Rate of Worker Entrepreneurship: Alternative Definitions of Worker Entrepreneurship . . . . . . . . . . . . . . 29

3.3 The Effect of Firm Financial Distress on the Rate of Entrepreneurship Among Departing Workers ........................ 30

3.4 Worker Turnover in Financially Distressed Firms _ . . . . . . . . . . . . . . . 31

3.5 The Effect of Firm Financial Distress on the Rate of Entrepreneurship Within the Top Half and the Bottom Half of Wage Earners . . . . . . . . . . . . . . . . 37

3.6 Summary Statistics: Workers Who Become Entrepreneurs . . . . . . . . . . . . 38

3.7 Summary Statistics: Startups Founded by Former Workers ～. . . . . . . . . . . . 39

3.8 The Effect of Firm Financial Distress on the Quality of Entrepreneurs _ . . . . . 40

3.9 The Effect of Firm Financial Distress on the Quality of Startups ～. . . . . . . . . . 41

4.1 The Enforceability of Non-compete Agreements and Worker Departures to Entrepreneurship from Financially Distressed Firms . . . . . . . . . . . . 50

4.2 The Effect of Firm Financial Constraints on the Ability of Firms to Retain Entrepreneurial Workers . . . . . . . . . . . . . . . 51

A.1 The Effect of Firm Financial Distress on Establishment Employment Growth . . 57

A.2 Does Economic, not Financial, Distress Drive Entrepreneurship in Distressed Firms? 58

A.3 The Effect of Firm Financial Distress on the Rate of Entrepreneurship Identified with Firm Fixed Effects . . . . . . . . . . . . . . . . . . . . . . . 59

A.4 The Effect of Firm Financial Distress on the Rate of Entrepreneurship Among Departing Workers . . . . . . . . . . . . . . . 60

A.5 Entrepreneurship in Economically Significant Industries and Controlling for FirmInitiated Spin-outs . . . . . . . . . . . . . . . . . . . . . . 61 
A.6 Alternative Definitions of Financial Leverage . . . . . . . . . . . . . . 62

A.7 The Effect of Firm Financial Distress on the Quality of Entrepreneurs: Report Worker Controls . . . . . . . . . . . . . . . . . . . 63

A.8 The Effect of Firm Financial Distress on the Quality of Startups: Report All Controls 64

A.9 Startup Characteristics as a Function of the Spawning Firm Financial Distress . . . 65

A.10 The Effect of Firm Financial Distress on the Rate of Worker Entrepreneurship in Low Startup Capital Industries and High Tech Industries . . . . . . . . . . . . 66 


\section{LIST OF FIGURES}

2.1 Timeline . . . . . . . . . . . . . . . . . . . . . . 17

3.1 Predicted Entrepreneurship as a Function of Firm Financial Leverage After Distress vs. Non-Distress Industry Years . . . . . . . . . . . . . . . . . . 27 


\section{CHAPTER 1: INTRODUCTION}

Why do people start new firms? Why don't they implement their entrepreneurial ideas within existing firms? These questions are particularly important, given that many successful firms are founded by workers who leave paid employment. ${ }^{1}$ Yet, little is known about when and why workers leave their employer to become entrepreneurs. This dissertation examines one particular period in a firm's existence when it is less likely to be able to retain entrepreneurial workers: during firm financial distress. While a growing empirical literature studies the effects of firm financial distress on workers, whether firm financial distress affects new firm creation is an open question. This dissertation shows that firm financial distress increases the likelihood of workers exiting to found new firms, spurring entrepreneurial activity.

Frictionless markets obviate the need for new firms because economic activity can be carried out within already existing firms. Frictions, however, can lead to new firm creation and financial distress can exacerbate those frictions (Williamson (1975); Grossman and Hart (1986)). Financial distress makes contracting more difficult, since firms in distress have poor incentives to honor contracts (Maksimovic and Titman (1991)). Contracting difficulties and job insecurity might prompt productive workers with ideas for new products or services to leave employment to found new firms (Lucas (1978)). Alternatively, firm financial distress can increase the number of start-ups founded by laid-off workers perceived as low quality by other firms (Gibbons and Katz (1991)).

To test these theories, I define firm financial distress as occurring when a firm with high ex ante financial leverage is hit by a large, unexpected, negative industry-wide shock (Opler and Titman

\footnotetext{
${ }^{1}$ Bhide (2000) reports that $71 \%$ of firm founders in the Inc. 500 (a list of the fastest-growing privately held firms in the U.S.) claim that they had replicated or modified an idea that they had identified in previous employment, compared with only $4 \%$ who had found their idea through systematic search.
} 
(1994)). ${ }^{2}$ A levered firm hit by a shock has to pay debt holders out of its sparse cash flows. Those payments reduce the resources available for the firm to fulfill implicit obligations, such as investing in workers' ideas, thus making the firm a less attractive employer to entrepreneurial workers. Additionally, large shocks increase bankruptcy risk and decrease job security in firms with larger ex ante debt burdens. Consistent with the existing literature that finds lower employment growth in financially distressed firms, I find that relatively more levered firms have lower future employment growth following industry shocks.

To estimate the effect of firm financial distress on entrepreneurship, I use U.S. Census employeremployee matched panel data. Specifically, I measure the propensity of workers at public firms to transition into start-ups. At each establishment of a given public firm, I calculate the percentage of workers who exit and found start-ups within two years after the firm's exposure to a shock. Using this establishment-level entrepreneurship panel, I estimate a difference-in-difference model while including industry-year and establishment fixed effects. I find that following firm financial distress, employees are significantly more likely to exit to found start-ups. A one standard deviation increase in ex ante financial leverage increases the post-shock entrepreneurship rate by $25 \%$ from the mean entrepreneurship rate of $1.5 \%$ to $1.9 \%$. I also document that neither industry distress itself nor elevated firm leverage prior to normal, non-distress industry conditions is associated with higher exit rates of workers into entrepreneurship. This result suggests that both are needed to have an effect on firms' retention of entrepreneurial workers.

The identification strategy described above has several advantages. First, the difference-indifference strategy identifies the effect of firm financial distress on entrepreneurship by measuring the incremental effect of the shock on relatively more levered firms. The inclusion of leverage and industry shock variables control for the general effects of leverage and industry shocks on entrepreneurship. Second, the inclusion of industry-year fixed effects isolates the effect of firm financial leverage on workers who otherwise face the same industry conditions, and hence face the

\footnotetext{
${ }^{2}$ An industry shock is defined based on negative industry sales growth to identify cash flow shock and based on a large negative industry stock return to ensure that the shock is unanticipated.
} 
same job opportunities and incentives to found firms. Last, adding establishment fixed effects addresses additional concerns associated with unobservable, time-invariant heterogeneity that might correlate with both firm leverage and worker entrepreneurship, such as differences in workforce risk tolerance.

I next examine the robustness of the results to some additional concerns. The difference-indifference identification strategy requires that financially distressed firms do not experience differential trends in entrepreneurship prior to the shock. I find no evidence of an increase in entrepreneurship leading up to financial distress. Additionally, the estimates do not change when I include time-varying firm-level variables, such as profitability and Tobin's Q, and establishmentlevel variables, such as proxies for mean worker risk aversion and wealth. The stability of the coefficients helps to mitigate the concern that time-varying omitted factors drive both leverage and entrepreneurship. Moreover, the estimates remain stable when I include state-year fixed effects, reducing the possibility that regional shocks drive changes in leverage and worker entrepreneurship. Finally, the increase in entrepreneurship might be due to higher worker turnover in financially distressed firms. When I re-normalize the count of entrepreneurs by the number of departing employees to directly control for overall turnover, I again find that departing workers are more likely to found start-ups after firm financial distress.

Having established that firm financial distress spurs worker movement to start-ups, I examine whether it changes the quality of entrepreneurship as the first step to testing the mechanisms behind the main findings. While I am unable to observe whether start-up founders quit or were laid off, I do explore whether high- or low-quality workers are responsible for the new firms. If the increase is driven by laid-off workers, we might observe a decline in the average quality of entrepreneurs and the firms they found. Generally, layoffs are more common among lower quality workers (Gibbons and Katz (1991)), and start-ups of laid-off workers are less likely to create jobs or survive (Parker (2009); Pfeiffer and Reize (2000)). Conversely, if the increase is driven by voluntary exits, entrepreneur quality might increase with firm financial distress. Distressed firms are likely less able to retain productive workers, who are also more likely to choose entrepreneurship (Lucas (1978)). 
Using earnings to proxy for worker quality, several findings suggest that workers who transition into entrepreneurship during financial distress are high-quality workers. First, within establishments of financially distressed firms, the exit of workers to found start-ups is more pronounced among higher wage earners. Second, entrepreneurs from financially distressed firms earn higher wages prior to departure and after joining start-ups than entrepreneurs from non-distressed firms. Moreover, the start-ups of entrepreneurs exiting financially distressed employers have higher future employment growth, but similar survival rates to the start-ups of entrepreneurs from non-distressed firms. These results favor the interpretation that the departure of workers from distressed firms to found new firms is driven by voluntary exits of high quality workers, and not by workers who are laid off.

What makes high-quality workers at financially distressed firms exit to found new firms? Both contracting and financing frictions are likely important. Workers might not want to deal with a financially distressed employer that has poor incentives to honor its contracts (Titman (1984); Maksimovic and Titman (1991)). Such a firm might also be less able to access external capital markets and face financing constraints to retain entrepreneurial workers. A worker with ideas for new products or services might be less willing to develop them within a financially distressed firm and be particularly inclined to leave, causing a "brain drain".

For the "brain drain" hypothesis to hold, one must assume that firms in financial distress do not have ex ante contractual means to discourage their workers from starting competing new firms. This assumption is likely relevant, since I find that the entrepreneurs from financially distressed firms are not more likely to switch industries. One of the standard ways to hold onto workers is through non-compete agreements, which restrict employee mobility into competing firms, existing or new. While non-compete agreements are commonplace in all US states, there is significant interstate variation in the degree of their enforcement. If a financially distressed employer is less able to enforce these ex ante contracts, then workers should be more likely to leave to found start-ups. Indeed, I find that the increase in entrepreneurship spawned from distressed firms is concentrated in states with less strict enforcement of non-compete agreements, suggesting that distressed firms 
are less able to retain entrepreneurial workers.

Another assumption underlying the "brain drain" hypothesis is that financially distressed firms are less able to access external capital markets, and hence less able to retain productive workers. Thus, I look at a subset of firms that are particularly likely to have limited access to external capital: small and young firms. I test whether entrepreneurship rates are higher in smaller and younger financially distressed firms. I find that the treatment effect is higher in these firms, suggesting that financing constraints weaken a firm's ability to retain entrepreneurial workers.

Overall, my results suggest that corporate financial distress triggers worker exit to pursue entrepreneurship. Financial distress destroys firm-worker ties, propelling workers to create their own firms as a way to seek better opportunities. This "destructive creation" suggests that some new firms arise when existing firms, weakened by debt during shocks, are less able to retain entrepreneurial workers. While worker entrepreneurship does not likely benefit distressed firms, the findings suggest a silver lining to distress. Productive workers from financially distressed firms start successful new ventures at a higher rate, suggesting that productive resources get reallocated from old to new firms and that the social costs of financial distress might be lower than the private costs to financially distressed firms.

By providing direct evidence that financially distressed firms experience a "brain drain" of productive workers into new firms, this dissertation contributes to the literature on indirect costs of distress. Despite large tax and other benefits of debt, firms seem to be reluctant to use debt financing (Graham (2000)). It has long been proposed that indirect costs of distress explain the under-leverage phenomenon (Titman (1984)). A growing literature argues that part of the indirect costs is borne by workers, discouraging firms from using debt (Berk, Stanton, and Zechner (2010)). Distressed firms reduce wages (Benmelech, Bergman, and Enriquez (2012), Graham, Kim, Li, and Qiu (2015)) and downsize their workforces (Hotchkiss (1995); Agrawal and Matsa (2013)). These costs might negatively affect a firm's ability to attract and retain human capital. Brown and Matsa (2012) show that distressed employers face reduced labor supply from outside workers. ${ }^{3}$ This

\footnotetext{
${ }^{3}$ In addition to the labor market effects, distress may affect firm performance (Opler and Titman (1994); Andrade
} 
dissertation shows that firms might be reluctant to use debt financing to avoid losing productive workers to competing new firms during financial distress.

This dissertation is also related to the literature on "entrepreneurial spawning". Gompers, Lerner, and Scharfstein (2005) find that venture capital-backed, young, and focused firms, as well as firms in California and Massachusetts, have higher employee entrepreneurship. Other papers studying the decision of workers to leave their employers and pursue entrepreneurship include Anton and Yao (1995); Gromb and Scharfstein (2002); Hellmann (2002, 2007); Burton, Sorensen, and Beckman (2002); Stuart and Sorenson (2003); Klepper and Sleeper (2005); Carnahan, Agarwal, and Campbell (2012). This dissertation is the first to show that financial leverage of existing firms affects "entrepreneurial spawning". More broadly, this dissertation is connected to empirical work on the boundaries of the firm (e.g., Robinson (2008); Seru (2014); Bernstein (2015)).

By showing that entrepreneurship in financially distressed firms is higher in smaller and younger firms, this dissertation also provides a novel explanation for why those firms spawn more start-ups. The existing literature argues that preference sorting plays a major role in generating the small and young firm effect; i.e., small and young firms attract workers with prior preferences for autonomy, who are similarly drawn into entrepreneurship (Elfenbein, Hamilton, and Zenger (2010); Ouimet and Zarutskie (2014)). However, an alternate finance-oriented explanation centers around the finding that younger firms are more financially levered than public firms (Robb and Robinson (2014)). This higher leverage makes smaller, younger firms more vulnerable to shocks and less able to retain entrepreneurial employees.

The rest of the dissertation proceeds as follows. Chapter 2 describes the data and the empirical strategy. Chapter 3 provides the main results, 4 discusses potential channels, and 5 concludes.

and Kaplan (1998)); real asset prices (Pulvino (1998)); competitors' collateral values (Benmelech and Bergman (2011)); and how firms compete in product markets, including entry (Chevalier (1995a)), exit (Kovenock and Phillips (1997); Zingales (1998)), pricing (Chevalier (1995b); Phillips (1995); Chevalier and Scharfstein (1996)), product quality (Rose (1990); Borenstein and Rose (2003); Matsa (2011); Phillips and Sertsios (2013)), and product prices (Hortaçsu, Matvos, Syverson, and Venkataraman (2013)). 


\section{CHAPTER 2: DATA}

\subsection{Data Sources and Sample Selection}

I use firm-, establishment-, and worker-level data from the U.S. Census Bureau, and firm- and industry segment-level data from the Compustat/CRSP databases. The U.S. Census Bureau's Longitudinal Business Database (LBD) provides information on firm age, diversification, employment, and survival, as well as on the industry and geography of firms' establishments. The U.S. Census Bureau's Longitudinal Employer-Household Dynamics (LEHD) database provides worker-level data. I use the Compustat Fundamental Annual Database to obtain information on firm-level variables, CRSP to obtain stock return information, and Compustat Business Segment files to obtain sales of firms' industry segments.

\section{Establishment- and Worker-level Data}

The LBD is an annual panel data set that covers all U.S. business establishments with paid employees beginning in 1976. The data are derived from the register of establishments maintained by the Internal Revenue Service of the U.S. Treasury Department. An establishment is a single physical location where business is conducted (Jarmin and Miranda (2002)). The LBD assigns each establishment a unique identifier that allows researchers to track the establishment through time, as well as a firm-level identifier to aggregate information to the firm level and track firms through time. Information is available on industry, physical location, total employment, and payroll along with establishments' births and closures. Thus, the LBD allows the identification of start-ups among employer firms as well as start-ups' future employment growth and exit.

I use the LBD to identify firms and to measure firm age. Age is available only at the establishment level and a firm may consist of many establishments. For that reason, I follow the approach taken in the literature and define firm age as equal to the age of the oldest establishment that the firm owns in the first year the firm is observed in the LBD (Haltiwanger, Jarmin, and Miranda (2012)). 
This definition of firm age is robust to misclassifying an establishment that changes ownership through mergers and acquisitions as a firm birth, since a firm is defined as new only when all of its establishments are new. Since the LBD only covers employer firms and does not include Schedule C self-employed activity, my analysis is limited to the formation of employer firms. As such, the commencement of Schedule C self-employed activity is unmeasured and is not considered to be entrepreneurship in this sample.

The LEHD database is a quarterly panel that identifies the employees of each firm in the U.S. and records worker compensation from the states' unemployment insurance benefit programs. It covers $95 \%$ of private sector employment and is generally comparable from state to state. ${ }^{1}$ The Census Bureau currently provides access to employment records from 25 states. $^{2}$ The data coverage starts in 1990 for several states and increases over time, ending in 2008. For each employee, the LEHD data provide age, gender, race, place of birth, and citizenship status. The database also links workers directly to the workers' employing entity in a given state, using State Employer Identification Numbers (SEIN), and provides worker quarterly earnings at the employing SEIN. The LEHD data include the federal employer identification number (EIN), which allows researchers to link the LEHD data to the firm identifiers in the LBD and to track employees dynamically from firm to firm. I match the LBD establishments to SEINs in the LEHD data as of the first quarter of each year using the internal Census bridge file. ${ }^{3}$ That match yields an annual panel of SEINs of the LBD firms in the first quarter of each year. With a slight abuse of notation, I call SEINs "establishments" throughout the dissertation.

For the sample of matched firms, I take a snapshot of all employees as of the first quarter of each year. This step creates an annual panel of the workforce potentially exposed to a distress shock

\footnotetext{
${ }^{1}$ Abowd, Stephens, Vilhuber, Andersson, McKinney, Roemer, and Woodcock (2009) provides a detailed description of the program and the data it generates. Stevens (2007) discusses LEHD coverage issues.

${ }^{2}$ The covered states are Arkansas, Georgia, Hawaii, Idaho, Illinois, Indiana, Iowa, Louisiana, Maine, Maryland, Montana, Nevada, New Jersey, New Mexico, North Carolina, North Dakota, Oklahoma, Oregon, Rhode Island, South Carolina, Tennessee, Utah, Vermont, Virginia, Washington, and Wisconsin.

${ }^{3}$ I merge establishments of the two Census sets as of the first quarter of each year because the LBD measures employment as of March 12 of each year.
} 
during that year. Using longitudinally consistent individual identifiers available in the LEHD data, I then track these employees over time. I take a second snapshot of these same workers exactly three years later, allowing for two full years to pass since the end of the year during which a distress event is defined. Figure 2.1 presents the timeline. The lag is motivated by the time necessary to start a firm and by the time it takes for a new firm to appear in the Census data. ${ }^{4}$ I identify the following groups: (1) employees who remain working for the original firm; (2) employees who are now employed at a different firm that I define as a start-up (i.e., a firm founded during or after the year during which the distress is defined; or, equivalently, a firm that is three years old or younger); (3) employees who are now employed at a different firm, which had existed prior to the year during which the distress is defined (i.e., a firm that is more than three years old); (4) employees who are now employed at a different firm of unknown age; and (5) employees who are no longer observed in the data. ${ }^{5}$ Employees may be dropped from the data because they either leave the work force or are now employed in an area outside the LEHD data coverage.

Equating entrepreneurship with new venture creation is now a standard practice in the business studies approach to entrepreneurship (Shane and Venkataraman (2000)). Anyone who joins a startup can be viewed as entrepreneurial due to the high risk associated with new ventures, but not all employees who move to start-ups are likely to be the start-up founders. The LEHD data do not designate the founders of a new firm. While earnings in the LEHD data include bonus pay and similar compensation, the data do not consistently record equity ownership of individuals. To proxy for company founders, I define an entrepreneur as an employee who moves to a start-up and is one of the top five earners at that start-up. ${ }^{6}$ Using these assumptions, I then calculate the future establishment-level entrepreneurship rate as the percent of an establishment's employees in year zero who become entrepreneurs in three years. I use this entrepreneurship variable as the main

\footnotetext{
${ }^{4}$ Parker (2009) reports that the median time period needed by an entrepreneur to plan and open a company is more than a year.

${ }^{5}$ If the employee works for several firms in the future, I select the employer with the highest earnings. The age of some firms is unknown, since not all firms in the LEHD data map to the LBD, which is used to determine firm age.

${ }^{6}$ Similarly, Kerr, Kerr, and Nanda (2014) defines entrepreneurship based on earnings rankings in the LEHD data.
} 
dependent variable in establishment-level analysis.

\section{Industry Distress and Financial Leverage Data}

Following Opler and Titman (1994), a three-digit SIC code industry is classified as distressed in a given year (base year) if from the beginning of that year the median two-year sales growth of public firms' segments in that industry is negative and the median two-year stock return is less than $-30 \%$. A fall in demand and an increase in input prices are typical drivers of industry distress, as reported by Gopalan and Xie (2011).

Using the Compustat Fundamental Annual Database to obtain firm sales information, CRSP to get stock returns, and the Compustat Business Segment Database to retrieve firm industry segment sales data, I select all single industry firm-years (firm-years with a single SIC-3 industry segment with positive sales in the Compustat Business Segment Database). The industry distress panel is generated by excluding observations (1) for which the reported industry segment sales differ from the consolidated firm sales by more than 5\% (to exclude firms that have sales in smaller, unreported segments); (2) with missing sales and stock return information; (3) with sales of less than \$20 million U.S. dollars; (4) in the financial sector (SIC codes 6000-6999); (5) in regulated industries (SIC codes 4900-4999); and (6) in industries with fewer than four firms.

I merge the industry distress panel with the establishment-level panel using establishment industry information, such that the workers are identified as of the first quarter of each industry distress year.

Since the Census data do not have information on firm leverage, I merge the establishment-level panel with Compustat using the internal Census Compustat/LBD crosswalk. This limits the sample of workers potentially exposed to financial distress to employees of public firms. However, these employees are tracked going forward to both public and private firms. The inclusion of private firms is necessary because majority of start-ups fall into this category. I discuss the consequences of this restriction in Section 3.4.

For firm financial leverage, I use book leverage measured as the ratio of long-term debt plus debt in current liabilities normalized by total firm assets (Opler and Titman (1994); Lemmon, 
Roberts, and Zender (2008)). I use book leverage because market values might forecast future growth opportunities. Firms that experience a loss of growth opportunities will experience a decline in equity values and a corresponding increase in their leverage ratios, as measured by market values. If the exit of workers during financial distress is related to the availability of forfeited investment opportunities, using market-based leverage will bias downwards the estimates of worker entrepreneurship due to financial distress.

\subsection{Empirical Methodology}

I identify a financially distressed firm as a firm with high ex ante financial leverage that is hit by a large, unexpected, negative, industry-wide shock. Such a firm must pay debt holders out of its sparse cash flows, reducing the resources available to fulfill implicit obligations, such as paying promised wage increases or investing in workers' ideas. A levered firm hit by a shock becomes a less attractive employer. Additionally, large shocks increase bankruptcy risk and job insecurity in firms with larger ex ante debt burdens. The strategy was first proposed by Opler and Titman (1994) and its variant was recently used by Giroud and Mueller (2015), who interacted ex ante leverage with a demand shock measured by changes in housing prices. Following Opler and Titman (1994), I define an industry as being in distress if the median sales growth of firms in that industry is negative (to identify cash flow shock) and the median stock return is less than $-30 \%$ (to ensure that the shock is unanticipated).

The identification strategy has several advantages. First, the definition of firm financial distress based on a shock unrelated to firm idiosyncratic performance helps reduce concerns that unobservable firm-level factors drive both worker entrepreneurship and firm financial leverage. For example, worker movement from bankrupt firms into start-ups might be driven by the lack of investment opportunities that leads firms to bankruptcy. Second, the shock is based on industry stock return, making it less likely that firms will have adjusted their leverage in anticipation. Third, a large shock is likely to affect the behavior of workers who face labor market frictions and hence are unlikely to break employment relationships after smaller shocks. Finally, firms are likely to be

sufficiently distant from their equilibrium leverage ratios, helping to identify the effect of financial 
distress on worker exit into start-ups (Hennessy and Strebulaev (2015)).

The strategy also has its limitations. Industry conditions can drive firms' demand for labor as well as workers' job opportunities and the incentives to found firms. I therefore include industryyear fixed effects to isolate the effect of firm financial leverage on workers who otherwise face the same industry conditions. Additionally, firms differentially exposed to industry shocks might choose a capital structure based on unobservable characteristics that correlate with worker entrepreneurship following industry shocks. The direction of the potential bias is ambiguous. If more risk-tolerant workers, who are more likely to start new businesses, sort into riskier, higher-leverage firms, then this sorting would bias upward the estimates of rates of worker entrepreneurship in distressed firms (Berk et al. (2010)). Conversely, the estimates might be biased downward if firms with high growth options, which are also likely to have more entrepreneurial workers, choose lower leverage levels (Myers and Majluf (1984); Gompers et al. (2005)). I add establishment fixed effects to control for time-invariant, unobservable heterogeneity.

Finally, regional factors may correlate with investments of existing firms, labor market conditions, and rates of entrepreneurship (Dougal, Parsons, and Titman (2015); Schmalz, Sraer, and Thesmar (2013)). This issue is addressed by including state-year fixed effects.

Following Opler and Titman (1994), I measure the firm financial leverage ratio two years prior to the base year, to ensure that there is no reverse causality from poor performance (due to industry distress) to high leverage.

To examine the effect of firm financial distress on the propensity of workers to start their own firms, I use a difference-in-difference approach. Specifically, I estimate at the establishment-level:

$$
\begin{aligned}
y_{\text {efist }+3} & =\beta_{I} \times \text { IndDistress }_{i t}+\beta_{L} \times \text { Leverage }_{f t-2} \\
& +\boldsymbol{\beta}_{\boldsymbol{F} \boldsymbol{D}} \times \text { Leverage }_{f t-2} \times \text { IndDistress }_{i t}+\alpha_{e}+\alpha_{i t}+\alpha_{\text {st }}+\gamma^{\prime} X_{\text {efist }}+\epsilon_{\text {efist }}
\end{aligned}
$$

where $e$ indexes establishment; $f$ indexes firm; $i$ indexes industry; $s$ indexes state; $t$ indexes time in years; $y$ is the dependent variable of interest (i.e., the percent of employees at an establishment $e$ of the firm $f$ in industry $i$ at time $t$ who become entrepreneurs at $t+3$ ); Leverage is the firm book 
financial leverage ratio lagged by two periods from the base year $t$; IndDistress is the industry distress indicator variable equal to one if industry $i$ is in distress in year $t ; \alpha_{e}, \alpha_{i t}$, and $\alpha_{s t}$ are establishment, industry-year, and state-year fixed effects, respectively; $X$ is a vector of control variables; and $\epsilon$ is the error term.

The main coefficient of interest identifying the effect of financial distress, $\beta_{F D}$, measures the effect of financial leverage on worker entrepreneurship following periods of industry distress relative to worker entrepreneurship after non-distress industry years, measured by $\beta_{L}$. Under the null hypothesis that industry downturns do not accelerate the exit of employees from relatively more levered firms into entrepreneurship, $\beta_{F D}$ should be equal to zero. Under the alternative hypothesis that industry shocks disproportionally affect more levered firms and propel employees into entrepreneurship, $\beta_{F D}$ is expected to be positive and measures how the increase in ex ante leverage impacts the percentage of employees who found start-ups after an industry distress year in excess of start-ups founded after non-distress industry years. For ease of exposition, I refer to relatively more levered firms with establishments in industry distress as being financially distressed.

Including establishment, industry-year, and state-year fixed effects controls for time-varying industry and local conditions as well as unobservable, time-invariant heterogeneity. Adding timevarying establishment and firm-level characteristics helps overcome some specific additional concerns. I include two establishment-level controls, measured as of the first quarter of the base year to reflect characteristics of workers in the establishment-worker panel: (1) establishment size (to control for the possibility that changes in establishment size drive employee entrepreneurship in financially distressed firms) and (2) establishment mean wage (to control for the possibility that more levered firms pay higher wages, relaxing capital constraints associated with opening a new business). The detailed description of variable construction is in Appendix B.

Economically weaker firms might become more levered and hence more vulnerable to the shock. For that reason, I also control for past profitability and investment opportunities. I add the following one year lagged firm-level variables: return on assets; sales growth; Tobin's Q; as well as investments and research and development expenses, both normalized by total firm assets. 
Some firm-level variables have been found to correlate with the propensity of employees to found new firms. Gompers et al. (2005) find that more employees leave young and focused firms to join start-ups. I include firm age and diversification status as control variables. I also control for firm size, asset tangibility, and firm cash holdings to account for potential changes in firm scale and asset characteristics that might correlate with changes in firm investment policy and leverage.

An important residual concern is that serial correlation of the error term can lead to understated standard errors, especially in difference-in-differences estimations (Bertrand, Duflo, and Mullainathan (2004)). In all regressions, I cluster standard errors at the SIC-3 industry level, to account for the presence of serial correlation within the same establishment and for any arbitrary correlation of the error terms across establishments in the same industry in any given year as well as over time.

To validate the strategy and determine that relatively more levered firms are more affected by industry distress, I estimate equation 2.1 with future establishment employment growth as the dependent variable. I provide regression estimates in Table A.1 in the Appendix. Consistent with prior literature, I find that establishments in financial distress have negative future employment growth. For example, using U.S. Census data, Giroud and Mueller (2015) find that establishments of relatively more financially levered firms have lower employment growth following demand shocks measured by changes in local housing prices.

\subsection{Summary Statistics}

The sample period extends from 1990 through 2003. (Census data are available from 1990 through 2008. I stop in 2003 to match the sample period with the worker- and startup-level analysis described in section 3.2). To be included in the sample, an establishment must (1) have positive employment, (2) have industry distress information, (3) have all establishment- and firm-level variables used in this study, and (4) be in the scope of the Economic Census. ${ }^{7}$ Since the identification

\footnotetext{
${ }^{7}$ Industries not in the scope include Agriculture, Forestry and Fishing (SIC Division A), Railroads (SIC 40), U.S. Postal Service (SIC 43), Elementary and Secondary Schools (SIC 821), Colleges and Universities (SIC 822), Labor Organizations (SIC 863), Political Organizations (SIC 865), Religious Organizations (SIC 866), Certificated Passenger Air Carriers (part of SIC 4512), and Public Administration (SIC Division J).
} 
strategy requires information on the industry affiliation of workers, I also exclude observations in which I cannot assign workers uniquely to a single industry. The final sample contains 91,100 establishment-years (rounded to the nearest hundred due to the Census Bureau's disclosure policies).

An average establishment comes from an industry segment within a firm that comprises $61 \%$ of the total firm employment $(61.3 / 61.1 \%$ in industry distress/non-distress years), reflecting the fact that the sample consists mainly of establishments from economically significant industries within the firm operations. In the sample, $3.1 \%$ of establishment-years are classified as being in industry distress - similar to Opler and Titman (1994), who identify $3 \%$ of observations to be in industry distress. The small percent of observations in industry distress reflects the severity of the shock.

To gauge the representativeness of observations exposed to industry shocks, Table 2.1 provides summary statistics of ex ante establishment and firm characteristics. Column [1] presents results using all available establishment-years. Column [2] ([3]) limits observations to non-distress (distress) industry-years. For each variable, columns [1] - [3] report the mean (standard deviation), which is calculated at the establishment-year level. ${ }^{8}$ Column [4] provides differences in means for observations during industry distress vs. non-distress years. By ex ante establishment characteristics, observations in industry distress do not differ significantly from those in non-distress years. However, establishment-years in industry distress belong to older firms with lower financial leverage, fewer tangible assets, and more cash. By measures of total capital, profitability, and investment opportunities, establishment-years look similar across the two industry conditions.

Table 2.2 provides summary statistics of future worker entrepreneurship calculated at the establishment level. According to the main definition of entrepreneurship used in this dissertation (variable "Pct Entrepreneurs"), an average of $1.5 \%$ of public firm employees will leave and become entrepreneurs in a subsequent three-year period, measured from the first quarter of the base year (the year during which distress is defined) to the first quarter three years later. Similarly, 1.4 new start-ups per 100 workers are created over the three-year period (variable "Pct Startups"). The

\footnotetext{
${ }^{8}$ Due to the Census Bureaus disclosure policy, I cannot report median or other percentile values.
} 
discrepancy between the two variables is likely due to some start-ups being founded by former co-workers. Although the figures seem small, they are consistent with the previous estimates of employer firm creation rates. Business Dynamics Statistics, created from the LBD by the U.S. Census Department, identified about 11 new employer establishments per 100,000 individuals per quarter in 2012, or $1.32 \%$ over three years. Similarly, using the LBD/LEHD matched data Kerr et al. (2014) find that $1.7 \%$ of workers transition to entrepreneurship over a four-year period. ${ }^{9}$ On average, among employees who switch employers, only $4 \%$ will become entrepreneurs (variable "Pct Entrepreneurs/Change Employer"). When I consider only the top earner in a start-up as an entrepreneur, the mean future entrepreneurship rate falls to $0.5 \%$ (variable "Pct Main Founder"), highlighting rare worker-to-top-founder transitions.

To get a sense of correlation between industry shocks and post-shock worker entrepreneurship, Table 2.2 also provides statistics on worker entrepreneurship by industry distress indicator. In the univariate analysis, the rates of entrepreneurship become slightly higher after industry distress years, but the difference is not consistently significant. I next turn to multivariate analysis to determine if industry shocks disproportionally affect the ability of relatively more levered firms to retain entrepreneurial employees.

\footnotetext{
${ }^{9}$ The annual transitions into self-employment are substantially higher. The Kauffman Foundation estimates that $0.3 \%$ of people open up a new business (employer or non-employer) per month in 2012 (Fairlie (2013), pp. 4 and 6).
} 


\section{Figure 2.1: Timeline}

This graph shows when the main variables are measured. Following Opler and Titman (1994), I identify an industry to be in distress in a base year, $t=0$, if from the beginning of that year the median two-year sales growth of firms in that industry is negative and the median two-year stock return is less than $-30 \%$. I measure firm book financial leverage ratio (long-term debt plus debt in current liabilities, normalized by total firm assets) two years prior to the base year, at $t=-2$. Firms' workers are identified as of the first quarter of the base year, at $t=0$. Allowing for two full years to pass since the end of the base year during which the distress is defined, I determine where those workers are in the first quarter of $t=+3$ : stay with the firm, leave to work for another firm that existed prior to $t=0$, drop out from the employment sample, or leave to work for a startup (a firm founded from $t=0$ to $t=+3$, inclusively). In the first quarter of $t=+3$, a former worker is an entrepreneur if he works at a startup and is one of the top five earners at that start-up.

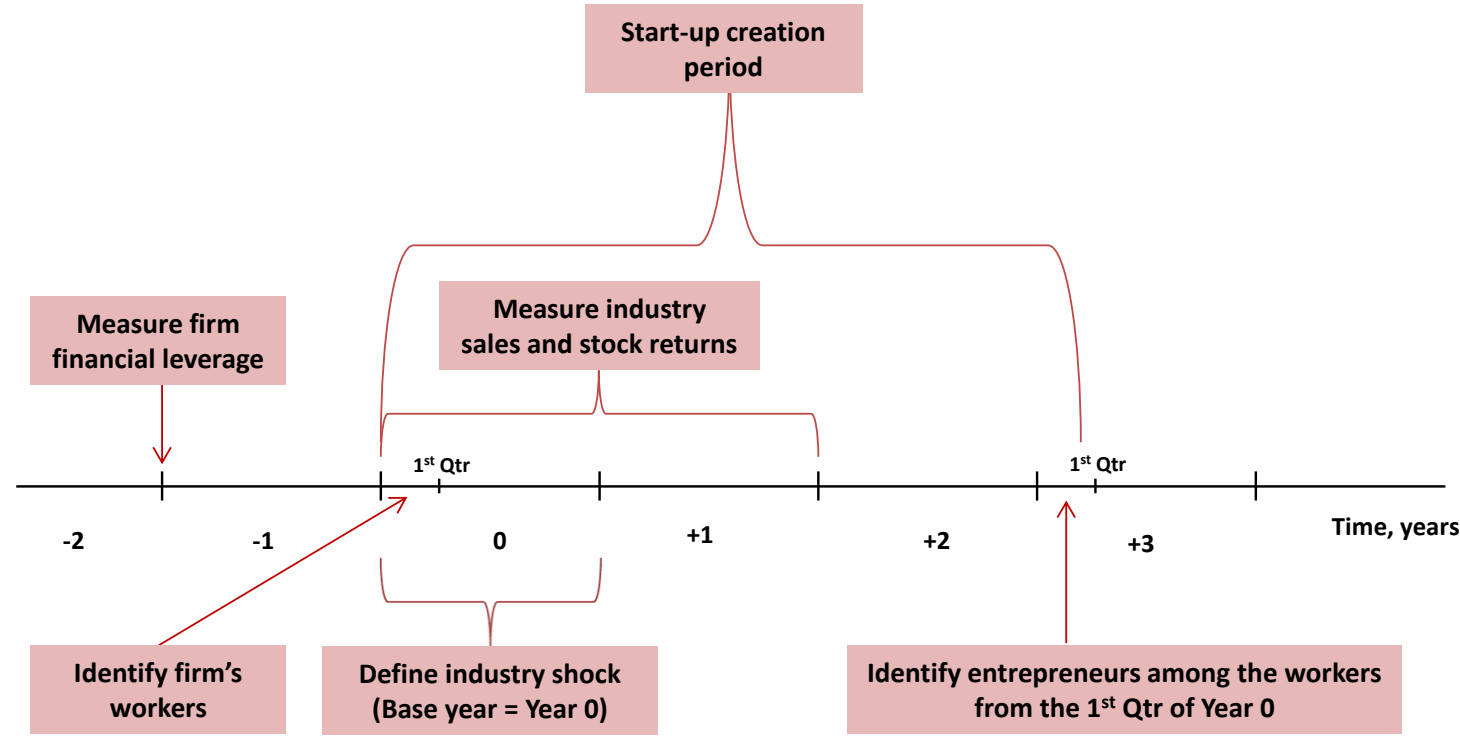




\section{Table 2.1: Summary Statistics: Ex Ante Establishment and Parent Firm Characteristics}

This table presents establishment-level summary statistics. The sample consists of establishments of U.S. public firms, and extends from 1990 through 2003. "All" refers to all observations in the sample. "Not Industry Distress" refers to observations not in industry distress years. "Industry Distress" refers to observations in industry distress years. $3.1 \%$ of establishment-years are classified as being in industry distress years. In columns [1] - [3], sample means (standard deviations) are computed across all establishment-year observations. Column [4] provides differences in means. All establishment-level variables are measured as of the first quarter of the base year (the year during which distress is defined). Establishment Size is the natural logarithm of establishment employment. Establishment Mean Wage is the natural logarithm of the ratio of an establishment's payroll to employment. Leverage is the firm book financial leverage ratio (long-term debt plus debt in current liabilities, normalized by total firm assets) lagged by two years from the base year. Firm Age is equal to the age of the oldest establishment that a firm owns. Diversified Firm is an indicator variable equal to one if a firm owns establishments in more than one SIC-3 industry. The remaining firm variables are lagged by one year from the base year. Detailed variable definitions are in the Appendix A. Standard errors are clustered at the SIC-3 industry code. ${ }^{*},{ }^{* *}$, and ${ }^{* * *}$ denote significance at the $10 \%, 5 \%$, and $1 \%$ levels.

\begin{tabular}{|c|c|c|c|c|}
\hline & $\begin{array}{l}\text { All } \\
{[1]}\end{array}$ & $\begin{array}{c}\text { Not Industry } \\
\text { Distress } \\
{[2]}\end{array}$ & $\begin{array}{c}\text { Industry } \\
\text { Distress } \\
{[3]}\end{array}$ & $\begin{array}{c}\text { Difference } \\
([3]-[2]) \\
{[4]}\end{array}$ \\
\hline \multicolumn{5}{|l|}{ Ex Ante Establishment Characteristics } \\
\hline Establishment Size & $\begin{array}{c}4.208 \\
(1.762)\end{array}$ & $\begin{array}{c}4.199 \\
(1.757)\end{array}$ & $\begin{array}{c}4.458 \\
(1.920)\end{array}$ & 0.258 \\
\hline Establishment Mean Wage & $\begin{array}{c}9.090 \\
(0.857)\end{array}$ & $\begin{array}{c}9.082 \\
(0.853)\end{array}$ & $\begin{array}{c}9.339 \\
(0.933)\end{array}$ & 0.257 \\
\hline Establishment Mean Worker Age & $\begin{array}{l}37.187 \\
(6.805)\end{array}$ & $\begin{array}{l}37.150 \\
(6.829)\end{array}$ & $\begin{array}{l}38.338 \\
(5.921)\end{array}$ & 1.188 \\
\hline Establishment Percent Female & $\begin{array}{c}0.440 \\
(0.275)\end{array}$ & $\begin{array}{c}0.442 \\
(0.276)\end{array}$ & $\begin{array}{c}0.383 \\
(0.248)\end{array}$ & -0.059 \\
\hline Establishment Mean Worker Education & $\begin{array}{l}13.610 \\
(1.079)\end{array}$ & $\begin{array}{l}13.604 \\
(1.077)\end{array}$ & $\begin{array}{l}13.824 \\
(1.106)\end{array}$ & 0.220 \\
\hline Establishment Mean Worker Tenure & $\begin{array}{c}1.984 \\
(1.596)\end{array}$ & $\begin{array}{c}1.983 \\
(1.595)\end{array}$ & $\begin{array}{c}2.021 \\
(1.638)\end{array}$ & 0.038 \\
\hline \multicolumn{5}{|l|}{ Ex Ante Firm Characteristics } \\
\hline Leverage & $\begin{array}{c}0.255 \\
(0.204)\end{array}$ & $\begin{array}{c}0.257 \\
(0.205)\end{array}$ & $\begin{array}{c}0.213 \\
(0.175)\end{array}$ & $-0.043^{* *}$ \\
\hline Firm Age & $\begin{array}{l}21.285 \\
(5.262)\end{array}$ & $\begin{array}{l}21.237 \\
(5.252)\end{array}$ & $\begin{array}{l}22.777 \\
(5.360)\end{array}$ & $1.541^{* * *}$ \\
\hline Diversified Firm & $\begin{array}{c}0.941 \\
(0.236)\end{array}$ & $\begin{array}{c}0.942 \\
(0.234)\end{array}$ & $\begin{array}{c}0.920 \\
(0.271)\end{array}$ & -0.022 \\
\hline Firm Sales Growth & $\begin{array}{c}0.163 \\
(0.315)\end{array}$ & $\begin{array}{c}0.162 \\
(0.313)\end{array}$ & $\begin{array}{c}0.185 \\
(0.364)\end{array}$ & 0.023 \\
\hline Firm Return on Assets & $\begin{array}{c}0.172 \\
(0.114)\end{array}$ & $\begin{array}{c}0.173 \\
(0.113)\end{array}$ & $\begin{array}{c}0.155 \\
(0.121)\end{array}$ & -0.018 \\
\hline Firm Investments & $\begin{array}{c}0.077 \\
(0.074)\end{array}$ & $\begin{array}{c}0.077 \\
(0.074)\end{array}$ & $\begin{array}{c}0.064 \\
(0.062)\end{array}$ & -0.013 \\
\hline Firm R\&D & $\begin{array}{c}0.016 \\
(0.041)\end{array}$ & $\begin{array}{c}0.016 \\
(0.041)\end{array}$ & $\begin{array}{c}0.027 \\
(0.056)\end{array}$ & 0.012 \\
\hline Firm Tobin's Q & $\begin{array}{c}0.464 \\
(0.483)\end{array}$ & $\begin{array}{c}0.464 \\
(0.481)\end{array}$ & $\begin{array}{c}0.468 \\
(0.550)\end{array}$ & 0.004 \\
\hline Firm Size & $\begin{array}{c}6.831 \\
(1.870)\end{array}$ & $\begin{array}{c}6.827 \\
(1.866)\end{array}$ & $\begin{array}{c}6.960 \\
(1.987)\end{array}$ & 0.133 \\
\hline Firm Asset Tangibility & $\begin{array}{c}0.313 \\
(0.208)\end{array}$ & $\begin{array}{c}0.317 \\
(0.208)\end{array}$ & $\begin{array}{c}0.196 \\
(0.158)\end{array}$ & $-0.121^{* * *}$ \\
\hline Firm Cash & $\begin{array}{c}0.086 \\
(0.113)\end{array}$ & $\begin{array}{c}0.085 \\
(0.112)\end{array}$ & $\begin{array}{c}0.114 \\
(0.150)\end{array}$ & $0.029^{* *}$ \\
\hline Number of Observations & 91,100 & 88,276 & 2,824 & \\
\hline
\end{tabular}




\section{Table 2.2: Summary Statistics: Ex Post Worker Entrepreneurship}

This table presents establishment-level summary statistics. The sample consists of establishments of U.S. public firms, and extends from 1990 through 2003. "All" refers to all observations in the sample. "Not Industry Distress" refers to observations not in industry distress years. "Industry Distress" refers to observations in industry distress years. $3.1 \%$ of establishment-years are classified as being in industry distress years. In columns [1] - [3], sample means (standard deviations) are computed across all establishment-year observations. Column [4] provides differences in means. Pct Entrepreneurs is the count of an establishment's workers defined as future entrepreneurs two years after the base year (the year during which distress is defined), normalized by base year establishment employment and expressed in percentage terms; a worker is a future entrepreneur if, two years after the base year, he works at a start-up (a firm founded during or after the base year) and is also one of the top five earners at that start-up (main definition). Pct Entrepreneurs/Change Employer is the count of an establishment's workers who are defined as future entrepreneurs according to the main definition, normalized by the number of the establishment's employees who work for a different employer two years after the base year and expressed in percentage terms. Pct Main Founder is the count of an establishment's workers who, two years after the base year, work at start-ups and are also the top earners at those start-ups, normalized by base year establishment employment and expressed in percentage terms. Pct Startups is the count of unique start-ups associated with future entrepreneurs defined according to the main definition, normalized by base year establishment employment and expressed in percentage terms. Detailed variable definitions are in the Appendix A. Standard errors are clustered at the SIC-3 industry code. ${ }^{*},{ }^{* *}$, and *** denote significance at the $10 \%$, $5 \%$, and $1 \%$ levels.

\begin{tabular}{|c|c|c|c|c|}
\hline & All & $\begin{array}{l}\text { Not Industry } \\
\text { Distress }\end{array}$ & $\begin{array}{l}\text { Industry } \\
\text { Distress }\end{array}$ & $\begin{array}{c}\text { Difference } \\
([3]-[2])\end{array}$ \\
\hline & [1] & [2] & & \\
\hline Pct Entrepreneurs & $\begin{array}{c}1.509 \\
(3.937)\end{array}$ & $\begin{array}{c}1.504 \\
(3.944)\end{array}$ & $\begin{array}{c}1.643 \\
(3.700)\end{array}$ & 0.139 \\
\hline Pct Entrepreneurs/Change Employer & $\begin{array}{c}4.070 \\
(9.003)\end{array}$ & $\begin{array}{c}4.069 \\
(9.007)\end{array}$ & $\begin{array}{c}4.127 \\
(8.885)\end{array}$ & 0.058 \\
\hline Pct Main Founder & $\begin{array}{c}0.520 \\
(2.351)\end{array}$ & $\begin{array}{c}0.518 \\
(2.362)\end{array}$ & $\begin{array}{c}0.605 \\
(1.994)\end{array}$ & $0.087^{*}$ \\
\hline Pct Startups & $\begin{array}{c}1.385 \\
(0.915)\end{array}$ & $\begin{array}{c}1.382 \\
(0.913)\end{array}$ & $\begin{array}{c}1.467 \\
(0.979)\end{array}$ & 0.085 \\
\hline Number of Observations & 91,100 & 88,276 & 2,824 & \\
\hline
\end{tabular}




\section{CHAPTER 3: EMPIRICAL EVIDENCE}

\subsection{The Effect of Financial Distress on the Quantity of Worker Entrepreneurship}

In this section, I use the difference-in-difference approach, described in section 2.2 , to study the effects of financial distress on the rate of worker entrepreneurship.

\section{The Effect of Financial Distress on the Rate of Worker Entrepreneurship}

Table 3.1 shows the effect of firm financial leverage on future employee entrepreneurship after non-distressed and after distressed industry-years. Columns [1] - [3] show the effect of financial distress on the rate of future employee entrepreneurship after controlling for time-varying industry conditions by including industry-year fixed effects. In these regressions, high leverage is defined relative to other firms in the same industry and year. After non-distress industry years, financial leverage has a positive but economically small effect on employee entrepreneurship. The effect of financial leverage on the future entrepreneurship rate increases five-fold after industry distress years. A one standard deviation increase in ex ante leverage increases the rate of departures to entrepreneurship after industry distress years by a quarter of a percentage point, or a $17 \%$ increase from the average establishment-level entrepreneurship rate of $1.5 \%$.

Columns [2] and [3] include controls for other time-varying factors. In column [2], the inclusion of the state-year fixed effects does not change the estimates of the interaction coefficient, reducing the likelihood that local shocks drive worker entrepreneurship in financially distressed firms. In column [3], I account for the possibility that time-varying establishment or firm characteristics drive the results. Establishment-level controls are establishment size and average wage. ${ }^{1}$ Firm-level controls are firm age, diversification, and the following financial variables lagged by

\footnotetext{
${ }^{1}$ The inclusion of worker characteristics that might be correlated with the propensity to take risk (age and gender) or with the experience required to open up a business (education and total labor market experience) averaged at the establishment-year level did not change the magnitude or the significance of the main coefficients.
} 
one year from the base year: sales growth, return on assets, investments, R\&D expenses, Tobin's Q, firm size, asset tangibility, and cash holdings. The estimates of the main coefficient do not change, suggesting that time-varying establishment or firm characteristics are less likely to be the main drivers of the results. ${ }^{2}$

Little is known about how public firm characteristics correlate with the rate of worker transitions into young employer firms. I therefore highlight some interesting correlations in Column [3]. Within an industry-year, relatively larger establishments experience lower rates of worker entrepreneurship. This result might suggest that workers in smaller establishments likely have more diverse responsibilities, and thus acquire the broader skill sets that are helpful in entrepreneurship (Lazear (2009)). Similar to findings in Gompers et al. (2005), who study venture-backed start-ups, fewer workers exit older and diversified firms to join employer start-ups, VC-backed or not. Establishments of firms with past sales growth and investments above industry average experience higher rates of entrepreneurship. Spawning does not depend significantly on aboveindustry-average R\&D expenses, Tobin's Q, or cash holdings, but is more pronounced in firms with fewer tangible assets. Consistent with Elfenbein et al. (2010), I find a negative correlation between firm size and exit rates of workers into start-ups.

Columns [4] - [6] of Table 3.1 present the results estimated with an establishment fixed effects model, which controls for time-invariant heterogeneity across establishments. ${ }^{3}$ In these regressions, high leverage in an establishment in a given year is defined relative to average leverage

\footnotetext{
${ }^{2}$ Table 3.1 shows that controlling for past profitability does not change the main results, suggesting that firms with weak performance prior to distress do not drive worker entrepreneurship. I perform additional tests to address the concern that economically, and not financially distressed firms, drive employee entrepreneurship in distressed firms. Following Andrade and Kaplan (1998), I identify firms with negative operating income prior to industry distress as more likely to be economically weak. I find that the results are not driven by firms with poor performance prior to industry distress. See Table A.2 in the Appendix for the regression analysis.

${ }^{3}$ Since each establishment can be located in only one state and very few establishments change industry definition, the inclusion of establishment fixed effects controls for time-invariant state of location and industry characteristics. I use establishment fixed effects as opposed to firm fixed effects to control for potential differences in the number of establishments within a firm across financial distress and non-distress years. The results with firm fixed effects are similar and are presented in Table A.3 in the Online Appendix.
} 
within-establishment. Column [4] only includes establishment fixed effects. It shows that relatively high leverage has no effect on worker entrepreneurship after non-distress industry years. However, it does increase entrepreneurship after industry distress years. The estimate of the interaction term increases to $2 \%$ from $1.2 \%$ estimated with industry-year fixed effects, potentially suggesting that firms more exposed to industry shocks might choose lower leverage levels and that industry-year fixed effects might not fully control for that unobserved heterogeneity. Columns [5] and [6] control for the possibility that time-variant omitted variables drive changes in leverage and worker entrepreneurship. The inclusion of these controls has little effect on the estimate of the financial distress coefficient. Using within-establishment variation, firm characteristics found important for rates of entrepreneurship in Column [3] are now insignificant, but the coefficient on firm R\&D expenses becomes positive and significant. Given very limited variability in firm-level R\&D expenses, this result needs to be interpreted with caution.

In Columns [7] - [9] of Table 3.1, I add industry-year fixed effects to establishment fixed effects to address the concern that industry factors drive changes in leverage. In these regressions, the within-establishment changes in leverage are adjusted for industry-year means. The estimate of the financial distress coefficient is little changed by adding industry-year fixed effects, remains statistically significant, and is also similar after the inclusion of state-year fixed effects and the other time-varying variables considered earlier.

I next look at the pre-shock trend in entrepreneurship in financially distressed firms. In this setting, the difference-in-difference identification strategy requires that relatively more levered firms do not experience a higher exit rate of workers into entrepreneurship prior to the shock. Table 3.1 shows that, on average, within a given establishment, relatively higher leverage is not positively related to the exit of workers into start-ups after non-distress industry years. However, a run-up in entrepreneurship might still occur just prior to the industry shock. If that were the case, then some yet uncontrolled-for time-variant variable might be driving changes in leverage and worker exit into start-ups. I verify that relatively more levered firms do not experience a higher exit rate of workers into entrepreneurship during the period leading up to industry distress. This result 
suggests that no pre-trend exists of worker exit into start-ups.

The results presented in this section show that financial distress increases the quantity of entrepreneurs. To show the results graphically, I predict and plot in Figure 3.1 the percentage of establishment workers who become entrepreneurs after distress vs. non-distress industry years as a function of leverage estimated from the establishment fixed effects model. The figure highlights that relatively high leverage has a minimal effect on worker entrepreneurship after non-distress industry years. However, after industry downturns, relatively higher-leverage firms experience a higher exodus of workers into entrepreneurship.

\section{Alternative Measures of Worker Entrepreneurship}

In this section I summarize several supplemental analyses that test the robustness of the results to using alternative measures of worker entrepreneurship. I start by exploring whether the results are sensitive to using a more restrictive definition of entrepreneurship. The main variable defines any of the top five earners in a start-up as founders, likely mis-classifying some of the first employees as founders. To proxy for the main founder of the start-up, I re-define only the top earner in a start-up as the founder. As with the main variable definition, I normalize the number of future entrepreneurs by pre-distress establishment employment. In Table 3.2, columns [1] - [4] show that the "main founder" definition produces similar results in terms of statistical and economic significance, suggesting that the pattern holds for the most important start-up founder.

I also verify that financial distress is followed by an increase in the number of start-ups. If financial distress encourages co-worker team starts, then the total number of start-ups might not increase even though the total number of workers moving to start-ups increases. Redefining the dependent variable as the number of unique start-ups associated with the start-up founders leaving public firms, normalized by pre-distress employment, yields similar results (Table 3.2, columns [5] - [8]).

The main definition measures entrepreneurship at a point in time, taking a snapshot of entrepreneurs three years after the start of distress. This definition will miss any employee moving to 
a start-up but quitting before the snapshot is taken. Survivorship bias would occur if distress creates higher-quality entrepreneurs who are more likely to persist in entrepreneurship. Redefining an entrepreneur as someone who founds a start-up within either one, two, or three years following distress yields results similar to those obtained using the main definition.

The analysis presented in this section extends the main results by showing that financial distress spurs new firm creation and increases the supply of firm founders. Since the increase might be due to higher worker turnover in financially weaker firms, I next analyze the role of overall turnover in generating the results.

\section{The Role of Worker Turnover in the Increased Rate of Entrepreneurship}

The main definition normalizes the number of future entrepreneurs by the pre-distress period employment to capture the effect of financial distress on the propensity of ex ante employees to become entrepreneurs. However, if more workers separate from financially distressed firms, then more workers are likely to become entrepreneurs. With the aim of controlling for turnover directly, I define two additional variables to determine whether more workers who leave their firms are more likely to become entrepreneurs. First, I normalize the number of future entrepreneurs by the number of workers employed by a different firm in the post-distress period, and present the results in Table 3.3. Second, I normalize the number of future entrepreneurs by the number of workers who, after three years, work for a different firm or who drop out of the employment sample, and present the results for this definition in Table A.4 in the Appendix. ${ }^{4}$ Both alternative definitions produce very similar estimates in terms of sign and significance, suggesting that financial distress affects the transition rates of workers specifically to entrepreneurship.

Next, I examine if worker turnover is indeed higher in financially distressed firms. The evidence on lower employment growth in financially weak firms presented in section 2.2 is consistent with prior findings (Chodorow-Reich (2014); Giroud and Mueller (2015)); however, existing literature does not differentiate worker departures from declines in new hires when presenting changes in

\footnotetext{
${ }^{4}$ For both definitions, I set the value of the establishment's future entrepreneurship equal to zero to avoid dropping the observation in cases where the value is undefined because no workers leave an establishment. The results are similar in terms of statistical and economic significance if I drop observations with no worker departures.
} 
employment growth. Negative growth may well be driven by cuts in new hires. To measure the effect of firm distress on worker turnover, I calculate the percent of workers at each establishment who stay to work at their current firm for three years (equivalently, for two years following the end of a potentially distressed year). In the sample, an average of $36 \%$ of public firm workers stay with their employer over a subsequent three-year period, measured from the first quarter of the base year (the year during which distress is defined). The estimate is consistent with high turnover estimates in papers that use the LEHD data (Bjelland, Fallick, Haltiwanger, and McEntarfer (2011); Graham et al. (2015)). Table 3.4, columns [1] - [2], shows that indeed, fewer workers stay with more financially levered employers following industry shocks.

The departures from distressed firms can be driven by the documented increase in entrepreneurial separations. Alternatively, workers moving to other established firms or becoming unemployed might also contribute to the overall increase in turnover. I analyze the different departures in which the separating workers move to work for firms that existed prior to the shock (variable "Pct Move Existing"), drop out from the labor sample ("Pct Drop-out"), or move to start-ups ("Pct Move Startups"). Over the same three-year period, $32 \%$ of workers leave to work for firms that existed prior to the base year, $17 \%$ of workers drop out from the LEHD employment sample, $3.8 \%$ move to work for start-ups (firms founded since the base year). ${ }^{5}$ I estimate equation 2.1 with these turnover variables as the dependent variables and present the results in Table 3.4. The findings do not show that employees at more levered public firms are significantly more likely to move to other established firms or drop out from the employment sample following industry shocks. Conversely, workers are more likely to move to start-ups.

One way to interpret these findings is that, due to firm-specific investments or other labor market frictions, workers with no aspirations for entrepreneurship stay with the financially weak employer to wait out the storm, while entrepreneurial workers leave because the opportunity cost

\footnotetext{
${ }^{5}$ The remaining $11 \%$ of workers leave to work for other firms with unknown age. The LBD is used to determine firm age. Since not all firms in the LEHD data map to the LBD, the age of some firms is unknown.
} 
of postponing the development of an entrepreneurial idea is high. ${ }^{6}$ Another possibility is that workers who found start-ups are poor performers who are fired by the financially distressed firm. I cannot observe whether the start-up founders were laid-off, so I turn to examining the quality of entrepreneurs and the firms they found.

${ }^{6}$ Results presented in this dissertation do not imply that general worker separations would not increase in more severed cases of financial distress, such as bankruptcy. 
Figure 3.1: Predicted Entrepreneurship as a Function of Firm Financial Leverage After Distress vs. Non-Distress Industry Years

This graph shows predicted future worker entrepreneurship as a function of firm financial leverage after distress and non-distress industry years. The predicted values are plotted along with the corresponding confidence intervals. The predicted values and their confidence intervals are estimated from the following equation:

$$
y_{\text {efit }+3}=\beta_{L} \times \text { Leverage }_{f t-2}+\beta_{I} \times \text { IndDistress }_{i t}+\boldsymbol{\beta}_{\boldsymbol{F} \boldsymbol{D}} \times \text { Leverage }_{f-2} \times \text { IndDistress }_{i t}+\alpha_{e}+\epsilon_{e f i t}
$$

where $e$ indexes establishments, $f$ indexes firm, $i$ indexes industry, $t$ indexes time in years; $y$ is the percent of employees at the establishment $e$ of the firm $f$ in industry $i$ at time $t$ who become entrepreneurs at $t+3$; Leverage is the firm book financial leverage ratio (long-term debt plus debt in current liabilities, normalized by total firm assets) measured at $t-2$; IndDistress is an indicator variable equal to one if the industry-year $i t$ is in distress; $\alpha_{e}$ is establishment fixed effects; and $\epsilon$ is the error term. The vertical bar "Mean Leverage" is an average firm leverage across all establishment-years.

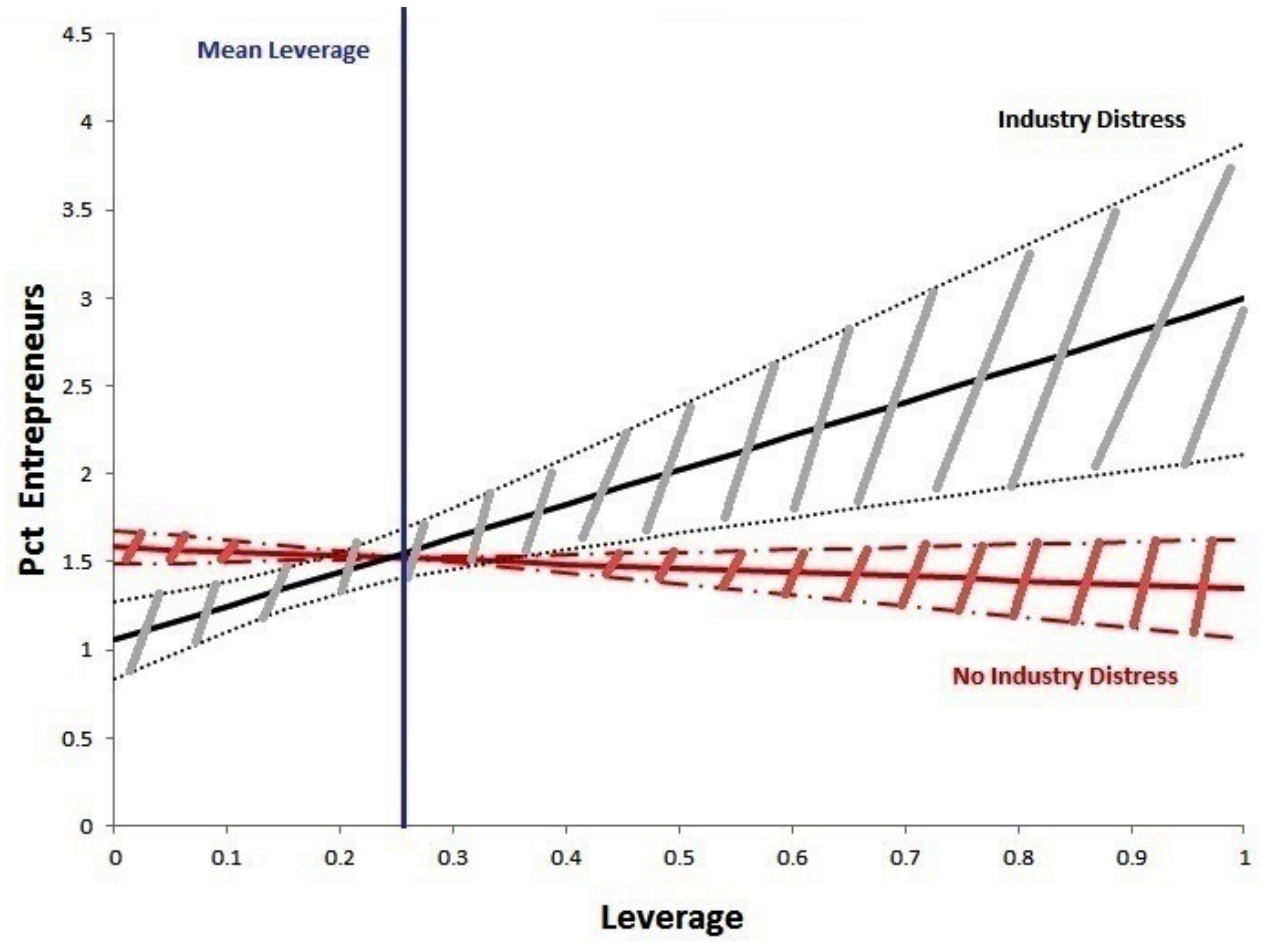




\section{Table 3.1: The Effect of Firm Financial Distress on the Rate of Worker Entrepreneurship}

This table presents establishment-level analysis. The sample consists of establishments of U.S. public firms, and extends from 1990 through 2003. The dependent variable Pct Entrepreneurs is the count of an establishment's workers defined as future entrepreneurs two years after the base year (the year during which distress is defined), normalized by base year establishment employment and expressed in percentage terms; a worker is a future entrepreneur if, two years after the base year, he works at a start-up (a firm founded during or after the base year) and is also one of the top five earners at that start-up. IndDistress is an indicator variable equal to one if an industry-year is in distress. Leverage is the firm book financial leverage ratio (long-term debt plus debt in current liabilities, normalized by total firm assets) lagged by two years from the base year. Detailed variable definitions are in the Appendix A. Note: since the industry distress indicator is collinear with the industry-year fixed effects, the coefficient on IndDistress cannot be estimated in columns [1] - [3] and is imprecisely estimated with few observations in columns [7] - [9] and hence is not reported. Standard errors are clustered at the SIC-3 code industry-level and are in parentheses. ${ }^{*},{ }^{* *}$, and ${ }^{* * *}$ denote significance at the $10 \%, 5 \%$, and $1 \%$ levels.

\begin{tabular}{|c|c|c|c|c|c|c|c|c|c|}
\hline \multirow[t]{2}{*}{ Dependent Variable: } & \multicolumn{9}{|c|}{ Pct Entrepreneurs } \\
\hline & [1] & {$[2]$} & [3] & [4] & {$[5]$} & {$[6]$} & [7] & {$[8]$} & [9] \\
\hline IndDistress & & & & $\begin{array}{c}-0.456 * * * \\
(0.113)\end{array}$ & $\begin{array}{c}-0.463 * * * \\
(0.123)\end{array}$ & $\begin{array}{c}-0.467 * * * \\
(0.111)\end{array}$ & & & \\
\hline Leverage & $\begin{array}{c}0.336^{* *} \\
(0.154)\end{array}$ & $\begin{array}{c}0.336 * * \\
(0.153)\end{array}$ & $\begin{array}{c}0.308 * * \\
(0.146)\end{array}$ & $\begin{array}{l}-0.235 \\
(0.191)\end{array}$ & $\begin{array}{l}-0.179 \\
(0.192)\end{array}$ & $\begin{array}{l}-0.122 \\
(0.196)\end{array}$ & $\begin{array}{l}-0.219 \\
(0.200)\end{array}$ & $\begin{array}{l}-0.195 \\
(0.196)\end{array}$ & $\begin{array}{l}-0.153 \\
(0.204)\end{array}$ \\
\hline Leverage $\times$ IndDistress & $\begin{array}{l}1.167 * * \\
(0.459)\end{array}$ & $\begin{array}{c}1.186 * * * \\
(0.442)\end{array}$ & $\begin{array}{l}1.275^{* *} \\
(0.611)\end{array}$ & $\begin{array}{c}1.939 * * * \\
(0.541)\end{array}$ & $\begin{array}{c}1.952 * * * \\
(0.558)\end{array}$ & $\begin{array}{c}1.957 * * * \\
(0.536)\end{array}$ & $\begin{array}{c}1.846^{* * * *} \\
(0.571)\end{array}$ & $\begin{array}{c}1.851 * * * \\
(0.595)\end{array}$ & $\begin{array}{c}1.857 * * * \\
(0.588)\end{array}$ \\
\hline Establishment Size & & & $\begin{array}{l}-0.144 * * * \\
(0.021)\end{array}$ & & & $\begin{array}{c}0.059 \\
(0.060)\end{array}$ & & & $\begin{array}{c}0.068 \\
(0.065)\end{array}$ \\
\hline Establishment Mean Wage & & & $\begin{array}{l}-0.061 \\
(0.053)\end{array}$ & & & $\begin{array}{c}0.099 \\
(0.094)\end{array}$ & & & $\begin{array}{c}0.113 \\
(0.100)\end{array}$ \\
\hline Firm Age & & & $\begin{array}{c}-0.019 * * * \\
(0.005)\end{array}$ & & & $\begin{array}{l}-0.007 \\
(0.011)\end{array}$ & & & $\begin{array}{l}-0.013 \\
(0.014)\end{array}$ \\
\hline Diversified Firm & & & $\begin{array}{l}-0.179 * * * \\
(0.066)\end{array}$ & & & $\begin{array}{c}0.015 \\
(0.125)\end{array}$ & & & $\begin{array}{c}0.015 \\
(0.121)\end{array}$ \\
\hline Firm Sales Growth & & & $\begin{array}{l}0.220 * * * \\
(0.067)\end{array}$ & & & $\begin{array}{l}-0.006 \\
(0.068)\end{array}$ & & & $\begin{array}{l}-0.042 \\
(0.074)\end{array}$ \\
\hline Firm Return on Assets & & & $\begin{array}{c}-0.841 * * \\
(0.330)\end{array}$ & & & $\begin{array}{l}-0.104 \\
(0.279)\end{array}$ & & & $\begin{array}{l}-0.161 \\
(0.330)\end{array}$ \\
\hline Firm Investments & & & $\begin{array}{c}0.990 * * \\
(0.413)\end{array}$ & & & $\begin{array}{c}0.244 \\
(0.271)\end{array}$ & & & $\begin{array}{c}0.269 \\
(0.235)\end{array}$ \\
\hline Firm R\&D & & & $\begin{array}{l}-0.177 \\
(0.941)\end{array}$ & & & $\begin{array}{l}2.784 * \\
(1.480)\end{array}$ & & & $\begin{array}{l}2.753^{*} \\
(1.526)\end{array}$ \\
\hline Firm Tobin's Q & & & $\begin{array}{l}-0.018 \\
(0.062)\end{array}$ & & & $\begin{array}{l}0.100^{*} \\
(0.060)\end{array}$ & & & $\begin{array}{c}0.063 \\
(0.072)\end{array}$ \\
\hline Firm Size & & & $\begin{array}{c}-0.062 * * * \\
(0.015)\end{array}$ & & & $\begin{array}{c}0.008 \\
(0.044)\end{array}$ & & & $\begin{array}{c}0.023 \\
(0.055)\end{array}$ \\
\hline Firm Asset Tangibility & & & $\begin{array}{c}-0.416^{* * *} \\
(0.152)\end{array}$ & & & $\begin{array}{l}-0.093 \\
(0.368)\end{array}$ & & & $\begin{array}{l}-0.159 \\
(0.391)\end{array}$ \\
\hline Firm Cash & & & $\begin{array}{c}0.001 \\
(0.267)\end{array}$ & & & $\begin{array}{l}-0.193 \\
(0.292)\end{array}$ & & & $\begin{array}{l}-0.103 \\
(0.303)\end{array}$ \\
\hline Industry-Year FE & Yes & Yes & Yes & & & & Yes & Yes & Yes \\
\hline State-Year FE & & Yes & Yes & & Yes & Yes & & Yes & Yes \\
\hline Establishment FE & & & & Yes & Yes & Yes & Yes & Yes & Yes \\
\hline R-squared & 0.024 & 0.028 & 0.035 & 0.510 & 0.512 & 0.512 & 0.519 & 0.520 & 0.520 \\
\hline Number of Observations & 91,100 & 91,100 & 91,100 & 91,100 & 91,100 & 91,100 & 91,100 & 91,100 & 91,101 \\
\hline
\end{tabular}




\section{Table 3.2: The Effect of Firm Financial Distress on the Rate of Worker Entrepreneurship: Alterna- tive Definitions of Worker Entrepreneurship}

This table presents establishment-level analysis. The sample consists of establishments of U.S. public firms, and extends from 1990 through 2003. The table reports results with alternative definitions of entrepreneurship. Pct Main Founder is the count of an establishment's workers who, two years after the base year (the year during which distress is defined), work at start-ups (a firm founded during or after the base year) and are also the top earners at those startups, normalized by base year establishment employment and expressed in percentage terms. Pct Startups is the count of unique start-ups associated with future entrepreneurs defined according to the main definition, normalized by base year establishment employment and expressed in percentage terms; a worker is a future entrepreneur if, two years after the base year, he works at a start-up and is also one of the top five earners at that start-up. IndDistress is an indicator variable equal to one if an industry-year is in distress. Leverage is the firm book financial leverage ratio (long-term debt plus debt in current liabilities, normalized by total firm assets) lagged by two years from the base year. Establishment controls include establishment size and average worker wage. Firm controls are firm age, diversification, and the following financial variables lagged by one year: sales growth, return on assets, investments, R\&D expenses, Tobin's $\mathrm{Q}$, firm size, asset tangibility, and cash holdings. Detailed variable definitions are in the Appendix A. Standard errors are clustered at the SIC-3 code industry-level and are in parentheses. ${ }^{*},{ }^{* *}$, and ${ }^{* * *}$ denote significance at the $10 \%$, $5 \%$, and $1 \%$ levels.

\begin{tabular}{|c|c|c|c|c|c|c|c|c|}
\hline \multirow[t]{2}{*}{ Dependent Variable: } & \multicolumn{4}{|c|}{ Pct Main Founder } & \multicolumn{4}{|c|}{ Pct Startups } \\
\hline & {$[1]$} & {$[2]$} & {$[3]$} & {$[4]$} & {$[5]$} & {$[6]$} & [7] & [8] \\
\hline IndDistress & $\begin{array}{c}-0.227 * * * \\
(0.073)\end{array}$ & $\begin{array}{c}-0.233^{* * *} * \\
(0.070)\end{array}$ & & & $\begin{array}{c}-0.360 * * * \\
(0.091)\end{array}$ & $\begin{array}{c}-0.363^{* * *} * \\
(0.085)\end{array}$ & & \\
\hline Leverage & $\begin{array}{l}-0.039 \\
(0.095)\end{array}$ & $\begin{array}{l}-0.022 \\
(0.100)\end{array}$ & $\begin{array}{l}-0.057 \\
(0.102)\end{array}$ & $\begin{array}{c}-0.051 \\
(0.109)\end{array}$ & $\begin{array}{l}-0.126 \\
(0.156)\end{array}$ & $\begin{array}{l}-0.082 \\
(0.162)\end{array}$ & $\begin{array}{c}-0.126 \\
(0.158)\end{array}$ & $\begin{array}{c}-0.098 \\
(0.166)\end{array}$ \\
\hline Leverage $\times$ IndDistress & $\begin{array}{c}0.965 * * * \\
(0.281)\end{array}$ & $\begin{array}{c}0.972 * * * \\
(0.273)\end{array}$ & $\begin{array}{c}1.056^{* * * *} \\
(0.321)\end{array}$ & $\begin{array}{c}1.057 * * * \\
(0.319)\end{array}$ & $\begin{array}{c}1.379 * * * \\
(0.357)\end{array}$ & $\begin{array}{c}1.382 * * * \\
(0.356)\end{array}$ & $\begin{array}{c}1.190 * * * \\
(0.330)\end{array}$ & $\begin{array}{c}1.196 * * * \\
(0.326)\end{array}$ \\
\hline Industry-Year FE & & & Yes & Yes & & & Yes & Yes \\
\hline State-Year FE & Yes & Yes & Yes & Yes & Yes & Yes & Yes & Yes \\
\hline Establishment FE & Yes & Yes & Yes & Yes & Yes & Yes & Yes & Yes \\
\hline Establishment Controls & & Yes & & Yes & & Yes & & Yes \\
\hline Firm Controls & & Yes & & Yes & & Yes & & Yes \\
\hline R-squared & 0.492 & 0.493 & 0.502 & 0.502 & 0.470 & 0.470 & 0.478 & 0.478 \\
\hline Number of Observations & 91,100 & 91,100 & 91,100 & 91,100 & 91,100 & 91,100 & 91,100 & 91,100 \\
\hline
\end{tabular}


Table 3.3: The Effect of Firm Financial Distress on the Rate of Entrepreneurship Among Departing Workers

This table presents establishment-level analysis. The sample consists of establishments of U.S. public firms, and extends from 1990 through 2003. The table reports the results with alternative normalization of future entrepreneurs. The dependent variable Pct Entrepreneurs/Change Employer is the count of an establishment's workers defined as future entrepreneurs two years after the base year (the year during which distress is defined), normalized by the number of the establishment's employees who work for a different employer two years after the base year, and expressed in percentage terms; a worker is a future entrepreneur if, two years after the base year, he works at a start-up (a firm founded during or after the base year) and is also one of the top five earners at that start-up. IndDistress is an indicator variable equal to one if an industry-year is in distress. Leverage is the firm book financial leverage ratio (long-term debt plus debt in current liabilities, normalized by total firm assets) lagged by two years from the base year. Establishment controls include establishment size and average worker wage. Firm controls are firm age, diversification, and the following financial variables lagged by one year: sales growth, return on assets, investments, R\&D expenses, Tobin's Q, firm size, asset tangibility, and cash holdings. Detailed variable definitions are in the Appendix A. Standard errors are clustered at the SIC -3 code industry-level and are in parentheses. ${ }^{*},{ }^{* *}$, and ${ }^{* * *}$ denote significance at the $10 \%$, $5 \%$, and $1 \%$ levels.

\begin{tabular}{lcccccc}
\hline Dependent Variable: & \multicolumn{7}{c}{ Pct Entrepreneurs/Change Employer } \\
& {$[1]$} & {$[2]$} & {$[3]$} & {$[4]$} & {$[5]$} & {$[6]$} \\
\hline IndDistress & & & $-1.312^{* *}$ & $-1.308^{* * *}$ & & \\
& & & $(0.509)$ & $(0.456)$ & & \\
Leverage & 0.256 & 0.375 & -0.540 & -0.391 & -0.545 & -0.450 \\
& $(0.309)$ & $(0.266)$ & $(0.471)$ & $(0.491)$ & $(0.488)$ & $(0.516)$ \\
Leverage $\times$ IndDistress & $3.508^{* * *}$ & $3.885^{* * *}$ & $4.567^{* *}$ & $4.541^{* *}$ & $4.644^{* *}$ & $4.651^{* *}$ \\
& $(1.026)$ & $(1.396)$ & $(2.089)$ & $(1.983)$ & $(2.210)$ & $(2.154)$ \\
Industry-Year FE & Yes & Yes & & & Yes & Yes \\
State-Year FE & Yes & Yes & Yes & Yes & Yes & Yes \\
Establishment FE & & & Yes & Yes & Yes & Yes \\
Establishment Controls & \multicolumn{7}{c}{ Yes } & & Yes & & Yes \\
Firm Controls & 0.027 & 0.030 & 0.455 & 0.455 & 0.465 & 0.466 \\
R-squared & 91,100 & 91,100 & 91,100 & 91,100 & 91,100 & 91,100 \\
Number of Observations & & & & & & \\
\hline
\end{tabular}




\section{Table 3.4: Worker Turnover in Financially Distressed Firms}

This table presents establishment-level analysis. Pct Stay is the percent of an establishment's workers who, two years after the base year (the year during which distress is defined), still work at the firm. Pct Move Existing is the percent of an establishment's workers who, two years after the base year, work at a different firm that existed prior to the base year. Pct Drop-out is the percent of an establishment's workers who, two years after the base year, are not observed in the employment sample. Pct Move Startups is the percent of the establishment's workers who, two years after the base year, work at start-ups (a firm founded during or after the base year). IndDistress is an indicator variable equal to one if an industry-year is in distress. Leverage is the firm book financial leverage ratio (long-term debt plus debt in current liabilities, normalized by total firm assets) lagged by two years from the base year. Establishment controls include establishment size and average worker wage. Firm controls are firm age, diversification, and the following financial variables lagged by one year: sales growth, return on assets, investments, R\&D expenses, Tobin's Q, firm size, asset tangibility, and cash holdings. Detailed variable definitions are in the Appendix A. The sample consists of establishments of U.S. public firms, and extends from 1990 through 2003. Standard errors are clustered at the SIC-3 code industry-level and are in parentheses. ${ }^{*},{ }^{* *}$, and ${ }^{* * *}$ denote significance at the $10 \%, 5 \%$, and $1 \%$ levels.

\begin{tabular}{|c|c|c|c|c|c|c|c|c|}
\hline \multirow[t]{2}{*}{ Dependent Variable: } & \multicolumn{2}{|c|}{ Pct Stay } & \multicolumn{2}{|c|}{ Pct Move Existing } & \multicolumn{2}{|c|}{ Pct Drop-out } & \multicolumn{2}{|c|}{ Pct Move Startups } \\
\hline & {$[1]$} & [2] & {$[3]$} & {$[4]$} & {$[5]$} & {$[6]$} & [7] & {$[8]$} \\
\hline Leverage & $\begin{array}{c}0.549 \\
(1.180)\end{array}$ & $\begin{array}{c}0.342 \\
(1.208)\end{array}$ & $\begin{array}{c}0.911 \\
(1.063)\end{array}$ & $\begin{array}{c}1.047 \\
(1.108)\end{array}$ & $\begin{array}{l}-0.598 \\
(0.484)\end{array}$ & $\begin{array}{l}-0.571 \\
(0.502)\end{array}$ & $\begin{array}{c}-0.371 \\
(0.381)\end{array}$ & $\begin{array}{l}-0.231 \\
(0.372)\end{array}$ \\
\hline Leverage $\times$ IndDistress & $\begin{array}{l}-7.541^{*} \\
(4.276)\end{array}$ & $\begin{array}{l}-7.516^{*} \\
(4.302)\end{array}$ & $\begin{array}{c}4.586 \\
(3.699)\end{array}$ & $\begin{array}{c}4.524 \\
(3.538)\end{array}$ & $\begin{array}{c}0.264 \\
(1.612)\end{array}$ & $\begin{array}{c}0.264 \\
(1.662)\end{array}$ & $\begin{array}{c}2.458^{* * * *} \\
(0.816)\end{array}$ & $\begin{array}{c}2.450 * * * \\
(0.792)\end{array}$ \\
\hline Industry-Year FE & Yes & Yes & Yes & Yes & Yes & Yes & Yes & Yes \\
\hline State-Year FE & Yes & Yes & Yes & Yes & Yes & Yes & Yes & Yes \\
\hline Establishment FE & Yes & Yes & Yes & Yes & Yes & Yes & Yes & Yes \\
\hline Establishment Controls & & Yes & & Yes & & Yes & & Yes \\
\hline Firm Controls & & Yes & & Yes & & Yes & & Yes \\
\hline R-squared & 0.794 & 0.795 & 0.737 & 0.739 & 0.609 & 0.610 & 0.577 & 0.577 \\
\hline Number of Observations & 91,100 & 91,100 & 91,100 & 91,100 & 91,100 & 91,100 & 91,100 & 91,100 \\
\hline
\end{tabular}




\subsection{The Effect of Financial Distress on the Quality of Entrepreneurship}

In the previous section, I documented that firm financial distress increases the quantity of entrepreneurs. In this section, I explore whether that increase is driven by high- or low-quality workers. Layoffs are more common among lower-quality workers (Gibbons and Katz (1991)), while start-ups of laid-off workers are less likely to create jobs or survive (Parker (2009); Pfeiffer and Reize (2000)). Thus, we might observe a decline in the average quality of entrepreneurs and the firms they found, if the increase is driven by laid-off workers. Understanding the type of entrepreneurs spurred by financial distress helps to shed light on economic mechanisms responsible for the results and assess implications of the increase in entrepreneurship triggered by financial distress.

\section{The Effect of Firm Financial Distress on the Quality of Entrepreneurs}

The LEHD database contains worker earnings histories at each firm and thereby provides an opportunity to gauge the quality of entrepreneurs created by financial distress. Existing literature has documented that, prior to exiting paid employment, workers who become entrepreneurs earn more than other workers (Hamilton (2000); Giannetti and Simonov (2009)). Controlling for industry, location, worker, establishment, and firm characteristics, I confirm that, prior to exiting paid employment, the average earnings for entrepreneurs in my sample exceed those of other workers within a given establishment. Thus, using earning as a proxy for worker quality, entrepreneurs appear to be higher quality than their co-workers.

To assess the quality of entrepreneurs created after financial distress relative to other workers within an establishment, I separately count future entrepreneurs within sub-samples of employees in the top and bottom halves of an establishment's wage distributions and repeat the main analysis from Table 3.1. I present the results for the top (bottom) half of wage distribution in Table 3.5, Panel A (Panel B). Table 3.5 shows that the sensitivity of entrepreneurship rate to financial distress is more pronounced among the top half of wage earners, suggesting that entrepreneurship spawned by financial distress is not driven by lower-quality workers within a firm.

I next focus on the sample of entrepreneurs and analyze whether the quality of entrepreneurs 
depends on the degree of financial distress of spawning firms. I retrieve wages earned prior to exiting paid employment to proxy for worker quality and wages earned after joining start-ups to proxy for quality in entrepreneurship. I define ex ante earnings as the natural logarithm of the real wages earned at a public firm during the quarter the worker is identified with that firm. I define ex post earnings as the natural logarithm of total, three-year, real wages earned from the time an employee is identified as a start-up founder. ${ }^{7}$ I also measure future worker wage growth as the log-difference between ex post and ex ante wages. ${ }^{8}$

Summary statistics on entrepreneur wages and other personal characteristics are in Table 3.6. Table 3.6 shows that workers founding start-ups following industry distress years do not differ significantly by proxies of risk aversion (such as gender and age), by tenure at a public firm, or by earnings. I next turn to multivariate analysis to determine if earnings of workers exiting after industry shocks are correlated with the leverage of spawning firms.

As a relatively rare event, entrepreneurship provides limited variation for within-establishment difference-in-difference comparisons. I use an industry-year fixed effects regression specification, with the caveat that the results should be interpreted as comparing entrepreneurs from more- vs. less-levered firms within a given industry-year cell.

In particular, I estimate the following model at the entrepreneur level:

$$
\begin{aligned}
y_{\text {wefist }} & =\beta_{L} \times \text { Leverage }_{f t-2}+\boldsymbol{\beta}_{\boldsymbol{F} \boldsymbol{D}} \times \text { Leverage }_{f t-2} \times \text { IndDistress }_{i t} \\
& +\alpha_{i t}+\alpha_{i s}+\gamma^{\prime} X_{\text {wefist }}+\epsilon_{\text {wefist }}
\end{aligned}
$$

where $w$ indexes workers and all other indices are as defined in equation 2.1,y is the dependent

\footnotetext{
${ }^{7}$ For example, for the employee identified at a public firm in the first quarter of 1998 who left and was identified as a start-up founder in the first quarter of 2001, I take a natural logarithm of the total real earnings over 2001, 2002, and 2003. I do not restrict earnings to those derived from the start-up because that would require the start-up's conditional survival for at least three years. Studying the performance of survivors may yield interesting data, but a more general question concerns the future performance of all entrepreneurs.

${ }^{8}$ To measure worker wage growth, I calculate the ex ante wages in a manner similar to that of the ex post wages for consistency. For example, for an employee working for a public firm in the first quarter of 1998, I calculate ex ante wages as a natural logarithm of the total real earnings over 1995, 1996 and 1997.
} 
variable of interest (ex ante or ex post real earnings of worker $w$ identified at establishment $e$ in industry $i$ of firm $f$ in state $s$ and at time $t$ ), and $\alpha_{i t}$ and $\alpha_{i s}$ are industry-year and state-year fixed effects, respectively. $X$ is a vector of firm and establishment control variables included in the main analysis, as well as worker-level control variables. Since the industry distress indicator is collinear with the industry-year fixed effects, the coefficient on IndDistress cannot be estimated in this specification.

Columns [1] and [2] of Table 3.8 present the results on ex ante earnings. Column [1] includes worker-level controls. Column [2] adds establishment- and firm-level controls. ${ }^{9}$ Financial leverage is not correlated with earnings of workers who found start-ups following non-distress industry years. However, among workers who become entrepreneurs following industry downturns, entrepreneurs who exit from more financially levered firms earn higher wages prior to exit than those who leave less levered firms. When all controls are included, a one standard deviation in leverage is associated with $10 \%$ higher earnings.

Columns [3] - [4] ([5] - [6]) present the results on ex post earnings (earnings growth). Column [3] ([5]) includes worker-level controls; column [4] ([6]) adds establishment- and firm-level controls. Similar to the results on ex ante earnings, financial leverage is not correlated with either earnings or earnings growth of workers who found start-ups following non-distress industry years. Both future earnings and earnings growth are positively associated with ex ante firm leverage for workers transitioning into entrepreneurship after industry distress years.

The earnings results suggest that workers who transition into entrepreneurship due to financial distress are not necessarily bad workers. On the contrary, the entrepreneurs from financially distressed firms are on average better, making it less likely that mechanisms by which low-quality workers found new employer firms explain the main results.

\section{The Effect of Firm Financial Distress on the Quality of Startups}

If, indeed, financial distress propels better workers into entrepreneurship, then the performance

\footnotetext{
${ }^{9}$ Worker-level controls include worker age, age squared, female indicator, race indicator (equal to one if white), worker education (years of education, which is imputed in the LEHD data), foreign born indicator, born in state indicator, total experience (number of years in the LEHD data), and tenure (number of years at the establishment).
} 
of their start-ups likely depends on the degree of financial distress as well. I test whether future start-up employment growth depends on the financial distress of the spawning firm. I also examine start-up survival as another dimension of start-up performance.

I start by selecting all start-ups associated with the employee-entrepreneurs studied in the previous section. I use the LBD to estimate long-term survival and growth and define an indicator variable as equal to one if the start-up exits within five years. I retrieve start-ups' employment five years after it is identified with the entrepreneur. In the case where a start-up exits, I set natural logarithm of future employment to zero. I measure future employment growth as the log-differences between the future and initial employments. To gauge a start-up's business relatedness to the spawning establishment, I create an indicator variable equal to one when an SIC-2 industry of the start-up and the spawning establishment is the same.

Table 3.7 contains summary statistics. On average, start-ups are 1.6 years old when they are identified with the worker previously employed by a public firm. Only $17 \%$ of all start-ups are in the same industry as the spawning establishment. Startups spawned after industry distress are more likely to be in a different industry from the spawning establishment's industry, compared to startups spawned after non-distress periods. However, this result is not significant in a univariate analysis. On average, start-ups founded following industry distress years have slightly lower employment in the first year of their operation, but they are not more likely to exit within five years. Consistent with prior literature, about $50 \%$ of start-ups survive for five years (Robb and Reedy (2012)). However, univariate analysis shows that start-ups founded following industry distress years have 5.6\% lower future employment growth. I next test in a multivariate setting how survival and growth of start-ups founded following industry distress years are associated the financial leverage of the spawning firms.

As with the entrepreneur-level analysis, I estimate an industry-year fixed effects regression specification at the start-up - entrepreneur pair level. Columns [1] and [2] of Table 3.9 present analysis of start-up survival as a function of financial distress estimated with a linear probability 
model. ${ }^{10}$

Column [1] presents coefficients estimated while controlling for worker and start-up characteristics. Column [2] also adds firm- and establishment-level control variables. Startup exit is negatively correlated with financial distress, as the interaction term between ex ante financial leverage and industry distress is negative, but the result becomes insignificant when all controls are included.

Future start-up employment (in columns [3] - [4]) and employment growth (in columns [5] [6]) are both significantly positively correlated with the degree of financial distress of the spawning public firms. The interaction between ex ante financial leverage and industry distress remains stable when I include firm, establishment, worker, and startup-level control variables. A one standard deviation increase in ex ante leverage is associated with 3.4\% higher five-year employment growth of start-ups founded by workers after an industry shock.

Since little is generally known about how characteristics of spawning firms correlate with the performance of start-ups, I highlight some interesting correlations from Table 3.9. Startups founded by higher-wage workers experience a lower exit rate and a higher future growth rate. Also intuitive is that workers who come from high $\mathrm{R} \& \mathrm{D}$ firms found riskier start-ups with a higher exit rate. What is less expected is that start-ups of workers from financially distressed firms grow faster, but are not riskier as measured by exit rate. This finding runs counter to the expectation that high-growth start-ups should also exhibit high risk profiles, such as the ones founded by the employees from high R\&D firms. Also notable: when a founder's ex ante wages are included as a control variable, the estimates of the start-up growth rate do not fall, suggesting that the start-ups founded by workers from financially distressed firms have some other edge over other start-ups besides founder ability. I will analyze potential mechanisms underlying the results in section 4 .

\footnotetext{
${ }^{10}$ I use linear probability model because my coefficient of interest is an interaction, which cannot be interpreted as marginal effects in logit or probit models due to non-linearity. I verify that the sign and significance of the interaction coefficient between financial leverage and industry distress is similar if estimated with the logit model.
} 
Table 3.5: The Effect of Firm Financial Distress on the Rate of Entrepreneurship Within the Top Half and the Bottom Half of Wage Earners

This table presents establishment-level analysis. The sample consists of establishments of U.S. public firms, and extends from 1990 through 2003. Panel A (Panel B) presents the results using workers within the top (bottom) half of the earnings distribution within an establishment-year. In both panels, the dependent variable is Pct Entrepreneurs, which is calculated within each respective earnings group. Pct Entrepreneurs is the count of an establishment's workers defined as future entrepreneurs two years after the base year (the year during which distress is defined), normalized by base year establishment employment and expressed in percentage terms; a worker is a future entrepreneur if, two years after the base year, he works at a start-up (a firm founded during or after the base year) and is also one of the top five earners at that start-up. IndDistress is an indicator variable equal to one if an industry-year is in distress. Leverage is the firm book financial leverage ratio (long-term debt plus debt in current liabilities, normalized by total firm assets) lagged by two years from the base year. Establishment controls include establishment size and average worker wage. Firm controls are firm age, diversification, and the following financial variables lagged by one year: sales growth, return on assets, investments, $R \& D$ expenses, Tobin's $Q$, firm size, asset tangibility, and cash holdings. Detailed variable definitions are in the Appendix A. Standard errors are clustered at the SIC- 3 code industry-level and are in parentheses. ${ }^{*},{ }^{* *}$, and ${ }^{* * *}$ denote significance at the $10 \%, 5 \%$, and $1 \%$ levels.

Panel A: Workers in the Top Half of an Establishment Wage Distribution

\begin{tabular}{lcccccc}
\hline \multirow{2}{*}{ Dependent Variable: } & \multicolumn{7}{c}{ Pct Entrepreneurs } \\
& {$[1]$} & {$[2]$} & {$[3]$} & {$[4]$} & {$[5]$} & {$[6]$} \\
\hline IndDistress & & & $-0.456^{* *}$ & $-0.469^{* *}$ & & \\
& & & $(0.205)$ & $(0.185)$ & & \\
Leverage & $0.455^{* *}$ & $0.408^{* *}$ & -0.110 & -0.011 & -0.134 & -0.045 \\
& $(0.176)$ & $(0.167)$ & $(0.258)$ & $(0.259)$ & $(0.266)$ & $(0.271)$ \\
Leverage $\times$ IndDistress & $1.576^{* * *}$ & $1.685^{* * *}$ & $2.313^{* *}$ & $2.318^{* *}$ & $2.117^{* *}$ & $2.107^{* *}$ \\
& $(0.495)$ & $(0.642)$ & $(0.924)$ & $(0.892)$ & $(0.856)$ & $(0.831)$ \\
Industry-Year FE & Yes & Yes & & & Yes & Yes \\
State-Year FE & Yes & Yes & Yes & Yes & Yes & Yes \\
Establishment FE & & & Yes & Yes & Yes & Yes \\
Establishment Controls & & Yes & & Yes & & Yes \\
Firm Controls & & Yes & & Yes & & Yes \\
R-squared & 0.028 & 0.034 & 0.527 & 0.527 & 0.536 & 0.536 \\
Number of Observations & 91,100 & 91,100 & 91,100 & 91,100 & 91,100 & 91,100 \\
\hline
\end{tabular}

Panel B: Workers in the Bottom Half of an Establishment Wage Distribution

\begin{tabular}{lcccccc}
\hline Dependent Variable: & \multicolumn{7}{c}{ Pct Entrepreneurs } & & \\
& {$[1]$} & {$[2]$} & {$[3]$} & {$[4]$} & {$[5]$} & {$[6]$} \\
\hline IndDistress & & & $-0.459^{* * *}$ & $-0.452^{* * *}$ & & \\
& & & $(0.125)$ & $(0.123)$ & & \\
Leverage & 0.230 & 0.227 & -0.294 & -0.282 & -0.316 & -0.319 \\
& $(0.156)$ & $(0.150)$ & $(0.212)$ & $(0.221)$ & $(0.233)$ & $(0.243)$ \\
Leverage $\times$ IndDistress & 0.843 & 0.908 & $1.680^{* * *}$ & $1.682^{* * *}$ & $1.638^{* *}$ & $1.658^{* *}$ \\
& $(0.661)$ & $(0.807)$ & $(0.563)$ & $(0.553)$ & $(0.712)$ & $(0.719)$ \\
Industry-Year FE & Yes & Yes & & & Yes & Yes \\
State-Year FE & Yes & Yes & Yes & Yes & Yes & Yes \\
Establishment FE & & & Yes & Yes & Yes & Yes \\
Establishment Controls & & Yes & & Yes & & Yes \\
Firm Controls & & Yes & & Yes & & Yes \\
R-squared & 0.021 & 0.024 & 0.428 & 0.428 & 0.435 & 0.436 \\
Number of Observations & 91,100 & 91,100 & 91,100 & 91,100 & 91,100 & 91,100 \\
\hline
\end{tabular}




\section{Table 3.6: Summary Statistics: Workers Who Become Entrepreneurs}

This table presents statistics on worker-level variables. The sample consists of workers who found new firms after exiting establishments of U.S. public firms from 1990 through 2003. "All" refers to all observations in the sample. "Not Industry Distress" refers to workers who found new firms after leaving public firms in non-distressed industryyears. "Industry Distress" refers to workers who found new firms after leaving public firms in distressed industry-years. In columns [1] - [3], sample means (standard deviations) are computed across all observations. Column [4] provides differences in means. Worker Age is measured in years. Worker Female is an indicator variable equal to one if female. Worker Education is the number of years of a worker education. Worker Tenure is the number of years a worker is at the establishment of a public firm. Worker Ex Ante Earnings is the natural logarithm of real wages earned at a public firm during the quarter the worker is identified with that firm. Worker Ex Post Earnings is the natural logarithm of total three-year real wages earned since the worker became identified as an entrepreneur. Worker Earnings Growth is the log-difference between ex post and ex ante earnings. Detailed variable definitions are in the Appendix A. Standard errors are clustered at the SIC-3 industry code. ${ }^{*},{ }^{* *}$, and ${ }^{* * *}$ denote significance at the $10 \%, 5 \%$, and $1 \%$ levels.

\begin{tabular}{lcccc}
\hline & All & $\begin{array}{c}\text { Not Industry } \\
\text { Distress } \\
{[2]}\end{array}$ & $\begin{array}{c}\text { Industry } \\
\text { Distress } \\
{[3]}\end{array}$ & $\begin{array}{c}\text { Difference } \\
{[[3]-[2])} \\
{[4]}\end{array}$ \\
\hline Worker Age & 32.195 & 32.116 & 33.585 & 1.468 \\
Worker Female & $(11.180)$ & $(11.181)$ & $(11.073)$ & \\
& 0.462 & 0.464 & 0.424 & -0.039 \\
Worker Education & $(0.499)$ & $(0.499)$ & $(0.494)$ & \\
Worker Tenure & 13.221 & 13.218 & 13.268 & 0.050 \\
Worker Ex Ante Earnings & $(2.430)$ & $(2.430)$ & $(2.432)$ & \\
& 1.495 & 1.508 & 1.264 & -0.244 \\
Worker Ex Post Earnings & $(1.766)$ & $(1.773)$ & $(1.637)$ & \\
& $(1.606)$ & $(1.591)$ & $(1.836)$ & \\
Worker Earnings Growth & 9.881 & 9.887 & 9.790 & -0.096 \\
& $(1.141)$ & $(1.138)$ & $(1.189)$ & \\
Number of Observations & $(1.047$ & 0.053 & -0.058 & -0.111 \\
& 315,200 & $(1.281)$ & $(1.289)$ & \\
\hline
\end{tabular}




\section{Table 3.7: Summary Statistics: Startups Founded by Former Workers}

This table presents statistics on start-up variables. The sample consists of start-ups founded by workers who exit establishments of U.S. public firms from 1990 through 2003. "All" refers to all observations in the sample. "Not Industry Distress" refers to new firms founded by workers leaving public firms not in industry distress years. "Industry Distress" refers to new firms founded by workers leaving public firms in industry distress years In columns [1] - [3], sample means (standard deviations) are computed across all observations. Column [4] provides differences in means. Startup Age at Joining is the start-up age in years during the year it is identified with the entrepreneur, taking values from one to three, inclusively. Startup Same Ind is an indicator variable equal to one if an SIC-2 industry of the startup and the spawning establishment is the same. Startup Initial Empl is the natural logarithm of start-up employment plus one in the first year of the start-up's existence. Startup Exit is an indicator variable equal to one if a start-up exits by the fifth year since it became identified with the entrepreneur. Startup Future Empl is the natural logarithm of start-up employment plus one in five years since it became identified with the entrepreneur. Startup Empl Growth is the log-difference between start-up future and initial employments. Detailed variable definitions are in the Appendix A. Standard errors are clustered at the SIC-3 industry code. ${ }^{*},{ }^{* *}$, and ${ }^{* * *}$ denote significance at the $10 \%, 5 \%$, and $1 \%$ levels.

\begin{tabular}{lcccc}
\hline & All & $\begin{array}{c}\text { Not Industry } \\
\text { Distress } \\
{[2]}\end{array}$ & $\begin{array}{c}\text { Industry } \\
\text { Distress } \\
{[3]}\end{array}$ & $\begin{array}{c}\text { Difference } \\
([3]-[2]) \\
{[4]}\end{array}$ \\
\hline Startup Age at Joining & 1.609 & 1.611 & 1.569 & $-0.042^{* * *}$ \\
& $(1.008)$ & $(1.007)$ & $(1.020)$ & \\
Startup Same Ind & 0.171 & 0.173 & 0.131 & -0.042 \\
& $(0.376)$ & $(0.378)$ & $(0.337)$ & \\
Startup Initial Empl & 0.185 & 0.186 & 0.169 & $-0.017^{* *}$ \\
& $(0.618)$ & $(0.620)$ & $(0.566)$ & \\
Startup Exit & 0.482 & 0.482 & 0.487 & 0.005 \\
Startup Future Empl & $(0.500)$ & $(0.500)$ & $(0.500)$ & \\
& 1.078 & 1.082 & 1.014 & $-0.068^{* * *}$ \\
Startup Empl Growth & $(1.306)$ & $(1.309)$ & $(1.255)$ & \\
& 0.987 & 0.990 & 0.933 & $-0.056^{* * *}$ \\
Number of Observations & $(1.267)$ & $(1.269)$ & $(1.225)$ & \\
\hline
\end{tabular}




\section{Table 3.8: The Effect of Firm Financial Distress on the Quality of Entrepreneurs}

This table presents entrepreneur-level analysis. The sample consists of workers who found new firms after exiting establishments of U.S. public firms from 1990 through 2003. Worker Ex Ante Earnings is the natural logarithm of real wages earned at a public firm during the quarter the worker is identified with that firm. Worker Ex Post Earnings is the natural logarithm of total three-year real wages earned since the worker became identified as an entrepreneur. Worker Earnings Growth is the log-difference between ex post and ex ante earnings. Worker-level control variables include worker age, worker age squared, female indicator, white indicator, worker foreign born indicator, worker in-state born indicator, worker education, worker total experience, and worker tenure. Table A.7 in the Appendix provides estimates of the coefficients on worker control variables. Detailed variable definitions are in the Appendix A. Standard errors are clustered at the SIC-3 code industry-level and are in parentheses. ${ }^{*},{ }^{* *}$, and ${ }^{* * *}$ denote significance at the $10 \%$, $5 \%$, and $1 \%$ levels.

\begin{tabular}{|c|c|c|c|c|c|c|}
\hline \multirow[t]{2}{*}{ Dependent Variable: } & \multicolumn{2}{|c|}{ Worker Ex Ante Earnings } & \multicolumn{2}{|c|}{ Worker Ex Post Earnings } & \multicolumn{2}{|c|}{ Worker Earnings Growth } \\
\hline & {$[1]$} & {$[2]$} & [3] & {$[4]$} & {$[5]$} & {$[6]$} \\
\hline Leverage & $\begin{array}{c}0.056 \\
(0.094)\end{array}$ & $\begin{array}{c}0.038 \\
(0.029)\end{array}$ & $\begin{array}{l}-0.032 \\
(0.032)\end{array}$ & $\begin{array}{l}-0.037 \\
(0.025)\end{array}$ & $\begin{array}{l}-0.033 \\
(0.031)\end{array}$ & $\begin{array}{c}-0.041 * \\
(0.024)\end{array}$ \\
\hline Leverage $\times$ IndDistress & $\begin{array}{c}0.862 * * \\
(0.413)\end{array}$ & $\begin{array}{c}0.481 * * * \\
(0.088)\end{array}$ & $\begin{array}{c}0.225^{* *} \\
(0.110)\end{array}$ & $\begin{array}{c}0.139 * * \\
(0.059)\end{array}$ & $\begin{array}{c}0.241 * * \\
(0.108)\end{array}$ & $\begin{array}{c}0.151 * * \\
(0.061)\end{array}$ \\
\hline Establishment Size & & $\begin{array}{c}-0.063 * * * \\
(0.008)\end{array}$ & & $\begin{array}{c}-0.034 * * * \\
(0.005)\end{array}$ & & $\begin{array}{c}-0.033^{* * *} \\
(0.005)\end{array}$ \\
\hline Establishment Mean Wage (Excl. Worker) & & $\begin{array}{c}0.869 * * * \\
(0.078)\end{array}$ & & $\begin{array}{c}0.147 * * * \\
(0.030)\end{array}$ & & $\begin{array}{c}0.144 * * * \\
(0.030)\end{array}$ \\
\hline Firm Age & & $\begin{array}{c}0.001 \\
(0.004)\end{array}$ & & $\begin{array}{l}-0.000 \\
(0.002)\end{array}$ & & $\begin{array}{l}-0.000 \\
(0.002)\end{array}$ \\
\hline Diversified Firm & & $\begin{array}{l}-0.059^{*} \\
(0.034)\end{array}$ & & $\begin{array}{c}-0.045^{* * *} \\
(0.017)\end{array}$ & & $\begin{array}{c}-0.049 * * * \\
(0.018)\end{array}$ \\
\hline Firm Sales Growth & & $\begin{array}{c}0.091 * * * \\
(0.025)\end{array}$ & & $\begin{array}{c}-0.018 * * \\
(0.009)\end{array}$ & & $\begin{array}{c}-0.018 * * \\
(0.008)\end{array}$ \\
\hline Firm Return on Assets & & $\begin{array}{l}-0.090 \\
(0.067)\end{array}$ & & $\begin{array}{c}-0.097 * \\
(0.054)\end{array}$ & & $\begin{array}{c}-0.103 * \\
(0.054)\end{array}$ \\
\hline Firm Investments & & $\begin{array}{l}0.133^{*} \\
(0.077)\end{array}$ & & $\begin{array}{c}0.240 * * * \\
(0.070)\end{array}$ & & $\begin{array}{c}0.240 * * * \\
(0.071)\end{array}$ \\
\hline Firm R\&D & & $\begin{array}{l}-0.084 \\
(0.161)\end{array}$ & & $\begin{array}{c}0.168 \\
(0.262)\end{array}$ & & $\begin{array}{c}0.068 \\
(0.269)\end{array}$ \\
\hline Firm Tobin's Q & & $\begin{array}{c}0.010 \\
(0.013)\end{array}$ & & $\begin{array}{c}0.004 \\
(0.011)\end{array}$ & & $\begin{array}{c}0.006 \\
(0.011)\end{array}$ \\
\hline Firm Size & & $\begin{array}{c}0.001 \\
(0.006)\end{array}$ & & $\begin{array}{l}-0.005 \\
(0.005)\end{array}$ & & $\begin{array}{l}-0.005 \\
(0.005)\end{array}$ \\
\hline Firm Asset Tangibility & & $\begin{array}{c}-0.074 \\
(0.062)\end{array}$ & & $\begin{array}{c}-0.080 * \\
(0.041)\end{array}$ & & $\begin{array}{c}-0.075^{*} \\
(0.039)\end{array}$ \\
\hline Firm Cash & & $\begin{array}{c}0.005 \\
(0.077)\end{array}$ & & $\begin{array}{l}-0.029 \\
(0.044)\end{array}$ & & $\begin{array}{l}-0.049 \\
(0.056)\end{array}$ \\
\hline Industry-Year FE & Yes & Yes & Yes & Yes & Yes & Yes \\
\hline State-Year FE & Yes & Yes & Yes & Yes & Yes & Yes \\
\hline $\begin{array}{l}\text { Worker Controls } \\
\text { Worker Ex Ante Earnings }\end{array}$ & Yes & Yes & $\begin{array}{l}\text { Yes } \\
\text { Yes }\end{array}$ & $\begin{array}{l}\text { Yes } \\
\text { Yes }\end{array}$ & $\begin{array}{l}\text { Yes } \\
\text { Yes }\end{array}$ & $\begin{array}{l}\text { Yes } \\
\text { Yes }\end{array}$ \\
\hline $\begin{array}{l}\text { R-squared } \\
\text { Number of Observations }\end{array}$ & $\begin{array}{c}0.410 \\
315,200\end{array}$ & $\begin{array}{c}0.458 \\
315,200\end{array}$ & $\begin{array}{c}0.231 \\
315,200\end{array}$ & $\begin{array}{c}0.235 \\
315,200\end{array}$ & $\begin{array}{c}0.393 \\
315,200\end{array}$ & $\begin{array}{c}0.396 \\
315,200\end{array}$ \\
\hline
\end{tabular}




\section{Table 3.9: The Effect of Firm Financial Distress on the Quality of Startups}

This table presents startup-level analysis. The sample consists of start-ups founded by workers who exit establishments of U.S. public firms from 1990 through 2003. Startup Exit is an indicator variable equal to one if a start-up exits by the fifth year since it became identified with the entrepreneur. Startup Future Empl is the natural logarithm of startup employment plus one in five years since it became identified with the entrepreneur. Startup Empl Growth is the log-difference between start-up future and initial employments. Establishment- and firm-level control variables are measured at a public firm level. Worker-level control variables include worker age, worker age squared, female indicator, white indicator, worker foreign born indicator, worker in-state born indicator, worker education, worker total experience, and worker tenure. Startup-level control variables include startup age at the time it became identified with the entrepreneur and startup initial employment. Table A.8 in the Appendix provides estimates of the coefficients on worker and start-up control variables. Detailed variable definitions are in the Appendix A. Standard errors are clustered at the SIC-3 code industry-level and are in parentheses. *, **, and *** denote significance at the $10 \%, 5 \%$, and $1 \%$ levels.

\begin{tabular}{|c|c|c|c|c|c|c|}
\hline \multirow[t]{2}{*}{ Dependent Variable: } & \multicolumn{2}{|c|}{ Startup Exit } & \multicolumn{2}{|c|}{ Startup Future Empl } & \multicolumn{2}{|c|}{ Startup Empl Growth } \\
\hline & {$[1]$} & {$[2]$} & {$[3]$} & {$[4]$} & {$[5]$} & {$[6]$} \\
\hline Leverage & $\begin{array}{c}0.006 \\
(0.006)\end{array}$ & $\begin{array}{c}0.011 \\
(0.007)\end{array}$ & $\begin{array}{c}0.023 \\
(0.020)\end{array}$ & $\begin{array}{c}0.007 \\
(0.021)\end{array}$ & $\begin{array}{c}0.026 \\
(0.021)\end{array}$ & $\begin{array}{c}0.012 \\
(0.021)\end{array}$ \\
\hline Leverage $\times$ IndDistress & $\begin{array}{c}-0.052 * * \\
(0.024)\end{array}$ & $\begin{array}{l}-0.039 \\
(0.025)\end{array}$ & $\begin{array}{c}0.198 * * * \\
(0.064)\end{array}$ & $\begin{array}{c}0.166^{* *} \\
(0.067)\end{array}$ & $\begin{array}{c}0.172 * * * \\
(0.062)\end{array}$ & $\begin{array}{c}0.143^{* *} \\
(0.064)\end{array}$ \\
\hline Worker Ex Ante Earnings & $\begin{array}{c}-0.013 * * * * \\
(0.002)\end{array}$ & $\begin{array}{c}-0.012 * * * \\
(0.002)\end{array}$ & $\begin{array}{c}0.087 * * * \\
(0.008)\end{array}$ & $\begin{array}{c}0.088 * * * \\
(0.007)\end{array}$ & $\begin{array}{c}0.083 * * * \\
(0.007)\end{array}$ & $\begin{array}{c}0.084 * * * \\
(0.007)\end{array}$ \\
\hline Establishment Size & & $\begin{array}{l}0.002 * \\
(0.001)\end{array}$ & & $\begin{array}{c}-0.016 \text { *** } \\
(0.004)\end{array}$ & & $\begin{array}{c}-0.015 * * * \\
(0.004)\end{array}$ \\
\hline Establishment Mean Wage (Excl. Worker) & & $\begin{array}{c}-0.010 * * * \\
(0.003)\end{array}$ & & $\begin{array}{l}-0.015 \\
(0.014)\end{array}$ & & $\begin{array}{l}-0.019 \\
(0.013)\end{array}$ \\
\hline Firm Age & & $\begin{array}{c}-0.001 * * * \\
(0.000)\end{array}$ & & $\begin{array}{c}0.001 \\
(0.001)\end{array}$ & & $\begin{array}{c}0.001 \\
(0.001)\end{array}$ \\
\hline Diversified Firm & & $\begin{array}{c}-0.001 \\
(0.007)\end{array}$ & & $\begin{array}{c}-0.002 \\
(0.020)\end{array}$ & & $\begin{array}{c}0.001 \\
(0.019)\end{array}$ \\
\hline Firm Sales Growth & & $\begin{array}{l}-0.007 \\
(0.006)\end{array}$ & & $\begin{array}{c}0.023 \\
(0.015)\end{array}$ & & $\begin{array}{c}0.029 * * \\
(0.013)\end{array}$ \\
\hline Firm Return on Assets & & $\begin{array}{c}0.011 \\
(0.015)\end{array}$ & & $\begin{array}{c}-0.078^{*} \\
(0.044)\end{array}$ & & $\begin{array}{c}-0.077^{*} \\
(0.045)\end{array}$ \\
\hline Firm Investments & & $\begin{array}{l}0.027 * \\
(0.016)\end{array}$ & & $\begin{array}{c}0.047 \\
(0.055)\end{array}$ & & $\begin{array}{c}0.057 \\
(0.056)\end{array}$ \\
\hline Firm R\&D & & $\begin{array}{c}0.165^{* * *} \\
(0.051)\end{array}$ & & $\begin{array}{l}-0.043 \\
(0.204)\end{array}$ & & $\begin{array}{l}-0.000 \\
(0.189)\end{array}$ \\
\hline Firm Tobin's Q & & $\begin{array}{c}-0.001 \\
(0.003)\end{array}$ & & $\begin{array}{c}-0.005 \\
(0.011)\end{array}$ & & $\begin{array}{c}-0.006 \\
(0.011)\end{array}$ \\
\hline Firm Size & & $\begin{array}{c}0.003 * * * \\
(0.001)\end{array}$ & & $\begin{array}{c}-0.006^{* *} \\
(0.003)\end{array}$ & & $\begin{array}{c}-0.005^{* *} \\
(0.003)\end{array}$ \\
\hline Firm Asset Tangibility & & $\begin{array}{l}-0.006 \\
(0.009)\end{array}$ & & $\begin{array}{l}-0.037 \\
(0.024)\end{array}$ & & $\begin{array}{c}-0.034 \\
(0.024)\end{array}$ \\
\hline Firm Cash & & $\begin{array}{c}0.002 \\
(0.023)\end{array}$ & & $\begin{array}{l}-0.049 \\
(0.060)\end{array}$ & & $\begin{array}{l}-0.046 \\
(0.052)\end{array}$ \\
\hline Industry-Year FE & Yes & Yes & Yes & Yes & Yes & Yes \\
\hline State-Year FE & Yes & Yes & Yes & Yes & Yes & Yes \\
\hline Worker Controls & Yes & Yes & Yes & Yes & Yes & Yes \\
\hline Startup Controls & Yes & Yes & Yes & Yes & Yes & Yes \\
\hline R-squared & 0.021 & 0.022 & 0.038 & 0.038 & 0.075 & 0.076 \\
\hline Number of Observations & 315,200 & 315,200 & 315,200 & 315,200 & 315,200 & 315,200 \\
\hline
\end{tabular}




\subsection{Robustness Checks and Interpretation}

In this section I summarize several supplemental analyses that test the robustness of the results and interpretation. One potential explanation of the results is that new firms are sales of establishments from distressed firms to former employees or firm-initiated spin-offs. This explanation is unlikely to drive the results. First, the definition of a new firm controls for the possibility of a transfer from one entity to another; only newly-created establishments are defined as firm births. Second, when I exclude establishments from which more than $50 \%$ of employees move to startups, I get similar results (see Table A.5 in the Appendix).

The sample is not restricted to stand-alone firms because few public firms have establishments in only one industry (see Table 2.1). Thus, one possible interpretation is that establishments in industries that represent a small percentage of total firm employment might disproportionally affect the results, possibly because firms in distress are more likely to reduce activity in economically small industries. When industries that represent less than $10 \%$ of firm employment are excluded, the results are unchanged (see Table A.5 in the Appendix).

I explore whether the main results are sensitive to using alternative definitions of financial leverage. I use book rather than market leverage ratio to avoid potential negative bias associated with the firm market equity forecasting low investment opportunities (see section 2 for the discussion). When the two-year lagged market financial leverage is used, I indeed obtain lower but still significant estimates of the interaction between ex ante leverage and industry distress (see Table A.6 in the Appendix). Additionally, the book leverage is redefined as long-term debt over book assets, excluding current liabilities from the numerator. This might be a better definition of financial leverage if a firm's decision to refinance debt in current liabilities depended on the perception

of investment opportunities. The results are similar to the main results and are in Table A.6 in the Appendix.

I also verify that the results are driven by firms that have relatively high interest payments. Redefining financial leverage as two-year lagged interest expense normalized by two-year lagged assets or sales yields similar results. That stability suggests that when hit by a shock, firms with 
relatively high interest expense obligations are more affected because they have to allocate a greater share of their sparse cash flows to paying debt holders. Additionally, the main results are robust to using net financial leverage ratio, which is adjusted for cash and short-term securities, implying that more levered firms that hoard cash in anticipation of a shock are unlikely to drive higher entrepreneurship following shocks (see Table A.6 in the Appendix).

\subsection{External Validity}

In this section, I discuss the generalization of the results presented in this dissertation. The sample consists of public firms. Given that most firms are private, one might question whether the results extend to a broader set of firms. By excluding private firms, my estimates likely underestimate the extent of employee entrepreneurship in financially distressed firms. Public firms are likely to have lower costs of financial distress because they have better access to capital and because private firms are more financially levered than public firms (Asker, Farre-Mensa, and Ljungqvist (2011); Farre-Mensa and Ljungqvist (2013)). Additionally, most young firms are private and recent evidence on the capital structure of young firms suggests that they are relatively more levered than public firms. Robb and Robinson (2014) report that an average leverage ratio of start-ups is around $50 \%$ (personal debt plus business debt over total capital), twice that of public firms in the sample (average book and market leverage ratios are $25.5 \%$ and $24 \%$, respectively), suggesting that younger firms might be more vulnerable to economic shocks and therefore less able to retain entrepreneurial employees.

Another potential difficulty in generalizing the results is a concern that they are driven by high tech firms that were most affected by the dot-com bubble, the timing of which overlaps with the data used in this study. While high tech firms are probably more likely to experience employee entrepreneurship during financial distress due to higher growth opportunities, high tech firms are also less likely to use debt in their capital structure. Nevertheless, when I split industries into high tech vs. non-high tech following the definition in Ouimet and Zarutskie (2014), and do triple difference estimation using equation 4.1, I find the effect in non-tech industries as well (see Table A.10 in the Appendix for the regression results). Additionally, cross-sectional tests show that 
workers also exit older distressed firms to found start-ups, suggesting that firms that went public because of the bubble are not the main drivers of the results. In summary, the evidence suggests that tech-bubble firms are less likely to be the main driver of the results.

To identify financial distress this dissertation relies on episodes of industry declines. Employment opportunities with existing firms are likely to be sparse during these periods, potentially making the entrepreneurship option relatively more attractive. However, the lack of employment opportunities during industry distress cannot fully explain higher worker entrepreneurship in financially distressed firms. First, I directly control for employment opportunities by including industry-year fixed effects. Second, contrary to this argument, following industry distress, workers are not more likely to move to start-ups (coefficient on IndDistress is zero for an average leverage firm, when I use any of my entrepreneurship variables as a dependent variable).

The coverage of the LEHD data used in this study extends to only 25 states. This incomplete coverage likely works against finding the results, especially since the sample excludes the most entrepreneurial states such as California and Massachusetts (Gompers et al. (2005)). Another concern with the incomplete coverage is that some workers in a sample might drop out because they move to a non-covered state. I believe this does not introduce a bias in the measurement of entrepreneurship during financial distress. First, the results are robust to normalizing the number of entrepreneurs by the total number of workers who leave the company. Second, the results do not change when I include state-year fixed effects, making it less likely that the financial distress of firms is geographically concentrated and correlated with worker movement in and out of state.

Lastly, since the LBD covers only employer firms and does not include Schedule C selfemployed activity, the analysis is limited to the formation of employer firms. As such, the commencement of Schedule C self-employed activity is unmeasured and is not considered to be entrepreneurship in this sample. However, I do not find that workers are more likely to drop out from the employer firms sample following firm distress, suggesting that the self-employed group does not increase. 


\section{CHAPTER 4: POTENTIAL CHANNELS}

The empirical findings so far illustrate that during industry downturns, firm financial leverage affects the rate and the quality of entrepreneurial spawning. Following periods of firm financial distress, more workers exit to found new firms, entrepreneurs from financially distressed firms are high-quality workers, and their start-ups have high future employment growth.

This section discusses potential explanations for the findings. During economic shocks, financial leverage can exacerbate many frictions; therefore, multiple and non-mutually exclusive potential stories can arise. I first present a hypothesis relying on a positive selection of workers into entrepreneurship and provide empirical evidence aimed at testing this story. I next discuss several other hypotheses, followed by the discussion.

\subsection{Hypotheses}

\section{Brain Drain Hypothesis}

This hypothesis is based on incomplete contracting literature (Grossman and Hart (1986); Hart and Moore (1990); Berk et al. (2010)). While using debt financing might be optimal ex ante, given tax and other benefits of debt, having debt makes contracting more difficult during a negative shock. Workers might not want to deal with a financially weak firm, since such a firm provides lower job security and has poor incentives to honor contracts (Titman (1984); Maksimovic and Titman (1991)). During shocks, relatively more levered firms might also face tighter financing constraints and be less able to obtain external funding to alleviate contracting difficulties. Higherquality workers with good ideas for new products or services might be unwilling to develop them within the financially distressed firm and be particularly inclined to leave, causing a "brain drain" (Lucas (1978)).

The Census data do not include information about workers' motivations for starting a firm; I can therefore test this story only indirectly. The results of my entrepreneur and start-up quality 
analyses are consistent with this hypothesis. However, this hypothesis also relies on the assumption that firms in financial distress do not have ex ante contractual means to discourage their workers from starting competing new firms. I verify that this assumption is relevant since, following industry distress, the entrepreneurs from more financially levered firms are not more likely to switch industries. $^{1}$

One of the standard ways for firms to hold onto employees is through non-compete agreements, which place constraints on the employees' post-separation freedom. In particular, by signing these agreements, employees are contractually restricted from joining or establishing a competing firm for a specified period of time, usually two to three years. Firms use non-compete agreements to protect their proprietary knowledge or technology, client lists, and other intangible assets from being used by the departed workers. Non-compete agreements are commonplace in employment contracts and are particularly relevant for high human capital workers. Since an employer can sue a former employee for pursuing related economic activity, these contracts raise workers' opportunity cost of leaving the employer. Using a random sample of 500 Execucomp firms, Garmaise (2009) estimates that at least $70 \%$ of firms use non-compete agreements with their top executives. This estimate is consistent with the frequency of non-compete provisions in contracts with entrepreneurs (Kaplan and Strömberg (2003)) and technology workers (Jauhiainen, Heilmann, and Hurmelinna (2003)).

While non-compete agreements are commonplace in all U.S. states, significant inter-state variation exists in the degree of their enforcement. For example, such agreements are void in California but are very strictly enforced in Florida. The degree to which they are enforced was found to restrict worker movement across firms (Fallick, Fleischman, and Rebitzer (2006); Marx, Strumsky, and Fleming (2009); Marx (2011); Garmaise (2009)) and deter workers from entrepreneurial activity (Samila and Sorenson (2011); Marx (2011)). Thus, if a financially distressed employer is less

\footnotetext{
${ }^{1}$ I estimate Equation 3.1, where the dependent variable is an indicator variable equal to one if an SIC-2 industry of the start-up and the spawning establishment is the same (variable "Startup Same Ind"). The results are in Table A.9 in the Appendix. While the coefficient on leverage is positive and significant, the interaction term between firm leverage and industry distress is not significant. The results are similar if I use the SIC-1 or SIC-3 industry level.
} 
able to enforce these ex ante contracts, then workers are more likely to leave to found start-ups.

I test whether worker-entrepreneurship in financially distressed firms is higher in states that less strictly enforce these contracts. I obtain data on the enforceability of non-compete agreements from Garmaise (2009), who constructs a Noncompetition Enforceability Index for states from 1992 to $2004 .^{2}$ The index ranges from 0 for states that do not enforce the agreements, to 9 for states that enforce the agreements the most. I define an indicator variable, Low Enforceability NonCompetes, as equal to one for establishments in states whose index value is less than 5 , the median value of the index. A second indicator variable, High Enforceability Non-Competes, is defined as equal to one for establishments in states whose index value is 5 and above. Using the median value splits observations into two roughly equal groups (57.5\% in high enforceability and $42.5 \%$ in low enforceability). ${ }^{3}$ I estimate the following model at the establishment level:

$$
\begin{aligned}
y_{\text {efist }+3} & =\beta_{I} \times \text { IndDistress }_{i t}+\beta_{L} \times \text { Leverage }_{f t-2}+\alpha_{i e}+\alpha_{\text {st }} \\
& +\boldsymbol{\beta}_{\boldsymbol{F D} \boldsymbol{D}}^{\text {Low }} \times \text { Leverage }_{f t-2} \times \text { IndDistress }_{i t} \times \text { Low }+\gamma^{\prime} X_{\text {efist }} \\
& +\boldsymbol{\beta}_{\boldsymbol{F} \boldsymbol{D} \boldsymbol{\text { igh }}} \times \text { Leverage }_{f t-2} \times \text { IndDistress }_{i t} \times \text { High }+\epsilon_{\text {efist }}
\end{aligned}
$$

All variables are as defined in Equation 2.1 with the exception of $\alpha_{i e}$, which is industry-year and/or establishment fixed effects, and High (Low), which is High (Low) Enforceability NonCompetes indicator variable. In addition to other control variables used in the main specification, $X$ now also includes High (indicator variable High Enforceability Non-Competes) and interactions of High with leverage and industry distress.

I present the results in Table 4.1. I find that the worker entrepreneurship in financially distressed firms is driven by establishments in states that less strictly enforce non-compete agreements. The estimate of $\beta_{\text {high }}$ is higher than that of $\beta_{\text {low }}$ in every specification, and the difference between $\beta_{\text {high }}$ and $\beta_{\text {low }}$ is statistically significant. The evidence suggests that when financially weak firms are

\footnotetext{
${ }^{2}$ For 1990 and 1991, I back-fill the values of the index from 1992.

${ }^{3}$ Changing the threshold by one (High Enforceability Non-Competes equal to one for values of 6 and above) makes the difference between high and low enforceability states more pronounced.
} 
less able to use ex ante contractual means to discourage their workers from starting competing new firms, worker exit to found new firms accelerates.

Another assumption underlying this story is that firms in financial distress are less able to access external capital markets during negative shocks, and to obtain funds to retain workers. Thus, I look at a subset of firms that are particularly likely to have limited access to external capital and that face tighter financing constraints. One of the most important determinants of financial constraints is the degree of information asymmetry between a firm and the capital market (Leland and Pyle (1977); Myers and Majluf (1984)). Bigger and older, more established firms are likely to be characterized by a lower degree of information asymmetry and lower costs of external financing (Hadlock and Pierce (2010); Li (2011)). Thus, I identify smaller and younger firms as likely to face greater financial constraints.

I use total firm assets as a proxy for firm size and age as a public firm to measure the length of the relationship with capital markets. For firm size, I sort firms each year into two groups based on the median value of one-year lagged assets: firms with expected higher level of financial constraints (smaller firms) and those with expected lower levels (larger firms). I then define indicator variables for each category. For public firm age, I define an indicator variable for relatively young public firms, those that underwent an IPO within the past five years. These firms have a short history with capital markets and hence are likely to be more constrained. I define another indicator variable for older firms that have been around as public firms for more than five years. I estimate a triple difference model using equation 4.1. If financial constraints are important in retaining workers, then we expect employee-entrepreneurship to be more pronounced in smaller and younger financially distressed firms.

Table 4.2 presents the results. Columns [1] - [2] show the results for firm size. Employee entrepreneurship is higher in smaller financially distressed firms. The estimate of $\beta_{\text {high }}$ is also significantly different from $\beta_{\text {low }}$. Columns [3] - [4] show the results for firm age. Employee entrepreneurship is higher in younger financially distressed firms, but the difference from the older firms is not statistically significant, potentially reflecting a low fraction of observations in younger 
firms (about $15 \%$ of all observations). Taken together, the results in Table 4.2 suggest that financially distressed firms are financially constrained to retain entrepreneurial workers.

Combined with the results on entrepreneur wages and start-up performance, the evidence presented in this section suggests that relatively more levered firms might be less able to retain highquality workers following industry shocks. These workers exit to found new firms when their employers are more financially constrained and are also less able to enforce ex ante contracts aimed to discourage their workers from starting competing new firms. 


\section{Table 4.1: The Enforceability of Non-compete Agreements and Worker Departures to En- trepreneurship from Financially Distressed Firms}

This table presents establishment-level analysis. The sample consists of establishments of U.S. public firms, and extends from 1990 through 2003. The dependent variable Pct Entrepreneurs is the count of an establishment's workers defined as future entrepreneurs two years after the base year (the year during which distress is defined), normalized by base year establishment employment and expressed in percentage terms; a worker is a future entrepreneur if, two years after the base year, he works at a start-up (a firm founded during or after the base year) and is also one of the top five earners at that start-up. IndDistress is an indicator variable equal to one if an industry-year is in distress. Leverage is the firm book financial leverage ratio (long-term debt plus debt in current liabilities, normalized by total firm assets) lagged by two years from the base year. Low (High) Enforceability Non-competes is an indicator variable equal to one for establishments in states with the Noncompetition Enforceability Index value less than (greater or equal to) the median value of the index, which is from Garmaise (2009). Non-compete agreements are employment contracts restricting worker mobility to competing firms. All columns include leverage, industry distress indicator, as well as indicator variable High Enforceability Non-Competes and its interactions with leverage and industry distress. Establishment controls include establishment size and average worker wage. Firm controls are firm age, diversification, and the following financial variables lagged by one year: sales growth, return on assets, investments, R\&D expenses, Tobin's $\mathrm{Q}$, firm size, asset tangibility, and cash holdings. Detailed variable definitions are in the Appendix A. Standard errors are clustered at the SIC-3 code industry-level and are in parentheses. ${ }^{*},{ }^{* *}$, and ${ }^{* * *}$ denote significance at the $10 \%$, $5 \%$, and $1 \%$ levels.

\begin{tabular}{|c|c|c|c|c|c|c|}
\hline \multirow[t]{2}{*}{ Dependent Variable: } & \multicolumn{6}{|c|}{ Pct Entrepreneurs } \\
\hline & {$[1]$} & {$[2]$} & {$[3]$} & {$[2]$} & {$[3]$} & {$[4]$} \\
\hline Leverage $\times$ IndDistress $\times$ Low Enforceability Non-competes & $\begin{array}{c}2.315^{* * *} * \\
(0.685)\end{array}$ & $\begin{array}{c}2.458 * * * \\
(0.824)\end{array}$ & $\begin{array}{c}3.207 * * * \\
(1.123)\end{array}$ & $\begin{array}{c}3.196^{* * * *} \\
(1.102)\end{array}$ & $\begin{array}{c}3.058 * * * \\
(1.151)\end{array}$ & $\begin{array}{c}3.047 * * * \\
(1.143)\end{array}$ \\
\hline Leverage $\times$ IndDistress $\times$ High Enforceability Non-competes & $\begin{array}{c}0.399 \\
(0.371)\end{array}$ & $\begin{array}{c}0.446 \\
(0.505)\end{array}$ & $\begin{array}{c}1.100 * * * \\
(0.348)\end{array}$ & $\begin{array}{c}1.115^{* * * *} \\
(0.337)\end{array}$ & $\begin{array}{c}0.979 * * \\
(0.445)\end{array}$ & $\begin{array}{c}0.996 * * \\
(0.444)\end{array}$ \\
\hline Industry-Year FE & Yes & Yes & & & Yes & Yes \\
\hline State-Year FE & Yes & Yes & Yes & Yes & Yes & Yes \\
\hline Establishment FE & & & Yes & Yes & Yes & Yes \\
\hline Establishment Controls & & Yes & & Yes & & Yes \\
\hline Firm Controls & & Yes & & Yes & & Yes \\
\hline R-squared & 0.028 & 0.035 & 0.512 & 0.512 & 0.520 & 0.521 \\
\hline Number of Observations & 91,100 & 91,100 & 91,100 & 91,100 & 91,100 & 91,100 \\
\hline F-test (difference) & 9.990 & 11.732 & 3.585 & 3.525 & 2.971 & 2.898 \\
\hline p-val (difference) & 0.002 & 0.001 & 0.060 & 0.062 & 0.087 & 0.091 \\
\hline
\end{tabular}


Table 4.2: The Effect of Firm Financial Constraints on the Ability of Firms to Retain Entrepreneurial Workers

This table presents establishment-level analysis. The sample consists of establishments of U.S. public firms, and extends from 1990 through 2003. The dependent variable Pct Entrepreneurs is the count of an establishment's workers defined as future entrepreneurs two years after the base year (the year during which distress is defined), normalized by base year establishment employment and expressed in percentage terms; a worker is a future entrepreneur if, two years after the base year, he works at a start-up (a firm founded during or after the base year) and is also one of the top five earners at that start-up. IndDistress is an indicator variable equal to one if an industry-year is in distress. Leverage is the firm book financial leverage ratio (long-term debt plus debt in current liabilities, normalized by total firm assets) lagged by two years from the base year. Small (Large) Firm is an indicator variable equal to one for establishments of firms with total assets below (above or equal to) the median firm's assets. Young (Old) Firm is an indicator variable equal to one for establishments of firms in Compustat for five years or fewer (more than five years). All columns include leverage and industry distress indicator. Columns [1] - [2] ([3] - [4]) include an indicator variable Large (Old) Firm and its interactions with leverage and industry distress. Establishment controls include establishment size and average worker wage. Firm controls are firm age, diversification, and the following financial variables lagged by one year: sales growth, return on assets, investments, R\&D expenses, Tobin's Q, firm size, asset tangibility, and cash holdings. Detailed variable definitions are in the Appendix A. Standard errors are clustered at the SIC-3 code industry-level and are in parentheses. ${ }^{*},{ }^{* *}$, and ${ }^{* * *}$ denote significance at the $10 \%, 5 \%$, and $1 \%$ levels.

\begin{tabular}{|c|c|c|c|c|}
\hline \multirow[t]{2}{*}{ Dependent Variable: } & \multicolumn{4}{|c|}{ Pct Entrepreneurs } \\
\hline & {$[1]$} & {$[2]$} & {$[3]$} & {$[4]$} \\
\hline Leverage $\times$ IndDistress $\times$ Small Firm & $\begin{array}{c}3.681 * * * \\
(1.325)\end{array}$ & $\begin{array}{c}3.701 * * * \\
(1.317)\end{array}$ & & \\
\hline Leverage $\times$ IndDistress $\times$ Large Firm & $\begin{array}{c}0.703 \\
(0.484)\end{array}$ & $\begin{array}{c}0.704 \\
(0.477)\end{array}$ & & \\
\hline Leverage $\times$ IndDistress $\times$ Young Firm & & & $\begin{array}{c}3.449 * * * \\
(1.193)\end{array}$ & $\begin{array}{c}3.381 * * * \\
(1.190)\end{array}$ \\
\hline Leverage $\times$ IndDistress $\times$ Old Firm & & & $1.547 * *$ & $1.568 * *$ \\
\hline & & & $(0.618)$ & $(0.611)$ \\
\hline Industry-Year FE & Yes & Yes & Yes & Yes \\
\hline State-Year FE & Yes & Yes & Yes & Yes \\
\hline Establishment FE & Yes & Yes & Yes & Yes \\
\hline Establishment Controls & & Yes & & Yes \\
\hline Firm Controls & & Yes & & Yes \\
\hline R-squared & 0.520 & 0.521 & 0.520 & 0.521 \\
\hline Number of Observations & 91,100 & 91,100 & 91,100 & 91,100 \\
\hline F-test (difference) & 4.573 & 4.701 & 2.079 & 1.911 \\
\hline p-val (difference) & 0.034 & 0.032 & 0.151 & 0.169 \\
\hline
\end{tabular}




\section{Other Mechanisms}

Asset Appropriation Hypothesis. This hypothesis is based on a property rights view of the theory of the firm (Grossman and Hart (1986); Hart and Moore (1990)). A firm is organized around nonhuman assets, and employees do not have ownership rights to these assets. The underlying assumption is that the firm has legal protection of its asset ownership and that its workers cannot appropriate those assets. However, the firm's ability to protect its assets depends on the financial resources available to litigate. During financial distress, the cash flow available to the firm shrinks and external financing becomes more expensive. Thus, the firm might become less financially able to protect its existing assets, particularly intangible assets, the theft of which is more difficult to prove and hence more expensive to litigate. Workers might perceive the financial weakness of their employer and use the opportunity to appropriate the distressed employer's assets in a new firm. ${ }^{4}$

For this story to hold, the rate of entrepreneurship in distressed firms should be higher in states that more strictly enforce non-compete agreements. This prediction follows because financial ability to litigate a former employee for appropriating intangible assets should matter more in states where firms can take the workers to court for competing activities. Since I find the opposite, it is less likely that workers found start-ups to appropriate existing intangible assets of the employer.

Agency cost. Since financial distress can exacerbate agency problems inside the firm due to separation of control and ownership, the next hypothesis is based on agency costs arising due to managerial career concerns (Holmström (1999)). The principal-agent problem occurs between the shareholder and the manager who derives private benefit from keeping his job. The manager bears career risk when investments in promising but risky new ideas do not pan out due to poor luck, but shareholders mistakenly attribute the failure to poor manager ability. Since investing in risky projects during financial distress increases the risk of firm failure and job loss, the manager passes on profitable but risky projects when the firm experiences financial distress. These rejected projects can then be developed in start-ups. For this story to make intuitive sense, one must assume that

\footnotetext{
${ }^{4}$ Almeling, Snyder, and Sapoznikow (2009) report that, among legal cases involving trade secrets, the misappropriation of intellectual property by former employees is the most common.
} 
would-be entrepreneurs are less risk averse than the manager. Given that the manager is likely to be wealthier and hence less risk averse than the workers, this assumption seems strong. Thus, it is unlikely that the higher rates of worker entrepreneurship following firm financial distress are due to this story.

\subsection{Discussion}

Overall, I find that financial distress propels high-quality workers into entrepreneurship, but mostly when firms are less able to enforce ex ante contracts discouraging the workers from pursuing related economic activity. The results are consistent with the "brain drain" hypothesis that suggests that high-quality workers leave financially distressed firms to found start-ups to develop their ideas. That said, the evidence is suggestive. Other stories might explain why financial distress spurs entrepreneurship.

While the cross-sectional tests seem to support the "brain drain" hypothesis, the ability of workers to fund their start-ups remains puzzling, particularly following industry downturns when funding is likely limited. If the results are driven by industries that require considerable initial capital, such as manufacturing, it is hard to explain why entrepreneurs can fund their ideas better than public firms. I analyze whether employee-entrepreneurs exiting firms in financial distress are more likely to come from industries with lower start-up costs. I find that, indeed, the effect is more prevalent in industries with lower start-up capital requirements (see Table A.10 in the Appendix for the regression results).

A related question asks why potential entrepreneurs do not get financing from other existing firms. A fundamental problem in a market for ideas is that disclosing the idea exposes the worker to the risk of expropriation because intellectual property rights protection is not perfect (Arrow (1962)). Another firm's willingness to fund depends on knowing the idea's value, but the worker might be reluctant to reveal the idea for the fear of it being stolen and instead might prefer to found a start-up. Even respectful firms were known to appropriate ideas from entrepreneurs. Unable to commercialize on his own, Robert Kearns, an independent inventor of the intermittent windshield 
wiper, approached the Ford Motor Company in the early 1960s. After some negotiation, Ford rejected a licensing agreement with Kearns but introduced a similar technology to the market shortly thereafter. Kearns had a patent, but it was not until the 1990s that he successfully upheld his patent and extracted a portion of the economic returns (Gans and Stern (2003)). Furthermore, many ideas for new products or services are not patentable. Kearns' case suggests that sharing non-patentable ideas with potential outside investors involves even higher risk. 


\section{CHAPTER 5: CONCLUSION}

In this dissertation, I identify an important but largely overlooked effect of firm financial leverage on new firm creation. My findings show that financial leverage, by making firms more vulnerable in bad states of the world, weakens firm-worker ties and propels workers to start their own firms. This new firm creation is higher when firms are less able to enforce ex ante contracts that discourage workers from pursuing related economic activity. This "destructive creation" suggests that some new firms arise when existing firms, weakened by shocks and burdened by debt, are less able to retain entrepreneurial workers.

From the corporate finance perspective, this dissertation shows that firms' reluctance to use debt financing might stem from their wish to avoid losing productive workers to new firms during financial distress. While worker entrepreneurship does not likely benefit distressed firms, the findings suggest a silver lining to financial distress. Workers from financially distressed firms start successful new ventures at a higher rate, suggesting that productive resources get reallocated from old to new firms and that the social costs of financial distress might be lower than the private costs to financially distressed firms. Firms do not exist in a vacuum. If firms in financial distress forgo good investment opportunities, employees might still pursue those opportunities, but within the boundaries of new firms.

This dissertation contributes to the recent discussion concerning the slow down in new firm creation and labor turnover over the past 30 years in the U. S. (Davis and Haltiwanger (2014); Decker, Haltiwanger, Jarmin, and Miranda (2014)). The results in this dissertation suggest that, to the extent that firms can learn how to better weather financial shocks and hence better retain workers, fewer new firms might not necessarily be an economically undesirable outcome. Without understanding the reasons for the decline in start-ups, it is difficult to argue that the drop in start-up creation is a bad trend. 
By providing evidence that employee entrepreneurship in financially distressed firms is driven by smaller and younger firms, this dissertation also provides a novel explanation for why smaller and younger firms spawn more start-ups. The existing literature argues that preference sorting plays a major role in generating the small and young firm effect; i.e., small and young firms attract workers with prior preferences for autonomy, who are similarly drawn into entrepreneurship (Elfenbein et al. (2010); Ouimet and Zarutskie (2014)). However, an alternative finance-oriented explanation centers around the finding that younger firms are more financially levered than public firms (Robb and Robinson (2014)). This higher leverage makes smaller, younger firms more vulnerable to shocks and less able to retain entrepreneurial employees.

Many successful firms are founded by people who leave paid employment. Yet, we know little about when and why workers leave their employers to create new firms or about the role of the employers in that decision. This dissertation is the first to show that capital structure decisions of existing firms have implications for new firm creation. We also know that a firm's venture capital connections and business focus are important factors in entrepreneurial spawning (Gompers et al. (2005)). Additionally, Babina, Ouimet, and Zarutskie (2015) find that IPO firms spur new firm creation by endowing employees with the capital necessary to pursue entrepreneurship. But much remains unknown about the roles of existing firms in new firm creation. Answering these questions has implications for our understanding of firm boundaries, economic growth, and occupational choices. 


\section{APPENDIX A: ROBUSTNESS}

\section{Table A.1: The Effect of Firm Financial Distress on Establishment Employment Growth}

This table presents establishment-level analysis. The sample consists of establishments of U.S. public firms, and extends from 1990 through 2003. The dependent variable Establishment Employment Growth is measured over the same period as the main entrepreneurship variable; it is defined in percentage terms and equals to the log-difference between three-year future and base year employments, both measured as of the first quarter. Base year is the year during which the distress is defined. IndDistress is an indicator variable equal to one if an industry-year is in distress. Leverage is the firm book financial leverage ratio (long-term debt plus debt in current liabilities, normalized by total firm assets) lagged by two years from the base year. Establishment controls include establishment size and average worker wage. Firm controls are firm age, diversification, and the following financial variables lagged by one year: sales growth, return on assets, investments, R\&D expenses, Tobin's Q, firm size, asset tangibility, and cash holdings. Detailed variable definitions are in the Appendix A. Standard errors are clustered at the SIC-3 code industry-level and are in parentheses. ${ }^{*},{ }^{* *}$, and ${ }^{* * *}$ denote significance at the $10 \%, 5 \%$, and $1 \%$ levels.

\begin{tabular}{lcccccc}
\hline Dependent Variable: & \multicolumn{7}{c}{ Establishment Employment Growth } \\
& {$[1]$} & {$[2]$} & {$[3]$} & {$[4]$} & {$[5]$} & {$[6]$} \\
\hline IndDistress & & & -2.675 & 0.237 & & \\
& & & $(7.203)$ & $(6.448)$ & & \\
Leverage & $-63.324^{* * *}$ & $-42.645^{* * *}$ & -0.652 & -2.206 & 4.026 & 1.554 \\
& $(10.039)$ & $(10.134)$ & $(13.178)$ & $(13.238)$ & $(12.770)$ & $(13.215)$ \\
Leverage $\times$ IndDistress & $-67.590^{* *}$ & $-59.487^{* *}$ & $-64.215^{* *}$ & $-64.498^{* *}$ & $-86.359^{* * * *}$ & $-85.485^{* * *}$ \\
& $(33.386)$ & $(29.025)$ & $(26.387)$ & $(26.345)$ & $(20.598)$ & $(19.729)$ \\
Industry-Year FE & Yes & Yes & & & Yes & Yes \\
State-Year FE & Yes & Yes & Yes & Yes & Yes & Yes \\
Establishment FE & & & Yes & Yes & Yes & Yes \\
Establishment Controls & & Yes & & Yes & & Yes \\
Firm Controls & & Yes & & Yes & & Yes \\
R-squared & 0.095 & 0.115 & 0.716 & 0.730 & 0.740 & 0.754 \\
Number of Observations & 91,100 & 91,100 & 91,100 & 91,100 & 91,100 & 91,100 \\
\hline
\end{tabular}




\section{Table A.2: Does Economic, not Financial, Distress Drive Entrepreneurship in Distressed Firms?}

This table presents establishment-level analysis. The sample consists of establishments of U.S. public firms, and extends from 1990 through 2003. The dependent variable Pct Entrepreneurs is the count of an establishment's workers defined as future entrepreneurs two years after the base year (the year during which the distress is defined), normalized by base year establishment employment and expressed in percentage terms; a worker is a future entrepreneur if, two years after the base year, he works at a start-up (a firm founded during or after the base year) and is also one of the top five earners at that start-up. IndDistress is an indicator variable equal to one if an industry-year is in distress. Leverage is the firm book financial leverage ratio (long-term debt plus debt in current liabilities, normalized by total firm assets) lagged by two years from the base year. Negative (Non-Negative) Oper Income is an indicator variable equal to one for firms with negative (non-negative) operating income (EBITDA) one year prior to the base year. All columns include leverage and industry distress indicator. Columns [1] - [4] include an indicator variable Negative Oper Income and its interactions with leverage and industry distress. Establishment controls include establishment size and average worker wage. Firm controls are firm age, diversification, and the following financial variables lagged by one year: sales growth, return on assets, investments, R\&D expenses, Tobin's Q, firm size, asset tangibility, and cash holdings. Detailed variable definitions are in the Appendix A. Standard errors are clustered at the SIC-3 code industry-level and are in parentheses. ${ }^{*},{ }^{* *}$, and ${ }^{* * *}$ denote significance at the $10 \%, 5 \%$, and $1 \%$ levels.

\begin{tabular}{|c|c|c|c|c|c|c|}
\hline \multirow[t]{2}{*}{ Dependent Variable: } & \multicolumn{6}{|c|}{ Pct Entrepreneurs } \\
\hline & {$[1]$} & {$[2]$} & {$[3]$} & {$[4]$} & {$[5]$} & {$[6]$} \\
\hline Leverage $\times$ IndDistress $\times$ Non-Negative Oper Income & $\begin{array}{c}1.355^{* * *} * \\
(0.491)\end{array}$ & $\begin{array}{c}1.313 * * \\
(0.588)\end{array}$ & $\begin{array}{c}1.788 * * * \\
(0.438)\end{array}$ & $\begin{array}{c}1.798 * * * \\
(0.423)\end{array}$ & $\begin{array}{c}1.675 * * * \\
(0.421)\end{array}$ & $\begin{array}{c}1.686^{* * * *} \\
(0.409)\end{array}$ \\
\hline Leverage $\times$ IndDistress $\times$ Negative Oper Income & $\begin{array}{c}0.652 \\
(1.630)\end{array}$ & $\begin{array}{c}0.809 \\
(1.553)\end{array}$ & $\begin{array}{c}3.270 \\
(2.711)\end{array}$ & $\begin{array}{c}3.275 \\
(2.759)\end{array}$ & $\begin{array}{c}2.966 \\
(2.903)\end{array}$ & $\begin{array}{c}2.966 \\
(2.958)\end{array}$ \\
\hline Industry-Year FE & Yes & Yes & & & Yes & Yes \\
\hline State-Year FE & Yes & Yes & Yes & Yes & Yes & Yes \\
\hline Establishment FE & & & Yes & Yes & Yes & Yes \\
\hline Establishment Controls & & Yes & & Yes & & Yes \\
\hline Firm Controls & & Yes & & Yes & & Yes \\
\hline R-squared & 0.029 & 0.035 & 0.512 & 0.513 & 0.520 & 0.521 \\
\hline Number of Observations & 91,100 & 91,100 & 91,100 & 91,100 & 91,100 & 91,100 \\
\hline F-test (difference) & 0.219 & 0.143 & 0.327 & 0.306 & 0.221 & 0.207 \\
\hline p-valt (difference) & 0.640 & 0.706 & 0.568 & 0.581 & 0.639 & 0.650 \\
\hline
\end{tabular}


Table A.3: The Effect of Firm Financial Distress on the Rate of Entrepreneurship Identified with Firm Fixed Effects

This table presents establishment-level analysis. The sample consists of establishments of U.S. public firms, and extends from 1990 through 2003. The dependent variable Pct Entrepreneurs is the count of an establishment's workers defined as future entrepreneurs two years after the base year (the year during which distress is defined), normalized by base year establishment employment and expressed in percentage terms; a worker is a future entrepreneur if, two years after the base year, he works at a start-up (a firm founded during or after the base year) and is also one of the top five earners at that start-up. IndDistress is an indicator variable equal to one if an industry-year is in distress. Leverage is the firm book financial leverage ratio (long-term debt plus debt in current liabilities, normalized by total firm assets) lagged by two years from the base year. Establishment controls include establishment size and average worker wage. Firm controls are firm age, diversification, and the following financial variables lagged by one year: sales growth, return on assets, investments, $R \& D$ expenses, Tobin's $Q$, firm size, asset tangibility, and cash holdings. Detailed variable definitions are in the Appendix A. Standard errors are clustered at the SIC- 3 code industry-level and are in parentheses. ${ }^{*},{ }^{* *}$, and ${ }^{* * *}$ denote significance at the $10 \%, 5 \%$, and $1 \%$ levels.

\begin{tabular}{lcccccc}
\hline Dependent Variable: & \multicolumn{5}{c}{ Pct Entrepreneurs } \\
& {$[1]$} & {$[2]$} & {$[3]$} & {$[4]$} & {$[5]$} & {$[6]$} \\
\hline IndDistress & $-0.271^{* * *}$ & $-0.306^{* * * *}$ & $-0.309^{* * *}$ & & & \\
& $(0.067)$ & $(0.067)$ & $(0.053)$ & & & \\
Leverage & -0.160 & -0.147 & -0.117 & -0.120 & -0.163 & -0.138 \\
& $(0.156)$ & $(0.156)$ & $(0.153)$ & $(0.158)$ & $(0.165)$ & $(0.166)$ \\
Leverage $\times$ IndDistress & $1.385^{* * *}$ & $1.481^{* * *}$ & $1.502^{* * *}$ & $1.417^{* * *}$ & $1.501^{* * *}$ & $1.505^{* * *}$ \\
& $(0.418)$ & $(0.422)$ & $(0.380)$ & $(0.420)$ & $(0.456)$ & $(0.430)$ \\
Industry FE & & Yes & Yes & & & \\
State-Year FE & & Yes & Yes & & Yes & Yes \\
Firm FE & Yes & Yes & Yes & Yes & Yes & Yes \\
Industry-Year FE & & & & Yes & Yes & Yes \\
Establishment Controls & & Yes & & Yes & & Yes \\
Firm Controls & & Yes & & Yes & & Yes \\
R-squared & 0.108 & 0.116 & 0.117 & 0.113 & 0.125 & 0.127 \\
Number of Observations & 91,100 & 91,100 & 91,100 & 91,100 & 91,100 & 91,100 \\
\hline
\end{tabular}


Table A.4: The Effect of Firm Financial Distress on the Rate of Entrepreneurship Among Departing Workers

This table presents establishment-level analysis. The sample consists of establishments of U.S. public firms, and extends from 1990 through 2003. The table reports the results with alternative normalization of future entrepreneurs. The dependent variable Pct Entrepreneurs/Leave is the count of an establishment's workers defined as future entrepreneurs two years after the base year (the year during which the distress is defined), normalized by the number of the establishment's employees who work for a different employer or who drop out from the employment sample two years after the base year, and expressed in percentage terms; a worker is a future entrepreneur if, two years after the base year, he works at a start-up (a firm founded during or after the base year) and is also one of the top five earners at that start-up. Leverage is the firm book financial leverage ratio (long-term debt plus debt in current liabilities, normalized by total firm assets) lagged by two years from the base year. Establishment controls include establishment size and average worker wage. Firm controls are firm age, diversification, and the following financial variables lagged by one year: sales growth, return on assets, investments, $R \& D$ expenses, Tobin's $Q$, firm size, asset tangibility, and cash holdings. Detailed variable definitions are in the Appendix A. Standard errors are clustered at the SIC- 3 code industry-level and are in parentheses. ${ }^{*},{ }^{* *}$, and ${ }^{* * *}$ denote significance at the $10 \%, 5 \%$, and $1 \%$ levels.

\begin{tabular}{lcccccc}
\hline Dependent Variable: & \multicolumn{5}{c}{ Pct Entrepreneurs/Leave } \\
& {$[1]$} & {$[2]$} & {$[3]$} & {$[4]$} & {$[5]$} & {$[6]$} \\
\hline IndDistress & & & $-0.848^{* * *}$ & $-0.849^{* * *}$ \\
& & & $(0.258)$ & $(0.234)$ & & \\
Leverage & 0.259 & 0.262 & -0.491 & -0.438 & -0.531 & -0.494 \\
& $(0.210)$ & $(0.186)$ & $(0.331)$ & $(0.344)$ & $(0.340)$ & $(0.356)$ \\
Leverage $\times$ IndDistress & $2.454^{* * *}$ & $2.620^{* *}$ & $2.887^{* *}$ & $2.888^{* *}$ & $2.961^{* *}$ & $2.981^{* *}$ \\
& $(0.823)$ & $(1.107)$ & $(1.221)$ & $(1.176)$ & $(1.329)$ & $(1.306)$ \\
Industry-Year FE & Yes & Yes & & & Yes & Yes \\
State-Year FE & Yes & Yes & Yes & Yes & Yes & Yes \\
Establishment FE & & & Yes & Yes & Yes & Yes \\
Establishment Controls & & Yes & & Yes & & Yes \\
Firm Controls & & Yes & & Yes & & Yes \\
R-squared & 0.025 & 0.028 & 0.459 & 0.459 & 0.468 & 0.468 \\
Number of Observations & 91,100 & 91,100 & 91,100 & 91,100 & 91,100 & 91,100 \\
\hline
\end{tabular}


Table A.5: The Effect of Firm Financial Distress on the Rate of Worker Entrepreneurship in Economically Significant Industries and Controlling for Firm-Initiated Spin-outs

This table presents establishment-level analysis. The sample consists of establishments of U.S. public firms, and extends from 1990 through 2003. The dependent variable Pct Entrepreneurs is the count of an establishment's workers defined as future entrepreneurs two years after the base year (the year during which the distress is defined), normalized by base year establishment employment and expressed in percentage terms; a worker is a future entrepreneur if, two years after the base year, he works at a start-up (a firm founded during or after the base year) and is also one of the top five earners at that start-up. IndDistress is an indicator variable equal to one if an industry-year is in distress. Leverage is the firm book financial leverage ratio (long-term debt plus debt in current liabilities, normalized by total firm assets) lagged by two years from the base year. Big Industry is an indicator variable equal to one when an establishment belongs to an industry that comprises at least ten percent of the firm total employment. No Spin-offs is an indicator variable equal to one when less than fifty percent of employees exit to work at start-ups two years after the base year. All columns include leverage and industry distress indicator. Establishment controls include establishment size and average worker wage. Firm controls are firm age, diversification, and the following financial variables lagged by one year: sales growth, return on assets, investments, R\&D expenses, Tobin's $\mathrm{Q}$, firm size, asset tangibility, and cash holdings. Detailed variable definitions are in the Appendix A. Standard errors are clustered at the SIC-3 code industry-level and are in parentheses. ${ }^{*},{ }^{* *}$, and ${ }^{* * *}$ denote significance at the $10 \%, 5 \%$, and $1 \%$ levels.

\begin{tabular}{lcccc}
\hline Dependent Variable: & \multicolumn{4}{c}{ Pct Entrepreneurs } \\
& {$[1]$} & {$[2]$} & {$[3]$} \\
\hline Leverage $\times$ IndDistress $\times$ Big Industry & $\begin{array}{c}1.771^{* * *} \\
\text { (0.390) }\end{array}$ & $\begin{array}{c}1.785^{* * *} \\
(0.382)\end{array}$ & & \\
Leverage $\times$ IndDistress $\times$ No Spin-offs & & & $1.685^{* *}$ & $1.692^{* *}$ \\
& & & $(0.657)$ & $(0.651)$ \\
Industry-Year FE & Yes & Yes & Yes & Yes \\
State-Year FE & Yes & Yes & Yes & Yes \\
Establishment FE & Yes & Yes & Yes & Yes \\
Establishment Controls & & Yes & & Yes \\
Firm Controls & & Yes & & Yes \\
R-squared & 0.520 & 0.520 & 0.520 & 0.520 \\
Number of Observations & 91,100 & 91,100 & 91,100 & 91,100 \\
\hline
\end{tabular}


Table A.6: The Effect of Firm Financial Distress on the Rate of Worker Entrepreneurship: Alternative Definitions of Financial Leverage

This table presents establishment-level analysis. The sample consists of establishments of U.S. public firms, and extends from 1990 through 2003. The dependent variable Pct Entrepreneurs is the count of an establishment's workers defined as future entrepreneurs two years after the base year (the year during which the distress is defined), normalized by base year establishment employment and expressed in percentage terms; a worker is a future entrepreneur if, two years after the base year, he works at a start-up (a firm founded during or after the base year) and is also one of the top five earners at that start-up. IndDistress is an indicator variable equal to one if an industry-year is in distress. Market Leverage is the firm market financial leverage ratio (long-term debt plus debt in current liabilities, normalized by total market value of firm assets) lagged by two years from the base year. Net Leverage is the firm net book financial leverage ratio (long-term debt plus debt in current liabilities minus cash and short-term securities, normalized by total market value of firm assets) lagged by two years from the base year. Long-term Leverage is the firm long-term debt normalized by total firm assets, and lagged by two years from the base year. Interest Expense/Assets is the firm interest and related expense normalized by total firm assets, and lagged by two years from the base year. Establishment controls include establishment size and average worker wage. Firm controls are firm age, diversification, and the following financial variables lagged by one year: sales growth, return on assets, investments, R\&D expenses, Tobin's Q, firm size, asset tangibility, and cash holdings. Detailed variable definitions are in the Appendix A. Standard errors are clustered at the SIC-3 code industry-level and are in parentheses. ${ }^{*},{ }^{* *}$, and ${ }^{* * *}$ denote significance at the $10 \%$, $5 \%$, and $1 \%$ levels.

\begin{tabular}{|c|c|c|c|c|c|c|c|c|}
\hline \multirow[t]{2}{*}{ Dependent Variable: } & \multicolumn{8}{|c|}{ Pct Entrepreneurs } \\
\hline & [1] & [2] & [3] & [4] & [5] & [6] & [7] & [8] \\
\hline Market Leverage & $\begin{array}{l}-0.111 \\
(0.164)\end{array}$ & $\begin{array}{l}-0.049 \\
(0.169)\end{array}$ & & & & & & \\
\hline Market Leverage $\times$ IndDistress & $\begin{array}{l}1.090 * * \\
(0.457)\end{array}$ & $\begin{array}{c}1.085 * * \\
(0.445)\end{array}$ & & & & & & \\
\hline Net Leverage & & & $\begin{array}{l}-0.141 \\
(0.164)\end{array}$ & $\begin{array}{l}-0.117 \\
(0.170)\end{array}$ & & & & \\
\hline Net Leverage $\times$ IndDistress & & & $\begin{array}{c}1.214 * * * \\
(0.286)\end{array}$ & $\begin{array}{c}1.220 * * * \\
(0.279)\end{array}$ & & & & \\
\hline Long-term Leverage & & & & & $\begin{array}{l}-0.136 \\
(0.203)\end{array}$ & $\begin{array}{l}-0.090 \\
(0.209)\end{array}$ & & \\
\hline Long-term Leverage $\times$ IndDistress & & & & & $\begin{array}{c}1.993 * * * \\
(0.536)\end{array}$ & $\begin{array}{c}1.996 * * * \\
(0.529)\end{array}$ & & \\
\hline Interest Expense/Assets & & & & & & & $\begin{array}{l}-1.641 \\
(1.661)\end{array}$ & $\begin{array}{l}-1.457 \\
(1.757)\end{array}$ \\
\hline Interest Expense/Assets $\times$ IndDistress & & & & & & & $\begin{array}{c}24.800^{* * *} \\
(10.727)\end{array}$ & $\begin{array}{r}24.796 * * \\
(10.681)\end{array}$ \\
\hline Industry-Year FE & Yes & Yes & Yes & Yes & Yes & Yes & Yes & Yes \\
\hline State-Year FE & Yes & Yes & Yes & Yes & Yes & Yes & Yes & Yes \\
\hline Establishment FE & Yes & Yes & Yes & Yes & Yes & Yes & Yes & Yes \\
\hline Establishment Controls & & Yes & & Yes & & Yes & & Yes \\
\hline Firm Controls & & Yes & & Yes & & Yes & & Yes \\
\hline R-squared & 0.520 & 0.520 & 0.520 & 0.520 & 0.520 & 0.520 & 0.520 & 0.521 \\
\hline Number of Observations & 91,100 & 91,100 & 91,100 & 91,100 & 91,100 & 91,100 & 91,100 & 91,100 \\
\hline
\end{tabular}


Table A.7: The Effect of Firm Financial Distress on the Quality of Entrepreneurs: Report All Controls

This table presents entrepreneur-level analysis. Detailed variable definitions are in the Appendix A. Standard errors are clustered at the SIC-3 code industry-level and are in parentheses. ${ }^{*},{ }^{* *}$, and ${ }^{* * *}$ denote significance at the $10 \%$, $5 \%$, and $1 \%$ levels.

\begin{tabular}{|c|c|c|c|c|c|c|}
\hline \multirow[t]{2}{*}{ Dependent Variable: } & \multicolumn{2}{|c|}{ Worker Ex Ante Earnings } & \multicolumn{2}{|c|}{ Worker Ex Post Earnings } & \multicolumn{2}{|c|}{ Worker Earnings Growth } \\
\hline & [1] & [2] & [3] & [4] & [5] & [6] \\
\hline Leverage & $\begin{array}{c}0.056 \\
(0.094)\end{array}$ & $\begin{array}{c}0.038 \\
(0.029)\end{array}$ & $\begin{array}{l}-0.032 \\
(0.032)\end{array}$ & $\begin{array}{l}-0.037 \\
(0.025)\end{array}$ & $\begin{array}{l}-0.033 \\
(0.031)\end{array}$ & $\begin{array}{l}-0.041^{*} \\
(0.024)\end{array}$ \\
\hline Leverage $\times$ IndDistress & $\begin{array}{c}0.862 * * \\
(0.413)\end{array}$ & $\begin{array}{c}0.481 * * * \\
(0.088)\end{array}$ & $\begin{array}{c}0.225^{* *} \\
(0.110)\end{array}$ & $\begin{array}{c}0.139^{* *} \\
(0.059)\end{array}$ & $\begin{array}{c}0.241 * * \\
(0.108)\end{array}$ & $\begin{array}{c}0.151^{* *} \\
(0.061)\end{array}$ \\
\hline Worker Age & $\begin{array}{c}0.117 * * * \\
(0.009)\end{array}$ & $\begin{array}{c}0.105 * * * \\
(0.008)\end{array}$ & $\begin{array}{c}0.027 * * * \\
(0.006)\end{array}$ & $\begin{array}{c}0.027 * * * \\
(0.005)\end{array}$ & $\begin{array}{c}0.025 * * * \\
(0.006)\end{array}$ & $\begin{array}{c}0.024 * * * \\
(0.005)\end{array}$ \\
\hline Worker Age Squared & $\begin{array}{c}-0.001 * * * \\
(0.000)\end{array}$ & $\begin{array}{c}-0.001 * * * \\
(0.000)\end{array}$ & $\begin{array}{c}-0.000 * * * \\
(0.000)\end{array}$ & $\begin{array}{c}-0.000 * * * \\
(0.000)\end{array}$ & $\begin{array}{c}-0.000^{* * *} * \\
(0.000)\end{array}$ & $\begin{array}{c}-0.000 * * * \\
(0.000)\end{array}$ \\
\hline Worker Female & $\begin{array}{c}-0.252^{* * * *} \\
(0.062)\end{array}$ & $\begin{array}{c}-0.241 * * * \\
(0.035)\end{array}$ & $\begin{array}{c}-0.268 * * * \\
(0.031)\end{array}$ & $\begin{array}{c}-0.270 * * * \\
(0.026)\end{array}$ & $\begin{array}{c}-0.263 * * * \\
(0.030)\end{array}$ & $\begin{array}{c}-0.265 * * * \\
(0.025)\end{array}$ \\
\hline Worker White & $\begin{array}{c}0.190 * * * \\
(0.035)\end{array}$ & $\begin{array}{c}0.154^{* * * *} \\
(0.019)\end{array}$ & $\begin{array}{c}0.112 * * * \\
(0.011)\end{array}$ & $\begin{array}{c}0.106^{* * * *} \\
(0.011)\end{array}$ & $\begin{array}{c}0.110^{* * * *} \\
(0.011)\end{array}$ & $\begin{array}{c}0.104 * * * \\
(0.010)\end{array}$ \\
\hline Worker Foreign Born & $\begin{array}{c}0.046 \\
(0.049)\end{array}$ & $\begin{array}{c}0.005 \\
(0.029)\end{array}$ & $\begin{array}{c}-0.013 \\
(0.020)\end{array}$ & $\begin{array}{l}-0.020 \\
(0.018)\end{array}$ & $\begin{array}{l}-0.013 \\
(0.019)\end{array}$ & $\begin{array}{l}-0.020 \\
(0.018)\end{array}$ \\
\hline Worker In-State Born & $\begin{array}{c}-0.100^{* * * *} \\
(0.013)\end{array}$ & $\begin{array}{c}-0.078 * * * \\
(0.011)\end{array}$ & $\begin{array}{c}-0.027 * * * \\
(0.007)\end{array}$ & $\begin{array}{c}-0.023 * * * \\
(0.006)\end{array}$ & $\begin{array}{c}-0.026 * * * \\
(0.007)\end{array}$ & $\begin{array}{c}-0.023 * * * \\
(0.007)\end{array}$ \\
\hline Worker Education & $\begin{array}{c}0.045^{* * * *} \\
(0.004)\end{array}$ & $\begin{array}{c}0.035^{* * * *} \\
(0.002)\end{array}$ & $\begin{array}{c}0.018 * * * \\
(0.001)\end{array}$ & $\begin{array}{c}0.017 * * * \\
(0.001)\end{array}$ & $\begin{array}{c}0.017 * * * \\
(0.001)\end{array}$ & $\begin{array}{c}0.017 * * * \\
(0.001)\end{array}$ \\
\hline Worker Total Experience & $\begin{array}{c}-0.005^{* *} \\
(0.002)\end{array}$ & $\begin{array}{c}-0.006^{* * * *} \\
(0.002)\end{array}$ & $\begin{array}{c}0.017 * * * \\
(0.002)\end{array}$ & $\begin{array}{c}0.016^{* * * *} \\
(0.002)\end{array}$ & $\begin{array}{c}0.017^{* * * *} \\
(0.002)\end{array}$ & $\begin{array}{c}0.017 * * * * \\
(0.002)\end{array}$ \\
\hline Worker Tenure & $\begin{array}{c}0.170 * * * \\
(0.013)\end{array}$ & $\begin{array}{c}0.153^{* * * *} \\
(0.014)\end{array}$ & $\begin{array}{l}-0.004 \\
(0.005)\end{array}$ & $\begin{array}{c}-0.004 \\
(0.005)\end{array}$ & $\begin{array}{c}-0.004 \\
(0.005)\end{array}$ & $\begin{array}{c}-0.004 \\
(0.005)\end{array}$ \\
\hline Establishment Size & & $\begin{array}{c}-0.063^{* * * *} \\
(0.008)\end{array}$ & & $\begin{array}{c}-0.034 * * * \\
(0.005)\end{array}$ & & $\begin{array}{c}-0.033 * * * \\
(0.005)\end{array}$ \\
\hline Establishment Mean Wage (Excl. Worker) & & $\begin{array}{c}0.869 * * * \\
(0.078)\end{array}$ & & $\begin{array}{c}0.147 * * * \\
(0.030)\end{array}$ & & $\begin{array}{c}0.144 * * * \\
(0.030)\end{array}$ \\
\hline Firm Age & & $\begin{array}{c}0.001 \\
(0.004)\end{array}$ & & $\begin{array}{l}-0.000 \\
(0.002)\end{array}$ & & $\begin{array}{l}-0.000 \\
(0.002)\end{array}$ \\
\hline Diversified Firm & & $\begin{array}{l}-0.059^{*} \\
(0.034)\end{array}$ & & $\begin{array}{c}-0.045^{* * *} \\
(0.017)\end{array}$ & & $\begin{array}{c}-0.049 \text { *** } \\
(0.018)\end{array}$ \\
\hline Firm Sales Growth & & $\begin{array}{c}0.091 * * * \\
(0.025)\end{array}$ & & $\begin{array}{c}-0.018^{* *} \\
(0.009)\end{array}$ & & $\begin{array}{c}-0.018^{* *} \\
(0.008)\end{array}$ \\
\hline Firm Return on Assets & & $\begin{array}{l}-0.090 \\
(0.067)\end{array}$ & & $\begin{array}{l}-0.097^{*} \\
(0.054)\end{array}$ & & $\begin{array}{l}-0.103^{*} \\
(0.054)\end{array}$ \\
\hline Firm Investments & & $\begin{array}{l}0.133^{*} \\
(0.077)\end{array}$ & & $\begin{array}{c}0.240 * * * \\
(0.070)\end{array}$ & & $\begin{array}{c}0.240^{* * * *} \\
(0.071)\end{array}$ \\
\hline Firm R\&D & & $\begin{array}{l}-0.084 \\
(0.161)\end{array}$ & & $\begin{array}{c}0.168 \\
(0.262)\end{array}$ & & $\begin{array}{c}0.068 \\
(0.269)\end{array}$ \\
\hline Firm Tobin's Q & & $\begin{array}{c}0.010 \\
(0.013)\end{array}$ & & $\begin{array}{c}0.004 \\
(0.011)\end{array}$ & & $\begin{array}{c}0.006 \\
(0.011)\end{array}$ \\
\hline Firm Size & & $\begin{array}{c}0.001 \\
(0.006)\end{array}$ & & $\begin{array}{l}-0.005 \\
(0.005)\end{array}$ & & $\begin{array}{l}-0.005 \\
(0.005)\end{array}$ \\
\hline Firm Asset Tangibility & & $\begin{array}{l}-0.074 \\
(0.062)\end{array}$ & & $\begin{array}{c}-0.080^{*} \\
(0.041)\end{array}$ & & $\begin{array}{l}-0.075^{*} \\
(0.039)\end{array}$ \\
\hline Firm Cash & & $\begin{array}{c}0.005 \\
(0.077)\end{array}$ & & $\begin{array}{l}-0.029 \\
(0.044)\end{array}$ & & $\begin{array}{l}-0.049 \\
(0.056)\end{array}$ \\
\hline Worker Ex Ante Earnings & & & $\begin{array}{c}0.332 * * * \\
(0.013)\end{array}$ & $\begin{array}{c}0.316 * * * \\
(0.010)\end{array}$ & $\begin{array}{c}-0.660^{* * * *} \\
(0.013)\end{array}$ & $\begin{array}{c}-0.676^{* * * *} \\
(0.011)\end{array}$ \\
\hline $\begin{array}{l}\text { Industry-Year FE } \\
\text { State-Year FE }\end{array}$ & $\begin{array}{l}\text { Yes } \\
\text { Yes }\end{array}$ & $\begin{array}{l}\text { Yes } \\
\text { Yes }\end{array}$ & $\begin{array}{l}\text { Yes } \\
\text { Yes }\end{array}$ & $\begin{array}{l}\text { Yes } \\
\text { Yes }\end{array}$ & $\begin{array}{l}\text { Yes } \\
\text { Yes }\end{array}$ & $\begin{array}{l}\text { Yes } \\
\text { Yes }\end{array}$ \\
\hline $\begin{array}{l}\text { R-squared } \\
\text { Number of Observations }\end{array}$ & $\begin{array}{c}0.410 \\
315,200\end{array}$ & $\begin{array}{c}0.458 \\
315,200\end{array}$ & $\begin{array}{c}0.231 \\
315,200\end{array}$ & $\begin{array}{c}0.235 \\
315,200\end{array}$ & $\begin{array}{c}0.393 \\
315,200\end{array}$ & $\begin{array}{c}0.396 \\
315,200\end{array}$ \\
\hline
\end{tabular}




\section{Table A.8: The Effect of Firm Financial Distress on the Quality of Startups: Report All Controls}

This table presents startup-level analysis. Detailed variable definitions are in the Appendix A. Standard errors are clustered at the SIC-3 code industry-level and are in parentheses. ${ }^{*},{ }^{* *}$, and ${ }^{* * *}$ denote significance at the $10 \%, 5 \%$, and $1 \%$ levels.

\begin{tabular}{|c|c|c|c|c|c|c|}
\hline \multirow[t]{2}{*}{ Dependent Variable: } & \multicolumn{2}{|c|}{ Startup Exit } & \multicolumn{2}{|c|}{ Startup Future Empl } & \multicolumn{2}{|c|}{ Startup Empl Growth } \\
\hline & [1] & {$[2]$} & [3] & [4] & {$[5]$} & {$[6]$} \\
\hline Leverage & $\begin{array}{c}0.006 \\
(0.006)\end{array}$ & $\begin{array}{c}0.011 \\
(0.007)\end{array}$ & $\begin{array}{c}0.023 \\
(0.020)\end{array}$ & $\begin{array}{c}0.007 \\
(0.021)\end{array}$ & $\begin{array}{c}0.026 \\
(0.021)\end{array}$ & $\begin{array}{c}0.012 \\
(0.021)\end{array}$ \\
\hline Leverage $\times$ IndDistress & $\begin{array}{c}-0.052 * * \\
(0.024)\end{array}$ & $\begin{array}{l}-0.039 \\
(0.025)\end{array}$ & $\begin{array}{c}0.198 * * * \\
(0.064)\end{array}$ & $\begin{array}{c}0.166^{* * *} \\
(0.067)\end{array}$ & $\begin{array}{c}0.172 * * * \\
(0.062)\end{array}$ & $\begin{array}{c}0.143^{* *} \\
(0.064)\end{array}$ \\
\hline Worker Age & $\begin{array}{c}-0.000 \\
(0.001)\end{array}$ & $\begin{array}{l}-0.000 \\
(0.001)\end{array}$ & $\begin{array}{c}0.009 * * * \\
(0.002)\end{array}$ & $\begin{array}{c}0.009 * * * \\
(0.002)\end{array}$ & $\begin{array}{c}0.010^{* * * *} \\
(0.002)\end{array}$ & $\begin{array}{c}0.009^{* * *} * \\
(0.002)\end{array}$ \\
\hline Worker Age Squared & $\begin{array}{c}0.000 \\
(0.000)\end{array}$ & $\begin{array}{c}0.000 \\
(0.000)\end{array}$ & $\begin{array}{c}-0.000 * * * \\
(0.000)\end{array}$ & $\begin{array}{c}-0.000 * * * \\
(0.000)\end{array}$ & $\begin{array}{c}-0.000 * * * \\
(0.000)\end{array}$ & $\begin{array}{c}-0.000^{* * * *} \\
(0.000)\end{array}$ \\
\hline Worker Female & $\begin{array}{c}-0.017 * * * \\
(0.003)\end{array}$ & $\begin{array}{c}-0.016 * * * \\
(0.003)\end{array}$ & $\begin{array}{c}0.011 \\
(0.012)\end{array}$ & $\begin{array}{c}0.011 \\
(0.012)\end{array}$ & $\begin{array}{c}0.006 \\
(0.011)\end{array}$ & $\begin{array}{c}0.006 \\
(0.012)\end{array}$ \\
\hline Worker White & $\begin{array}{c}-0.031 * * * \\
(0.003)\end{array}$ & $\begin{array}{c}-0.031 * * * * \\
(0.003)\end{array}$ & $\begin{array}{c}0.025 * * * \\
(0.008)\end{array}$ & $\begin{array}{c}0.024 * * * * \\
(0.008)\end{array}$ & $\begin{array}{c}0.022 * * * \\
(0.008)\end{array}$ & $\begin{array}{c}0.021^{* * * *} \\
(0.008)\end{array}$ \\
\hline Worker Foreign Born & $\begin{array}{c}-0.041 * * * \\
(0.007)\end{array}$ & $\begin{array}{c}-0.040 * * * \\
(0.008)\end{array}$ & $\begin{array}{c}-0.022 \\
(0.014)\end{array}$ & $\begin{array}{c}-0.022 \\
(0.014)\end{array}$ & $\begin{array}{c}-0.028^{*} \\
(0.014)\end{array}$ & $\begin{array}{c}-0.027 * * \\
(0.014)\end{array}$ \\
\hline Worker In-State Born & $\begin{array}{c}-0.002 \\
(0.003)\end{array}$ & $\begin{array}{c}-0.002 \\
(0.002)\end{array}$ & $\begin{array}{c}-0.020 * * \\
(0.008)\end{array}$ & $\begin{array}{c}-0.020^{* *} \\
(0.008)\end{array}$ & $\begin{array}{c}-0.019^{* *} \\
(0.007)\end{array}$ & $\begin{array}{c}-0.019 * * \\
(0.007)\end{array}$ \\
\hline Worker Education & $\begin{array}{c}-0.001 \\
(0.000)\end{array}$ & $\begin{array}{l}-0.000 \\
(0.000)\end{array}$ & $\begin{array}{c}0.005 * * * \\
(0.001)\end{array}$ & $\begin{array}{c}0.005^{* * *} \\
(0.001)\end{array}$ & $\begin{array}{c}0.004 * * * \\
(0.001)\end{array}$ & $\begin{array}{c}0.004 * * * \\
(0.001)\end{array}$ \\
\hline Worker Total Experience & $\begin{array}{c}0.000 \\
(0.000)\end{array}$ & $\begin{array}{c}0.000 \\
(0.000)\end{array}$ & $\begin{array}{c}0.003^{* *} * \\
(0.001)\end{array}$ & $\begin{array}{c}0.003 * * \\
(0.001)\end{array}$ & $\begin{array}{c}0.003^{* * *} \\
(0.001)\end{array}$ & $\begin{array}{c}0.003^{* *} \\
(0.001)\end{array}$ \\
\hline Worker Tenure & $\begin{array}{c}-0.004 * * * \\
(0.001)\end{array}$ & $\begin{array}{c}-0.005 * * * \\
(0.001)\end{array}$ & $\begin{array}{l}0.005^{*} \\
(0.003)\end{array}$ & $\begin{array}{c}0.006^{* * *} \\
(0.003)\end{array}$ & $\begin{array}{c}0.004 \\
(0.003)\end{array}$ & $\begin{array}{c}0.005^{* *} \\
(0.003)\end{array}$ \\
\hline Worker Ex Ante Earnings & $\begin{array}{c}-0.013 * * * \\
(0.002)\end{array}$ & $\begin{array}{c}-0.012 * * * \\
(0.002)\end{array}$ & $\begin{array}{c}0.087 * * * \\
(0.008)\end{array}$ & $\begin{array}{c}0.088^{* * * *} \\
(0.007)\end{array}$ & $\begin{array}{c}0.083^{* * * *} \\
(0.007)\end{array}$ & $\begin{array}{c}0.084 * * * \\
(0.007)\end{array}$ \\
\hline Startup Age at Joining & $\begin{array}{c}-0.044 * * * \\
(0.001)\end{array}$ & $\begin{array}{c}-0.044 * * * \\
(0.001)\end{array}$ & $\begin{array}{c}0.160 * * * \\
(0.005)\end{array}$ & $\begin{array}{c}0.160 * * * \\
(0.005)\end{array}$ & $\begin{array}{c}0.146 * * * \\
(0.004)\end{array}$ & $\begin{array}{c}0.145^{* * * *} \\
(0.004)\end{array}$ \\
\hline Startup Initial Empl & $\begin{array}{c}-0.015 * * * \\
(0.002)\end{array}$ & $\begin{array}{c}-0.015^{* * * *} \\
(0.002)\end{array}$ & $\begin{array}{c}0.180 * * * \\
(0.009)\end{array}$ & $\begin{array}{c}0.180 * * * \\
(0.009)\end{array}$ & $\begin{array}{c}-0.327 * * * \\
(0.006)\end{array}$ & $\begin{array}{c}-0.327 * * * \\
(0.006)\end{array}$ \\
\hline Establishment Size & & $\begin{array}{l}0.002 * \\
(0.001)\end{array}$ & & $\begin{array}{c}-0.016 * * * \\
(0.004)\end{array}$ & & $\begin{array}{c}-0.015^{* * * *} \\
(0.004)\end{array}$ \\
\hline Establishment Mean Wage (Excl. Worker) & & $\begin{array}{c}-0.010 * * * \\
(0.003)\end{array}$ & & $\begin{array}{c}-0.015 \\
(0.014)\end{array}$ & & $\begin{array}{l}-0.019 \\
(0.013)\end{array}$ \\
\hline Firm Age & & $\begin{array}{c}-0.001 * * * \\
(0.000)\end{array}$ & & $\begin{array}{c}0.001 \\
(0.001)\end{array}$ & & $\begin{array}{c}0.001 \\
(0.001)\end{array}$ \\
\hline Diversified Firm & & $\begin{array}{c}-0.001 \\
(0.007)\end{array}$ & & $\begin{array}{c}-0.002 \\
(0.020)\end{array}$ & & $\begin{array}{c}0.001 \\
(0.019)\end{array}$ \\
\hline Firm Sales Growth & & $\begin{array}{l}-0.007 \\
(0.006)\end{array}$ & & $\begin{array}{c}0.023 \\
(0.015)\end{array}$ & & $\begin{array}{c}0.029 * * \\
(0.013)\end{array}$ \\
\hline Firm Return on Assets & & $\begin{array}{c}0.011 \\
(0.015)\end{array}$ & & $\begin{array}{l}-0.078^{*} \\
(0.044)\end{array}$ & & $\begin{array}{c}-0.077^{*} \\
(0.045)\end{array}$ \\
\hline Firm Investments & & $\begin{array}{l}0.027^{*} \\
(0.016)\end{array}$ & & $\begin{array}{c}0.047 \\
(0.055)\end{array}$ & & $\begin{array}{c}0.057 \\
(0.056)\end{array}$ \\
\hline Firm R\&D & & $\begin{array}{c}0.165 * * * \\
(0.051)\end{array}$ & & $\begin{array}{l}-0.043 \\
(0.204)\end{array}$ & & $\begin{array}{c}-0.000 \\
(0.189)\end{array}$ \\
\hline Firm Tobin's Q & & $\begin{array}{l}-0.001 \\
(0.003)\end{array}$ & & $\begin{array}{l}-0.005 \\
(0.011)\end{array}$ & & $\begin{array}{c}-0.006 \\
(0.011)\end{array}$ \\
\hline Firm Size & & $\begin{array}{c}0.003 * * * \\
(0.001)\end{array}$ & & $\begin{array}{c}-0.006^{* * *} \\
(0.003)\end{array}$ & & $\begin{array}{c}-0.005^{* *} \\
(0.003)\end{array}$ \\
\hline Firm Asset Tangibility & & $\begin{array}{l}-0.006 \\
(0.009)\end{array}$ & & $\begin{array}{l}-0.037 \\
(0.024)\end{array}$ & & $\begin{array}{c}-0.034 \\
(0.024)\end{array}$ \\
\hline Firm Cash & & $\begin{array}{c}0.002 \\
(0.023)\end{array}$ & & $\begin{array}{l}-0.049 \\
(0.060)\end{array}$ & & $\begin{array}{l}-0.046 \\
(0.052)\end{array}$ \\
\hline Industry-Year FE & Yes & Yes & Yes & Yes & Yes & Yes \\
\hline State-Year FE & Yes & Yes & Yes & Yes & Yes & Yes \\
\hline R-squared & 0.021 & 0.022 & 0.038 & 0.038 & 0.075 & 0.076 \\
\hline Number of Observations & 315,200 & 315,200 & 315,200 & 315,200 & 315,200 & 315,200 \\
\hline
\end{tabular}




\section{Table A.9: Startup Characteristics as a Function of the Spawning Firm Financial Distress}

This table presents startup-level analysis. The sample consists of start-ups founded by workers who exit establishments of U.S. public firms from 1990 through 2003. Startup Same Ind is an indicator variable equal to one if an SIC-2 industry of the start-up and the spawning establishment is the same. Startup Initial Empl is the natural logarithm of a start-up employment plus one in the first year of the start-up's existence. Detailed variable definitions are in the Appendix A. Standard errors are clustered at the SIC-3 code industry-level and are in parentheses. ${ }^{*},{ }^{* *}$, and ${ }^{* * *}$ denote significance at the $10 \%, 5 \%$, and $1 \%$ levels.

\begin{tabular}{|c|c|c|c|c|}
\hline \multirow[t]{2}{*}{ Dependent Variable: } & \multicolumn{2}{|c|}{ Startup Same Ind } & \multicolumn{2}{|c|}{ Startup Inital Empl } \\
\hline & [1] & [2] & [3] & [4] \\
\hline Leverage & $\begin{array}{c}0.062 * * * \\
(0.022)\end{array}$ & $\begin{array}{c}0.047 * * * \\
(0.017)\end{array}$ & $\begin{array}{c}0.003 \\
(0.010)\end{array}$ & $\begin{array}{c}0.001 \\
(0.011)\end{array}$ \\
\hline Leverage $\times$ IndDistress & $\begin{array}{l}-0.019 \\
(0.025)\end{array}$ & $\begin{array}{l}-0.030 \\
(0.019)\end{array}$ & $\begin{array}{l}-0.046 \\
(0.034)\end{array}$ & $\begin{array}{l}-0.047 \\
(0.033)\end{array}$ \\
\hline Worker Age & & $\begin{array}{c}0.008 * * \\
(0.003)\end{array}$ & & $\begin{array}{c}0.001 \\
(0.001)\end{array}$ \\
\hline Worker Age Squared & & $\begin{array}{c}-0.000 * * \\
(0.000)\end{array}$ & & $\begin{array}{c}-0.000 \\
(0.000)\end{array}$ \\
\hline Worker Female & & $\begin{array}{c}-0.028 * * * * \\
(0.006)\end{array}$ & & $\begin{array}{c}-0.015^{* * * *} \\
(0.002)\end{array}$ \\
\hline Worker White & & $\begin{array}{c}-0.007 \\
(0.007)\end{array}$ & & $\begin{array}{c}-0.018 * * * \\
(0.003)\end{array}$ \\
\hline Worker Foreign Born & & $\begin{array}{c}0.002 \\
(0.015)\end{array}$ & & $\begin{array}{c}-0.035^{* * * *} \\
(0.005)\end{array}$ \\
\hline Worker In-State Born & & $\begin{array}{c}-0.008 * * * \\
(0.003)\end{array}$ & & $\begin{array}{c}-0.006 * * \\
(0.003)\end{array}$ \\
\hline Worker Education & & $\begin{array}{c}0.003 * * * \\
(0.001)\end{array}$ & & $\begin{array}{c}0.001 * * \\
(0.001)\end{array}$ \\
\hline Worker Tenure & & $\begin{array}{c}-0.004 * * * * \\
(0.001)\end{array}$ & & $\begin{array}{l}-0.001 \\
(0.001)\end{array}$ \\
\hline Worker Total Experience & & $\begin{array}{c}0.003 * * \\
(0.001)\end{array}$ & & $\begin{array}{l}-0.001 \\
(0.001)\end{array}$ \\
\hline Worker Ex Ante Earnings & & $\begin{array}{c}0.028 * * * \\
(0.004)\end{array}$ & & $\begin{array}{c}0.010 * * * \\
(0.001)\end{array}$ \\
\hline Establishment Size & & $\begin{array}{c}-0.025 * * * \\
(0.003)\end{array}$ & & $\begin{array}{l}-0.001 \\
(0.001)\end{array}$ \\
\hline Establishment Mean Wage (Excl. Worker) & & $\begin{array}{l}0.022^{*} \\
(0.012)\end{array}$ & & $\begin{array}{l}-0.006 \\
(0.004)\end{array}$ \\
\hline Firm Age & & $\begin{array}{l}-0.000 \\
(0.001)\end{array}$ & & $\begin{array}{c}0.000 \\
(0.000)\end{array}$ \\
\hline Diversified Firm & & $\begin{array}{c}-0.029^{* *} \\
(0.012)\end{array}$ & & $\begin{array}{l}-0.008 \\
(0.009)\end{array}$ \\
\hline Firm Sales Growth & & $\begin{array}{c}0.013 * * \\
(0.006)\end{array}$ & & $\begin{array}{c}-0.002 \\
(0.006)\end{array}$ \\
\hline Firm Return on Assets & & $\begin{array}{c}0.011 \\
(0.028)\end{array}$ & & $\begin{array}{l}-0.017 \\
(0.028)\end{array}$ \\
\hline Firm Investments & & $\begin{array}{c}0.014 \\
(0.025)\end{array}$ & & $\begin{array}{c}0.024 \\
(0.036)\end{array}$ \\
\hline Firm R\&D & & $\begin{array}{c}-0.195^{* *} \\
(0.075)\end{array}$ & & $\begin{array}{l}0.101 * \\
(0.056)\end{array}$ \\
\hline Firm Tobin's Q & & $\begin{array}{l}-0.001 \\
(0.006)\end{array}$ & & $\begin{array}{l}-0.000 \\
(0.004)\end{array}$ \\
\hline Firm Size & & $\begin{array}{c}-0.005^{* * * *} \\
(0.001)\end{array}$ & & $\begin{array}{c}0.001 \\
(0.001)\end{array}$ \\
\hline Firm Asset Tangibility & & $\begin{array}{c}0.001 \\
(0.018)\end{array}$ & & $\begin{array}{l}-0.004 \\
(0.011)\end{array}$ \\
\hline Firm Cash & & $\begin{array}{c}0.030 \\
(0.031)\end{array}$ & & $\begin{array}{l}-0.006 \\
(0.017)\end{array}$ \\
\hline Industry-Year FE & Yes & Yes & Yes & Yes \\
\hline State-Year FE & Yes & Yes & Yes & Yes \\
\hline R-squared & 0.177 & 0.205 & 0.014 & 0.015 \\
\hline Number of Observations & 315,200 & 315,200 & 315,200 & 315,200 \\
\hline
\end{tabular}


Table A.10: The Effect of Firm Financial Distress on the Rate of Worker Entrepreneurship in Low Startup Capital Industries and High Tech Industries

This table presents establishment-level analysis. The sample consists of establishments of U.S. public firms, and extends from 1990 through 2003. The dependent variable Pct Entrepreneurs is the count of an establishment's workers defined as future entrepreneurs two years after the base year (the year during which the distress is defined), normalized by base year establishment employment and expressed in percentage terms; a worker is a future entrepreneur if, two years after the base year, he works at a start-up (a firm founded during or after the base year) and is also one of the top five earners at that start-up. IndDistress is an indicator variable equal to one if an industry-year is in distress. Leverage is the firm book financial leverage ratio (long-term debt plus debt in current liabilities, normalized by total firm assets) lagged by two years from the base year. High Startup Cost Ind is an indicator variable equal to one for establishments in industries with high start-up costs. High Tech Ind is an indicator variable equal to one for establishments in a high-tech industry (Biotech, Computer, Electronics, and Telecom). All columns include leverage and industry distress indicator. Columns [1] - [2] ([3] - [4]) include an indicator variable High Startup Cost Ind (High Tech Ind) and its interactions with leverage and industry distress. Establishment controls include establishment size and average worker wage. Firm controls are firm age, diversification, and the following financial variables lagged by one year: sales growth, return on assets, investments, $R \& D$ expenses, Tobin's $Q$, firm size, asset tangibility, and cash holdings. Detailed variable definitions are in the Appendix A. Standard errors are clustered at the SIC- 3 code industry-level and are in parentheses. ${ }^{*},{ }^{* *}$, and ${ }^{* * *}$ denote significance at the $10 \%, 5 \%$, and $1 \%$ levels.

\begin{tabular}{|c|c|c|c|c|}
\hline \multirow[t]{2}{*}{ Dependent Variable: } & \multicolumn{4}{|c|}{ Pct Entrepreneurs } \\
\hline & {$[1]$} & [2] & {$[3]$} & [4] \\
\hline Leverage $\times$ IndDistress $\times$ Low Startup Cost Ind & $\begin{array}{c}2.120 * * * \\
(0.649)\end{array}$ & $\begin{array}{c}2.118 * * * \\
(0.649)\end{array}$ & & \\
\hline Leverage $\times$ IndDistress $\times$ High Startup Cost Ind & $\begin{array}{c}1.243 \\
(0.876)\end{array}$ & $\begin{array}{c}1.268 \\
(0.864)\end{array}$ & & \\
\hline Leverage $\times$ IndDistress $\times$ Non-High Tech Ind & & & $\begin{array}{l}1.594 * * \\
(0.625)\end{array}$ & $\begin{array}{c}1.623 * * * \\
(0.614)\end{array}$ \\
\hline Leverage $\times$ IndDistress $\times$ High Tech Ind & & & $\begin{array}{l}2.203 * * * \\
(0.842)\end{array}$ & $\begin{array}{r}2.183^{* *} \\
(0.853)\end{array}$ \\
\hline Industry-Year FE & Yes & Yes & Yes & Yes \\
\hline State-Year FE & Yes & Yes & Yes & Yes \\
\hline Establishment FE & Yes & Yes & Yes & Yes \\
\hline Establishment Controls & & Yes & & Yes \\
\hline Firm Controls & & Yes & & Yes \\
\hline $\begin{array}{l}\text { R-squared } \\
\text { Number of Observations }\end{array}$ & $\begin{array}{c}0.520 \\
91,100\end{array}$ & $\begin{array}{c}0.520 \\
91,100\end{array}$ & $\begin{array}{c}0.520 \\
91,100\end{array}$ & $\begin{array}{c}0.520 \\
91,100\end{array}$ \\
\hline $\begin{array}{l}\text { F-test (difference) } \\
\text { p-val (difference) }\end{array}$ & $\begin{array}{l}0.656 \\
0.419\end{array}$ & $\begin{array}{l}0.623 \\
0.431\end{array}$ & $\begin{array}{l}0.340 \\
0.561\end{array}$ & $\begin{array}{l}0.286 \\
0.594\end{array}$ \\
\hline
\end{tabular}




\section{APPENDIX B: VARIABLE DEFINITION}

\section{Establishment-level Variables}

Pct Entrepreneurs - the count of an establishment's workers defined as future entrepreneurs two years after the base year (the year during which distress is defined), normalized by base year establishment employment and expressed in percentage terms; a worker is a future entrepreneur if, two years after the base year, he works at a start-up (a firm founded during or after the base year) and is also one of the top five earners at that start-up. This is the main definition of entrepreneurship used in the paper. Source: LBD and LEHD

Pct Entrepreneurs/Change Employer - the count of an establishment's workers defined as future entrepreneurs according to the main definition, normalized by the number of the establishment's employees who work for a different employer two years after the base year, and expressed in percentage terms. Source: LBD and LEHD

Pct Entrepreneurs/Leave - the count of an establishment's workers defined as future entrepreneurs according to the main definition, normalized by the number of the establishment's employees who work for a different employer or who drop out from the employment sample two years after the base year, and expressed in percentage terms. Source: LBD and LEHD

Pct Main Founder - the count of an establishment's workers who, two years after the base year, work at start-ups and are also the top earners at those start-ups, normalized by base year establishment employment and expressed in percentage terms. Source: LBD and LEHD

Pct Startups - the count of unique start-ups associated with future entrepreneurs defined according to the main definition, normalized by base year establishment employment and expressed in percentage terms. Source: LBD and LEHD

Pct Stay - the percent of an establishment's workers who, two years after the base year, still work at the firm. Source: LBD and LEHD

Pct Move Existing - the percent of an establishment's workers who, two years after the base year, work at a different firm that existed prior to the base year. Source: LBD and LEHD

Pct Drop-out - the percent of an establishment's workers who, two years after the base year, 
drop out from the employment sample. Source: LBD and LEHD

Pct Move Startups - the percent of the establishment's workers who, two years after the base year, work at start-ups. Source: LBD and LEHD

Establishment Size - the natural logarithm of the number of SEIN workers plus one, measured as of the first quarter of the base year to reflect characteristics of the workers in the establishmentworker panel. The variable is winsorized at the 1st and 99th percentiles of its empirical distribution. Source: LEHD

Establishment Mean Wage - the natural logarithm of the ratio of an establishment's payroll to employment, measured as of the first quarter of the base year to reflect characteristics of the workers in the establishment-worker panel. Payroll is quarterly and measured in constant 2014 dollars. The variable is winsorized at the 1st and 99th percentiles of its empirical distribution. Source: LEHD

Establishment Mean Worker Age - the establishment mean worker age, in years. Source:

\section{LEHD}

Establishment Percent Female - the percent of female workers at a given establishment-year. Source: LEHD

Establishment Mean Worker Education - the worker education, averaged at an establishmentyear level. Education is measured in years and imputed in the LEHD database. Source: LEHD

Establishment Mean Worker Tenure - the number of years a worker is at the SEIN, averaged at an establishment-year level. The variable is winsorized at the 1st and 99th percentiles of its empirical distribution. Source: LEHD

Big Industry - an indicator variable equal to one when an establishment belongs to an industry that comprises at least ten percent of the firm total employment. Source: LBD

No Spin-offs - an indicator variable equal to one when less than fifty percent of employees exit to work at start-ups two years after the base year. Source: LBD and LEHD

Establishment Employment Growth - measured over the same period as the main entrepreneurship variable; it is defined in percentage terms and equal to the log-difference between three-year 
future and base year employments, both measured as of the first quarter. Base year is the year during which distress is defined. Source: LEHD

\section{Firm-level Variables}

Leverage - the firm book financial leverage ratio (long-term debt plus debt in current liabilities, normalized by total firm assets) lagged by two years from the base year. It is set to missing if negative and set equal to one if larger than one. Source: Compustat

Firm Age - the age of the oldest establishment that the firm owns in the first year the firm is observed in the LBD (Haltiwanger et al. (2012)). The firm then ages by one year for each additional year it is observed in the data. This definition of firm age is robust to misclassifying an establishment that changes ownership through mergers and acquisitions as a firm birth, since a firm is defined as a new firm only when all the establishments at the firm are new. Since the LBD coverage starts in 1976, firm age is left censored for firms that existed prior to 1976. Source: LBD

Diversified Firm - an indicator variable equal to one when a firm has establishments in more than one SIC-3 industry as of the year in which the industry distress is defined. Source: LBD

Firm Sales Growth - the firm sales growth lagged by one year from the base year. The variable is winsorized at the 1st and 99th percentiles of its empirical distribution. Source: Compustat

Firm Return on Assets - the firm operating income (EDITDA) normalized by total firm assets and lagged by one year from the base year. The variable is winsorized at the 1st and 99th percentiles of its empirical distribution. Source: Compustat

Firm Investments - the firm CAPEX minus property, plant, and equipment sales divided by total firm assets and lagged by one year from the base year. The variable is winsorized at the 1st and 99th percentiles of its empirical distribution. Source: Compustat

Firm R\&D - the firm research and development expenses divided by total firm assets. Research and development expenses are set to zero when missing. The variable is lagged by one year from the base year and winsorized at the 1st and 99th percentiles of its empirical distribution. Source: Compustat and CRSP

Firm Tobin's $Q$ - the firm market value of assets (market value of common equity plus total 
assets minus book value of common equity) divided by the book value of total firm assets. The market value of common equity is the number of common shares times stock price at the end of the fiscal year. The book value of common equity is common equity plus deferred taxes and investment tax credit. It is lagged by one year from the base year and winsorized at the 1 st and 99th percentiles of its empirical distribution. Source: Compustat

Firm Size - the natural logarithm of total firm assets. It is lagged by one year from the base year and winsorized at the 1st and 99th percentiles of its empirical distribution. Source: Compustat

Firm Asset Tangibility - the firm property, plant, and equipment normalized by total firm assets. The variable is lagged by one year from the base year and winsorized at the 1st and 99th percentiles of its empirical distribution. Source: Compustat

Firm Cash - the firm cash and short-term investments divided by total firm assets. The variable is lagged by one year from the base year and winsorized at the 1st and 99th percentiles of its empirical distribution. Source: Compustat

Small (Large) Firm - an indicator variable equal to one for establishments of firms with one year lagged total assets below (above or equal to) the median firm's assets. The sorting is done within each year. Source: Compustat

Young (Old) Firm - an indicator variable equal to one for establishments of firms in Compustat for five years or fewer (more than five years). Source: Compustat

Market Leverage - the firm market financial leverage ratio (long-term debt plus debt in current liabilities, normalized by total market value of firm assets) lagged by two years from the base year. Total market value of firm assets is equal to market value of common equity plus total assets minus book value of common equity. The market value of common equity is the number of common shares times stock price at the end of the fiscal year. The book value of common equity is common equity plus deferred taxes and investment tax credit. The variable is winsorized at the 1st and 99th percentiles of its empirical distribution. Source: Compustat

Net Leverage - the firm net book financial leverage ratio (long-term debt plus debt in current liabilities minus cash and short-term securities, normalized by total market value of firm assets) 
lagged by two years from the base year. The variable is winsorized at the 1st and 99th percentiles of its empirical distribution. Source: Compustat

Long-term Leverage - the firm long-term debt normalized by total firm assets, and lagged by two years from the base year. The variable is winsorized at the 1st and 99th percentiles of its empirical distribution. Source: Compustat

Interest Expense/Assets - the firm interest and related expense normalized by total firm assets, and lagged by two years from the base year. The variable is winsorized at the 1st and 99th percentiles of its empirical distribution. Source: Compustat

Negative (Non-Negative) Oper Income - an indicator variable equal to one for firms with negative (non-negative) operating income (EBITDA) one year prior to the base year. Source: Compustat

\section{Industry-level Variables}

IndDistress - an indicator variable equal to one if an industry-year is in distress and zero otherwise. Please refer to section 2 for detailed explanation. Source: Compustat and CRSP

High Startup Cost Ind - an indicator variable equal to one for establishments in industries with high start-up costs. Two-digit NAICS sector industries are sorted by the average capital amount necessary to start a business. Industries above (below) the median get assigned into high (low) start-up cost industries. The data are from the Survey of Business Owners (SBO) Public Use Microdata Sample (PUMS) using responses to the question about Amount of start-up or acquisition capital for each firm with employees in the 2007 survey year. Source: Adelino, Schoar, and Severino (2015), Table A5 in the internet appendix.

High Tech Ind - is an indicator variable equal to one for establishments in a high-tech industry, which includes Biotech (SIC codes 2830-2839, 3826, 3841-3851, 5047, 5048, 5122, 6324, 7352, 8000-8099, or 8730-8739 excluding 8732); Computer (SIC codes 5370-5379, 5044, 5045, 5734, or 7370-7379); Electronics (SIC codes 3600-3629, 3643, 3644, 3670-3699, 3825, 5065, or 5063); and Telecom (SIC codes 3660-3669 or 4810-4899). Source: Ouimet and Zarutskie (2014), Table 6. 


\section{State-level Variables}

Low (High) Enforceability Non-Competes - an indicator variable equal to one for establishments in states with the Noncompetition Enforceability Index value less than (greater or equal to) 5 , the median value of the index. The index measures how strictly states enforce non-compete agreements, which are contracts between employers and employees that restrict worker postemployment mobility into competing firms. Source: Garmaise (2009)

\section{Worker-level Variables}

Worker Age - the worker age in years. The variable is winsorized at the 1st and 99 th percentiles of its empirical distribution. Source: LEHD

Worker Female - an indicator variable equal to one if a worker is female. Source: LEHD

Worker White - an indicator variable equal to one if a worker is white. Source: LEHD

Worker Foreign Born - an indicator variable equal to one if a worker was born outside of the

\section{U.S. Source: LEHD}

Worker In-State Born - an indicator variable equal to one if a worker was born outside the state of location of the establishment of a public firm. Source: LEHD

Worker Education - the number of years of education. Note: education is imputed in the LEHD database. The variable is winsorized at the 1st and 99th percentiles of its empirical distribution. Source: LEHD

Worker Total Experience - the number of years a worker is in the LEHD. Note: since LEHD coverage starts in 1990, the variable is left censored. The variable is winsorized at the 1st and 99th percentiles of its empirical distribution. Source: LEHD

Worker Tenure - the number of years a worker is at the establishment of a public firm. Note: since the LEHD coverage starts in 1990, the variable is left censored. The variable is winsorized at the 1st and 99th percentiles of its empirical distribution. Source: LEHD

Worker Ex Ante Earnings - the natural logarithm of the real wages earned at a public firm

during the quarter the worker is identified with that firm. Real earnings are in constant 2014 dollars. The variable is winsorized at the 1st and 99th percentiles of its empirical distribution. 


\section{Source: LEHD}

Worker Ex Post Earnings - the natural logarithm of total three-year real wages earned since the worker became identified as an entrepreneur. For example, for the employee at a public firm in the first quarter of 1998 who left and was identified with a start-up in the first quarter of 2001, I sum his real earnings in 2001, 2002, and 2003. Real earnings are in constant 2014 dollars. The variable is winsorized at the 1st and 99th percentiles of its empirical distribution. Source: LEHD

Worker Earnings Growth - the log-difference between ex post and ex ante earnings, where ex ante earnings are calculated similarly to ex post earnings. For example, to calculate ex ante earnings for the employee at a Compustat firm in the first quarter of 1998, I sum his real earnings in 1995, 1996, and 1997. Real earnings are in constant 2014 dollars. The variable is winsorized at the 1st and 99th percentiles of its empirical distribution. Source: LEHD

Establishment Mean Wage (Excl. Worker) - the establishment mean wage calculated for a given worker, and excludes that worker's wage from the calculation of the mean. It is equal to the the natural logarithm of an establishment quarterly real payroll minus the worker real wage divided by the number of workers at the establishment, not counting the worker; measured as of the first quarter of the base year to reflect characteristics of the workers in the establishment-worker panel. Real earnings are in constant 2014 dollars. The variable is winsorized at the 1st and 99th percentiles of its empirical distribution. Source: LEHD

\section{Startup-level Variables}

Startup Age at Joining - the start-up age in years during the year it is identified with the entrepreneur, taking values from one to three, inclusively. Source: LBD

Startup Same Ind - an indicator variable equal to one if an SIC-2 industry of the start-up and the spawning establishment is the same. Source: LBD and LEHD

Startup Initial Empl - the natural logarithm of start-up employment plus one in the first year of the start-up's existence. The variable is winsorized at the 1st and 99th percentiles of its empirical distribution. Source: LBD

Startup Exit - an indicator variable equal to one if a start-up exits by the fifth year since it 
became identified with the entrepreneur. Source: LBD

Startup Future Empl - the natural logarithm of start-up employment plus one in five years since it became identified with the entrepreneur. The variable is winsorized at the 1st and 99th percentiles of its empirical distribution. Source: LBD

Startup Empl Growth - the log-difference between start-up future and initial employment. The variable is winsorized at the 1st and 99th percentiles of its empirical distribution. Source: LBD 


\section{REFERENCES}

Abowd, J. M., B. E. Stephens, L. Vilhuber, F. Andersson, K. L. McKinney, M. Roemer, and S. Woodcock (2009, January). The LEHD infrastructure files and the creation of the quarterly workforce indicators. NBER, 149-230.

Adelino, M., A. Schoar, and F. Severino (2015, August). House prices, collateral, and selfemployment. Journal of Financial Economics 117(2), 288-306.

Agrawal, A. K. and D. A. Matsa (2013, May). Labor unemployment risk and corporate financing decisions. Journal of Financial Economics 108(2), 449-470.

Almeling, D. S., D. W. Snyder, and M. Sapoznikow (2009). Statistical analysis of trade secret litigation in federal courts, a. Gonzaga Law Review 45, 291.

Andrade, G. and S. N. Kaplan (1998). How costly is financial (Not economic) distress? evidence from highly leveraged transactions that became distressed. The Journal of Finance 53(5), 1443-1493.

Anton, J. J. and D. A. Yao (1995, October). Start-ups, spin-offs, and internal projects. Journal of Law, Economics, \& Organization 11(2), 362-378.

Arrow, K. (1962). Economic welfare and the allocation of resources for invention. In The rate and direction of inventive activity: Economic and social factors, pp. 609-626. Princeton University Press.

Asker, J., J. Farre-Mensa, and A. Ljungqvist (2011, March). What do private firms look like? SSRN Scholarly Paper ID 1659926, Social Science Research Network, Rochester, NY.

Babina, T., P. P. Ouimet, and R. Zarutskie (2015). Going entrepreneurial? IPOs and new firm creation. working paper.

Benmelech, E. and N. K. Bergman (2011). Bankruptcy and the collateral channel. The Journal of Finance 66(2), 337-378.

Benmelech, E., N. K. Bergman, and R. J. Enriquez (2012, February). Negotiating with labor under financial distress. Review of Corporate Finance Studies, cfr001.

Berk, J. B., R. Stanton, and J. Zechner (2010). Human capital, bankruptcy, and capital structure. The Journal of Finance 65(3), 891-926.

Bernstein, S. (2015, August). Does going public affect innovation? The Journal of Finance 70(4), 1365-1403.

Bertrand, M., E. Duflo, and S. Mullainathan (2004, February). How much should we trust Differences-In-Differences estimates? The Quarterly Journal of Economics 119(1), 249-275.

Bhide, A. (2000). The Origin and Evolution of New Businesses. Oxford University Press. 
Bjelland, M., B. Fallick, J. Haltiwanger, and E. McEntarfer (2011, October). Employer-toEmployer flows in the united states: Estimates using linked Employer-Employee data. Journal of Business \& Economic Statistics 29(4), 493-505.

Borenstein, S. and N. L. Rose (2003, May). The impact of bankruptcy on airline service levels. The American Economic Review 93(2), 415-419.

Brown, J. and D. A. Matsa (2012, July). Boarding a sinking ship? an investigation of job applications to distressed firms. Working Paper 18208, National Bureau of Economic Research.

Burton, M. D., J. Sorensen, and C. Beckman (2002, January). Coming from good stock: Career histories and new venture formation. Articles and Chapters.

Carnahan, S., R. Agarwal, and B. A. Campbell (2012, December). Heterogeneity in turnover: The effect of relative compensation dispersion of firms on the mobility and entrepreneurship of extreme performers. Strategic Management Journal 33(12), 1411-1430.

Chevalier, J. A. (1995a, June). Capital structure and Product-Market competition: Empirical evidence from the supermarket industry. The American Economic Review 85(3), 415-435.

Chevalier, J. A. (1995b). Do LBO supermarkets charge more? an empirical analysis of the effects of LBOs on supermarket pricing. The Journal of Finance 50(4), 1095-1112.

Chevalier, J. A. and D. S. Scharfstein (1996, September). Capital-Market imperfections and countercyclical markups: Theory and evidence. The American Economic Review 86(4), 703-725.

Chodorow-Reich, G. (2014, February). The employment effects of credit market disruptions: Firm-level evidence from the 2008-9 financial crisis. The Quarterly Journal of Economics 129(1), 1-59.

Davis, S. J. and J. Haltiwanger (2014, September). Labor market fluidity and economic performance. Working Paper 20479, National Bureau of Economic Research.

Decker, R., J. Haltiwanger, R. Jarmin, and J. Miranda (2014). The role of entrepreneurship in US job creation and economic dynamism. The Journal of Economic Perspectives, 3-24.

Dougal, C., C. A. Parsons, and S. Titman (2015, February). Urban vibrancy and corporate growth. The Journal of Finance 70(1), 163-210.

Elfenbein, D. W., B. H. Hamilton, and T. R. Zenger (2010, April). The small firm effect and the entrepreneurial spawning of scientists and engineers. Management Science 56(4), 659-681.

Fairlie, R. W. (2013, April). Kauffman index of entrepreneurial activity 1996-2012. SSRN Scholarly Paper ID 2256032, Social Science Research Network, Rochester, NY.

Fallick, B., C. A. Fleischman, and J. B. Rebitzer (2006, August). Job-Hopping in silicon valley: Some evidence concerning the microfoundations of a High-Technology cluster. Review of 
Economics and Statistics 88(3), 472-481.

Farre-Mensa, J. and A. Ljungqvist (2013, October). Do measures of financial constraints measure financial constraints? Working Paper 19551, National Bureau of Economic Research.

Gans, J. S. and S. Stern (2003, February). The product market and the market for "ideas": commercialization strategies for technology entrepreneurs. Research Policy 32(2), 333-350.

Garmaise, M. J. (2009, November). Ties that truly bind: Noncompetition agreements, executive compensation, and firm investment. Journal of Law, Economics, and Organization.

Giannetti, M. and A. Simonov (2009, September). Social interactions and entrepreneurial activity. Journal of Economics \& Management Strategy 18(3), 665-709.

Gibbons, R. and L. F. Katz (1991, October). Layoffs and lemons. Journal of Labor Economics 9(4), $351-380$.

Giroud, X. and H. M. Mueller (2015, March). Firm leverage and unemployment during the great recession. SSRN Scholarly Paper ID 2588055, Social Science Research Network, Rochester, NY.

Gompers, P., J. Lerner, and D. Scharfstein (2005). Entrepreneurial spawning: Public corporations and the genesis of new ventures, 1986 to 1999. The Journal of Finance 60(2), 577-614.

Gopalan, R. and K. Xie (2011, November). Conglomerates and industry distress. Review of Financial Studies 24(11), 3642-3687.

Graham, J. R. (2000). How big are the tax benefits of debt? The Journal of Finance 55(5), 1901-1941.

Graham, J. R., H. Kim, S. Li, and J. Qiu (2015, October). The reallocative employee costs of corporate bankruptcy. SSRN Scholarly Paper ID 2276753, Social Science Research Network, Rochester, NY.

Gromb, D. and D. Scharfstein (2002, June). Entrepreneurship in equilibrium. Working Paper 9001, National Bureau of Economic Research.

Grossman, S. J. and O. D. Hart (1986, August). The costs and benefits of ownership: A theory of vertical and lateral integration. Journal of Political Economy 94(4), 691-719.

Hadlock, C. J. and J. R. Pierce (2010, May). New evidence on measuring financial constraints: Moving beyond the KZ index. Review of Financial Studies 23(5), 1909-1940.

Haltiwanger, J., R. S. Jarmin, and J. Miranda (2012, May). Who creates jobs? small versus large versus young. Review of Economics and Statistics 95(2), 347-361.

Hamilton, B. H. (2000, June). Does entrepreneurship pay? an empirical analysis of the returns to 
Self-Employment. Journal of Political Economy 108(3), 604-631.

Hart, O. and J. Moore (1990, December). Property rights and the nature of the firm. Journal of Political Economy 98(6), 1119-1158.

Hellmann, T. (2002, May). A theory of strategic venture investing. Journal of Financial Economics 64(2), 285-314.

Hellmann, T. (2007, June). When do employees become entrepreneurs? Management Science 53(6), 919-933.

Hennessy, C. A. and I. A. Strebulaev (2015, February). Natural experiment policy evaluation: A critique. Working Paper 20978, National Bureau of Economic Research.

Holmström, B. (1999, January). Managerial incentive problems: A dynamic perspective. The Review of Economic Studies 66(1), 169-182.

Hortaçsu, A., G. Matvos, C. Syverson, and S. Venkataraman (2013, March). Indirect costs of financial distress in durable goods industries: The case of auto manufacturers. Review of Financial Studies.

Hotchkiss, E. S. (1995, March). Postbankruptcy performance and management turnover. The Journal of Finance 50(1), 3-21.

Jarmin, R. S. and J. Miranda (2002). The longitudinal business database. working paper.

Jauhiainen, T., P. Heilmann, and P. Hurmelinna (2003). Risks related to Recruitment—A survey among SMEs in ICT sector in finland. In Conference Paper Presented in 17th Nordic Conference on Business Studies in Reykjavik, Iceland, Volume 15, pp. 2003.

Kaplan, S. N. and P. Strömberg (2003, April). Financial contracting theory meets the real world: An empirical analysis of venture capital contracts. The Review of Economic Studies 70(2), 281315.

Kerr, S. P., W. R. Kerr, and R. Nanda (2014). House money and entrepreneurship. working paper.

Klepper, S. and S. Sleeper (2005, August). Entry by spinoffs. Management Science 51(8), 12911306.

Kovenock, D. and G. M. Phillips (1997, July). Capital structure and product market behavior: an examination of plant exit and investment decisions. Review of Financial Studies 10(3), 767-803.

Lazear, E. P. (2009, October). Firm-Specific human capital: A Skill-Weights approach. Journal of Political Economy 117(5), 914-940. ArticleType: research-article / Full publication date: October 2009 / Copyright (c) 2009 The University of Chicago Press.

Leland, H. E. and D. H. Pyle (1977). Informational asymmetries, financial structure, and financial 
intermediation. The Journal of Finance 32(2), 371-387.

Lemmon, M. L., M. R. Roberts, and J. F. Zender (2008). Back to the beginning: Persistence and the Cross-Section of corporate capital structure. The Journal of Finance 63(4), 1575-1608.

Li, D. (2011, June). Financial constraints, R\&D investment, and stock returns. Review of Financial Studies, hhr043.

Lucas, Robert E., J. (1978, October). On the size distribution of business firms. The Bell Journal of Economics 9(2), 508-523.

Maksimovic, V. and S. Titman (1991, January). Financial policy and reputation for product quality. Review of Financial Studies 4(1), 175-200.

Marx, M. (2011, October). The firm strikes back non-compete agreements and the mobility of technical professionals. American Sociological Review 76(5), 695-712.

Marx, M., D. Strumsky, and L. Fleming (2009, April). Mobility, skills, and the michigan NonCompete experiment. Management Science 55(6), 875-889.

Matsa, D. A. (2011, February). Running on empty? financial leverage and product quality in the supermarket industry. American Economic Journal: Microeconomics 3(1), 137-173.

Myers, S. C. and N. S. Majluf (1984, June). Corporate financing and investment decisions when firms have information that investors do not have. Journal of Financial Economics 13(2), 187221.

Opler, T. C. and S. Titman (1994, July). Financial distress and corporate performance. The Journal of Finance 49(3), 1015-1040.

Ouimet, P. and R. Zarutskie (2014, June). Who works for startups? the relation between firm age, employee age, and growth. Journal of Financial Economics 112(3), 386-407.

Parker, S. C. (2009, November). The Economics of Entrepreneurship. Cambridge University Press.

Pfeiffer, F. and F. Reize (2000, September). Business start-ups by the unemployed - an econometric analysis based on firm data. Labour Economics 7(5), 629-663.

Phillips, G. and G. Sertsios (2013, August). How do firm financial conditions affect product quality and pricing? Management Science 59(8), 1764-1782.

Phillips, G. M. (1995, February). Increased debt and industry product markets an empirical analysis. Journal of Financial Economics 37(2), 189-238.

Pulvino, T. C. (1998). Do asset fire sales exist? an empirical investigation of commercial aircraft transactions. The Journal of Finance 53(3), 939-978. 
Robb, A. and E. J. Reedy (2012, May). An overview of the kauffman firm survey: Results from 2010 business activities. SSRN Scholarly Paper ID 2055265, Social Science Research Network, Rochester, NY.

Robb, A. M. and D. T. Robinson (2014, January). The capital structure decisions of new firms. Review of Financial Studies 27(1), 153-179.

Robinson, D. T. (2008, April). Strategic alliances and the boundaries of the firm. Review of Financial Studies 21(2), 649-681.

Rose, N. L. (1990, October). Profitability and product quality: Economic determinants of airline safety performance. Journal of Political Economy 98(5), 944-964.

Samila, S. and O. Sorenson (2011, January). Noncompete covenants: Incentives to innovate or impediments to growth. Management Science 57(3), 425-438.

Schmalz, M. C., D. A. Sraer, and D. Thesmar (2013). Housing collateral and entrepreneurship. Technical report, National Bureau of Economic Research.

Seru, A. (2014, February). Firm boundaries matter: Evidence from conglomerates and R\&D activity. Journal of Financial Economics 111(2), 381-405.

Shane, S. and S. Venkataraman (2000, January). The promise of entrepreneurship as a field of research. Academy of Management Review 25(1), 217-226.

Stevens, D. W. (2007). Employment that is not covered by state unemployment insurance laws. Technical report, Center for Economic Studies, US Census Bureau.

Stuart, T. and O. Sorenson (2003, February). The geography of opportunity: spatial heterogeneity in founding rates and the performance of biotechnology firms. Research Policy 32(2), 229-253.

Titman, S. (1984, March). The effect of capital structure on a firm's liquidation decision. Journal of Financial Economics 13(1), 137-151.

Williamson, O. E. (1975). Markets and hierarchies: antitrust analysis and implications. New York: The Free Pres.

Zingales, L. (1998). Survival of the fittest or the fattest? exit and financing in the trucking industry. The Journal of Finance 53(3), 905-938. 